\title{
Improved parameterization of the weathering kinetics module in the PROFILE and ForSAFE models
}

\author{
Harald Ulrik Sverdrup ${ }^{1,8^{*}}$, Eric H. Oelkers ${ }^{2,3}$ Martin Erlandsson Lampa ${ }^{4}$, \\ Salim Belyazid ${ }^{5}$, Daniel Kurz ${ }^{6}$, Cecilia Akselsson ${ }^{7}$
}

1- System Dynamics, Department of Gamification, Inland Norway University of Applied Sciences, NO- 2318, Hamar, Norway, 2-Earth Sciences, University College London, WC1E 6BT, London, UK, 3-CNRS, UMR5563, Toulouse, France, 4-Institute of Hydrology, University of Uppsala, SE-751 05 Uppsala, Sweden, 5Physical Geography, Stockholm University, SE-106 91 Stockholm, Sweden, 6-EKG Geoscience, CH-3012 Bern, Switzerland, 7-Earth Sciences, University of Lund, SE-221 00 Lund, Sweden. 8-Industrial Engineering, University of Iceland, IS-107 Reykjavik, Icleand. *corresponding author (harald.sverdrup@inn.no)

\begin{abstract}
Although the PROFILE and ForSAFE model can accurately reproduce the chemical and mineralogical evolution of the soil unsaturated zone, it overestimates weathering rates in deeper soil layers and in groundwater systems. This overestimation has been corrected by improving the kinetic expression describing mineral dissolution by adding or upgrading 'braking functions'. The base cation and aluminium brakes have been strengthened, and an additional silicate brake has been developed, improving the ability to describe mineral-water reactions in deeper soils. These brakes are developed from a molecular-level model of the dissolution mechanisms. Equations, parameters and constants describing mineral dissolution kinetics have now been obtained for 113 minerals from 12 major structural groups, comprising all types of minerals encountered in most soils. The PROFILE and ForSAFE weathering sub-model was extended to cover two-dimensional catchments, both in the vertical and the horizontal direction, including the hydrology. Comparisons between this improved model and field observations are available in Erlandsson Lampa et al. (2019, This special issue). The results showed that the incorporation of a braking effect of silica concentrations was necessary and helps obtain more accurate descriptions of soil evolution rates at greater depths and within the saturated zone.
\end{abstract}

\section{Introduction}

This manuscript reviews the chemical weathering approach adopted by the PROFILE and ForSAFE models and describes continuing efforts to upgrade the kinetic databases of these models for improved model calculations. The application of mineral dissolution kinetics to natural systems requires a large amount of field input including information on mineral surface areas, mineral abundances over time and their spatial distribution, fluid flow and biotic activity. As such this manuscript will by design describe both the weathering models and the evaluation of laboratory mineral dissolution rate used in the development of the upgraded kinetic database.

Chemical weathering of silicate minerals, and notably the dissolution rates of these minerals are one of the most important factors shaping soil chemistry. The quality of the kinetic database in most cases determines the quality of its simulations of soil evolution. In the 1980's, the need arose to mitigate acid deposition, to set critical loads for acid deposition, and to set limits for sustainable forest growth and nitrogen critical loads. This need led to a re-evaluation of the weathering observations available in scientific publications and books (Sverdrup 1990, Sverdrup and Warfvinge 1992, 1993, 1995, Drever et al., 1994, Drever and Clow 1995, Ganor et al., 2005, Svoboda-Colberg and Drever 1993, Crundwell 2013). These observations led to a model that accurately reproduced weathering rates under field conditions. The early history of these efforts was reported by Sverdrup and Warfvinge (1988a,b, 1992, 1993, 1995) and Sverdrup (1990). By 1990, we had a set of equations that described the dissolution rates of 14 minerals (K-feldpar, albite, plagioclase, pyroxene, hornblende, garnet, epidote, chlorite, biotite, muscovite, vermiculite, apatite, kaolinite, and calcite). Later more silicate minerals were added, including illite, smectite, montmorillonite, sericite and volcanic glass. Eventually we amassed kinetic data for 45 additional silicate minerals and 25 different carbonates ${ }^{1}$ at the time.

${ }^{1}$ Calcite (The calcites are all slightly different; $\mathrm{CaCO}_{3}$ with $0-3 \% \mathrm{MgCO}_{3}$ and $0.05 \%-0.5 \%$ apatite, from Sweden, Norway, Denmark, and the United States. In addition, kinetics on aragonite $\left(\mathrm{CaCO}_{3}\right)$, slavsonite $\left(\mathrm{SrCO}_{3}\right)$, dolomite $\left(\mathrm{CaMg}\left(\mathrm{CO}_{3}\right)_{2}\right.$, magnesite $\left(\mathrm{MgCO}_{3}\right)$, brucite $(\mathrm{MgOH})$, siderite $\left(\mathrm{FeCO}_{3}\right)$, witherite $\left(\mathrm{BaCO}_{3}\right)$, and rhodochroisite $\left(\mathrm{MnCO}_{3}\right)$ is available. 
By the middle of the 1980's, it became clear that we did not have a standard procedure for building a weathering rate model based on molecular level mechanisms. There are many reasons for this, the most important was the lack of a mechanistically oriented approach for guiding experimental studies. The lack of a mechanistic understanding resulted in important factors being overlooked. Many essential variables required for a weathering model were missing in the older experimental studies, sample preparation was often inadequate or not done, and/or the material was inadequately characterized (Sverdrup et al., 1981, 1984, Sverdrup, 1990). Often the experimental design had significant flaws and many experiments ran for too short a time; see Sverdrup (1990) for a full description. As such there needed to be a sorting of the data, to avoid the confusion brought by misleading data. This effort led to the creation of the original PROFILE mineral kinetic weathering model (Sverdrup, 1990) to estimate the rate at which mineral dissolution provided essential cations to soil waters. Although this model provides accurate estimates for shallow soils, it became less accurate for deeper soils (e.g. $>1.5$ meter soil depth).

This report outlines our efforts to update these early mineral weathering kinetics models for accurate predictions of watershed water and deeper groundwater chemistry. This effort builds upon the weathering book by Sverdrup (1990) and the articles Sverdrup and Warfvinge (1988a,b, 1992, 1995) and Warfvinge and Sverdrup (1993). There is an advisory chapter on how to estimate weathering rates in soils on a regional scale in Europe in the United Nations Economic Commission for Europe, Long Range Transboundary Convention Mapping Manual for Critical loads (Sverdrup, 1996). The weathering rate mapping methodology based on PROFILE model predictions was tested and used throughout 26 different European countries, and peer reviewed at annual workshops from 1988 to 2017.

The revision of the original PROFILE weathering rate models described in this report was motivated by several observations:

1. The PROFILE model was found to work satisfactorily in the unsaturated zone (0-1 meter), on thin soils, on rock surfaces, and in low concentration systems (Sverdrup and Warfvinge 1988a,b, 1991, 1992, 1993, 1995, 1998, Sverdrup 1990, Sverdrup et al., 1998, Hettelingh et al., 1992, Alveteg et al., 1996, 1998, 2000, Alveteg and Sverdrup 2000).

2. However, the chemical weathering rate for minerals is overestimated by this model in deeper soils, and at depths of more than 1.5 meters. The original PROFILE model was used down to this depth (Sverdrup et al., 1988a,b, 1992, 1996, Sverdrup 1990, Janicki et al., 1993, Holmqvist et al., 2003) for critical loads for streams (Sverdrup et al., 1996) and groundwater (Warfvinge et al., 1987), and may have possibly resulted in overestimates of the critical load.

3. The weathering rate is overestimated in the deeper soils and in ground water (Sverdrup 1990, Warfvinge and Sverdrup 1987, 1992a,b,c, Sverdrup et al., 1996).

4. New experimental data published in the literature after 1995 is of far better quality and consistency, with better experimental designs, better characterized materials and more complete observations than previous studies. For example, the reader is encouraged to read two studies published by Holmqvist et al., $(2002,2003)$ on the weathering rates of clay minerals under soil conditions and the concept of mineral alteration sequences (Holmqvist 2004, PhD thesis from Chemical Engineering, Lund University). The minerals used in the weathering rate experiments in those studies were extracted and separated from in-situ soils at experimental field sites near Uppsala, Sweden.

This study describes the updated mineral kinetics database used in the PROFILE and ForSAFE models, Notably this update includes revised 'brake functions' in the kinetic rate equations to better fit the observed field data down to the groundwater table and below. This was necessitated when the ForSAFE model (thus also the PROFILE model) was reconfigured for a sloping catchment, expanding the model structure from a 1-dimensional to a 2-dimensional model accounting for vertical and horizontal solute transport in a catchment, including the ecosystem. In total 102 minerals are considered in the updated and expanded kinetics parameter databases. An exhaustive description of the parameterization of the rate equations for all of the 102 minerals will require a text far beyond what is possible in this manuscript, so that only a summary and several examples are provided here. 
The arrow shows a causality. A variable at the tail causes a change to the variable at the head of the arrow.

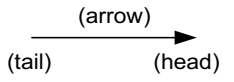

A plus sign near the arrowhead indicates that the variable at the tail of the arrow and the variable at the head of the arrow change in the same direction. If the tail increases, the head increases; if the tail decreases, the head decreases.

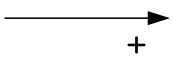

A minus sign near the arrowhead indicates that the variable at the tail of the arrow and the variable at the head of the arrow change in the opposite direction. If the tail increases, the head decreases; if the tail decreases, the head increases.

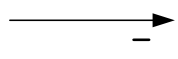

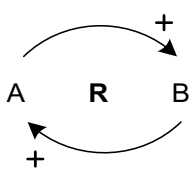

The letter $\mathbf{R}$ in the middle of a loop indicates that the loop is reinforcing a behavior in the same direction, causing either a systematic growth or decline. It is a behavior that is moving away from equilibrium point.

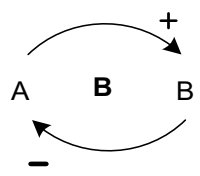

The letter $\mathbf{B}$ in the middle of a loop indicates that the loop is balancing and moves the system in the direction towards equilibrium or a fluctuation around equilibrium point.

Figure 1. Weathering processes were mapped using systems analysis and by drawing causal loop diagrams (CLD) for the process and the whole system of the weathering process. This is a standard procedure in model building (Sverdrup and Stiernquist 2002, Sverdrup et al., 2018). B is a balancing loop (sometimes referred to as a negative feedback) and $R$ is a reinforcing loop (sometimes referred to as a positive feedback) as explained in the figure.

\section{Methodology}

The methods used in this study have their basis in terrestrial ecosystems system analysis and ecosystems system dynamics as described by Sverdrup and Stiernquist (2002) and Sverdrup et al. (2018). The main tools employed are the standard methods of system analysis and integrated system dynamics modelling (Forrester 1961, 1969, 1971, Meadows et al., 1972, 1974, 1992, 2005, Roberts et al., 1982, Senge 1990, Bossel 1998, Haraldsson and Sverdrup 2005, Haraldsson et al., 2006, Sverdrup and Stiernquist 2002, Sverdrup et al., 2018). The overall system is analysed using stock-and-flow charts and causal loop diagrams (Sverdrup et al., 2002). The learning loop was used as the adaptive learning procedure in past studies (Senge 1990, Kim 1992, Senge et al., 2008, Sverdrup et al., 2018). The conceptual model must be clearly defined and constructed before any computational work can be undertaken. It is fundamental to understand that the causal understanding is the model. Systems analysis produces a causal loop diagram (CLD) linking causes, effects, and feedbacks among the processes in terms of causalities and flows (Albin 1997, Sverdrup et al., 2018, Kim 1992). These CLD need to be internally consistent. A summary of this approach is provided in Figure 1. A causal loop diagram is thus a map of the differential equations describing the evolution of the system. Mass- or energy flow charts and the causal loop diagram uniquely define the system. The ForSAFE model is not calibrated on large amounts of system output data (Sverdrup and Warfvinge 1992, Sverdrup et al., 2018). Instead, the system's causal linkages and the mass balances lead to equations that are parameterized using independent system properties, initial states and boundary conditions (Sverdrup et al., 2018).

\subsection{Earlier development work and background}

Critical to developing a database describing mineral dissolution rates is that it is coupled into a comprehensive model that can account for the large number of processes that affect rates in the field. From the beginning, weathering kinetics was developed and incorporated into the PROFILE model. The kinetics were parameterized using laboratory measurements and applied to field conditions on a plot scale and on a regional scale for Sweden (Sverdrup 1990, Sverdrup and Wafvinge 1988a,b, 1992, 1995, Warfvinge and Sverdrup 1992, 1993). The resulting kinetics sub-model was subsequently coupled into a biogeochemical ecosystem model, linking solute transport, soil chemistry, weathering, ion exchange, hydrology and biological 
interactions with microbiology and forest plants, called the SAFE model (Sverdrup et al, 1995). The steadystate model PROFILE and its dynamic variant SAFE, was further developed into other models as described in the Appendix.

\subsection{Weathering under field conditions}

The dissolution of primary minerals at ambient temperature and pressure is irreversible with the exceptions of a few simple chloride and sulphate salts and a few carbonates (Sverdrup 1990). Such irreversible reactions do not attain equilibrium in near to ambient temperate systems as the chemical species released to natural waters combine to form secondary solid phases far before the waters attain close to equilibrium conditions with respect to primary minerals. Nevertheless, the dissolution rates of the primary minerals have been observed to slow at far from equilibrium conditions in response to the increased concentration of dissolved metals including $\mathrm{Al}$ and $\mathrm{Si}$. A formulation based on transition state theory for the formation of activated surface complexes that decay irreversibly was developed by (Sverdrup 1985, Sverdrup and Warfvinge 1987, 1988a,b, 1992, Sverdrup 1990) to describe the effect of dissolved metals on primary mineral dissolution at far from equilibrium conditions. Taking account of this approach as well as their coupling to solute transport, ion exchange, plant nutrient uptake, organic matter decomposition and nitrogen transformations detailed modelling of chemical weathering rates have been made (Sverdrup and Warfvinge 1988a,b, Sverdrup 1990, Akselsson et al., 2006, 2005, 2004, Sverdrup et al., 1990, 1995, 2017). A comparison of calculated and observed weathering rates shown in Figure 2, demonstrates this approach can reproduce the observed rates within $\pm 5 \%$ across 4 orders of magnitude for the upper unsaturated parts of a soil (Sverdrup and Warfvinge 1992, Barkman et al., 1999, Jönsson et al., 1995, Belyazid 2005, Kurz et al., 1998a,b). Further comparisons of computed and calculated rates made with these models for field tests at Gårdsjön, Sweden and at various sites were published by Sverdrup et al. (1988a,b, 1993, 1995, 1996, 1998, 2010), Sverdrup (1990, 2009), Sverdrup and Alveteg (1998), Rietz (1995) and Warfvinge et al., (1996), and Holmqvist et al., (2003, 2002). In addition, several other authors tested this approach independently (In the United States; Kolka et al 1996, Phelan et al., 2014, in Scotland; Langan et al. 2006b, in Germany; Becker 2002, in New Zealand: Zabowski et al., 2007; tests on controlled experiments with granite slabs in the Swedish nuclear waste storage assessment research programme at Göteborg by Claesson-Nyström and Andersson 1996, in Swedish soil profiles; Lång 1998). Gunnar Jacks in KTH, Stockholm put these models to several blind test of the alteration of blank granite surfaces used for ancient rock carvings and controlled mini-catchments (Jacks, unpublished 1990). In each case a close correspondence was observed in calculated as compared to the field weathering rates. The current manuscript reports on our efforts to extend these accurate calculations to deeper in the soil column.

\section{Theory}

The kinetic weathering model presented in this manuscript originates from that of Sverdrup and Warfvinge (1987a,b, 1988a,b, 1992a, 1995) and Sverdrup (1990), but numerous features have been added since. Some of the updates have been described in later studies (Akselsson et al., 2005, 2005, 2006, 2007, Alveteg et al., 2000, Kurz et al., 1998a,b, Sverdrup et al., 1997, 2002, 2008). Further updates are described in this study. New weathering rate data published over the past 25 years have been regressed and new temperature dependencies and modifications of some rate coefficients has resulted (Sverdrup 2010, Sverdrup et al., 1998, Rizzetto et al., 2016, Holmqvist et al., 2002, 2003). The mineralogy and surface area inputs to the models are based on site measurements, and in general are not adjustable parameters. Some of parameters can be challenging to measure, such as some primary minerals with low soil content (apatite, epidote, pyroxene, amphiboles, garnets accurate to $0.1 \%$ ), or mineral surface area. However, getting accurate field estimates of the weathering rates is also challenging, as it requires making many assumptions, so may be of limited accuracy. Thus, we are comparing uncertain model estimates with equally or more uncertain field estimates at the best (Sverdrup et al., 1998). Nevertheless such comparisons are essential to validate model results. Of all the parameters needed for calculating mineral dissolution rates in natural systems using laboratory measured rates among the most challenging are mineral surface areas. Whereas in laboratory studies of the dissolution rates of individual minerals it is possible to measure directly the areas of cleaned mineral surfaces using gas adsorption techniques, field samples are more complex as they many contain the surfaces of several minerals and these surfaces can be covered by both organic substances or secondary minerals. Assuming that the surface area of each mineral in a soil is proportional to its mass or volume fraction may not be appropriate due to the differing typical shapes of distinct minerals. The protocols used to estimate the surface areas of natural minerals in soils within the PROFILE and the ForSAFE models have been reviewed in detail by Sverdrup (1990). 
https://doi.org/10.5194/bg-2019-464

Preprint. Discussion started: 27 March 2020

(c) Author(s) 2020. CC BY 4.0 License.

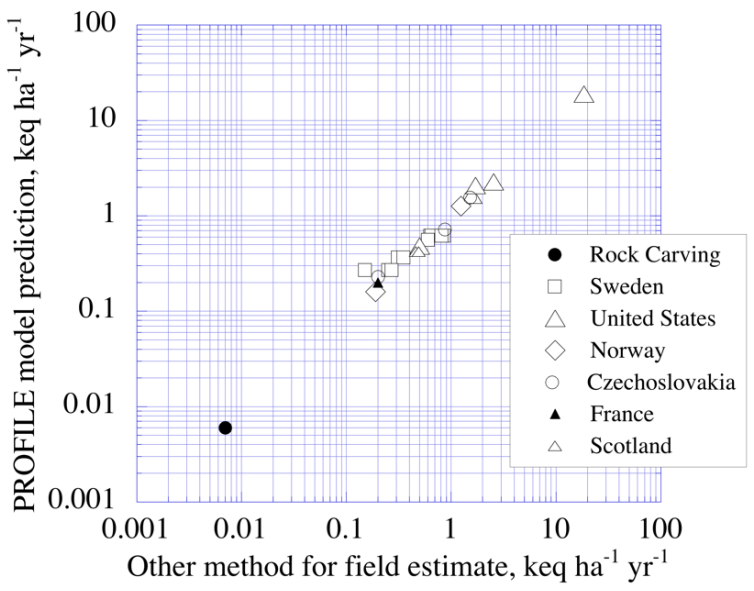

Figure 2. Comparison of weathering rates calculated using the original PROFILE model with corresponding rates obtained from field observations of the upper undersaturated parts of soils. Rates shown were reported or compiled by Sverdrup and Warfvinge (1988a,b, 1991, 1992, 1993, 1995, 1998), Sverdrup (1990), Sverdrup et al. (1990, 1998), Hettelingh et al. (1992), Barkmann et al. (1999), Holmqvist et al. (2003). The model test was performed on shallow soil profiles, no deeper than 0.6 meter.

\subsection{Defining chemical weathering}

Weathering neutralizes acids (neutralizing all or part of acid rain) and provides nutrients for vegetation (e.g. $\mathrm{Ca}^{2+}, \mathrm{Mg}^{2+}, \mathrm{K}^{+}, \mathrm{PO}_{4}$ ) (Sverdrup 1990, Sverdrup and Warfvinge 1995, Sverdrup et al., 2002). Thus weathering rates are defined as "the base cation release rates from the chemical weathering of minerals", "plant nutrient base cation release rates from the chemical weathering of minerals" or "the rate of acid neutralization by chemical weathering of soil minerals". Only secondarily are we interested in loss of minerals and soil profile development (Rietz 1995, Warfvinge et al., 1996, Sverdrup et al., 1996, 2002). Thus, the weathering rates in this study have been expressed as the sum of the release rates of base cations $\left(\mathrm{Ca}^{2+}, \mathrm{Mg}^{2+}, \mathrm{K}^{+}, \mathrm{Na}^{+}\right)$from the process. This is linked to the destruction of minerals, though results are generally expressed in these terms.
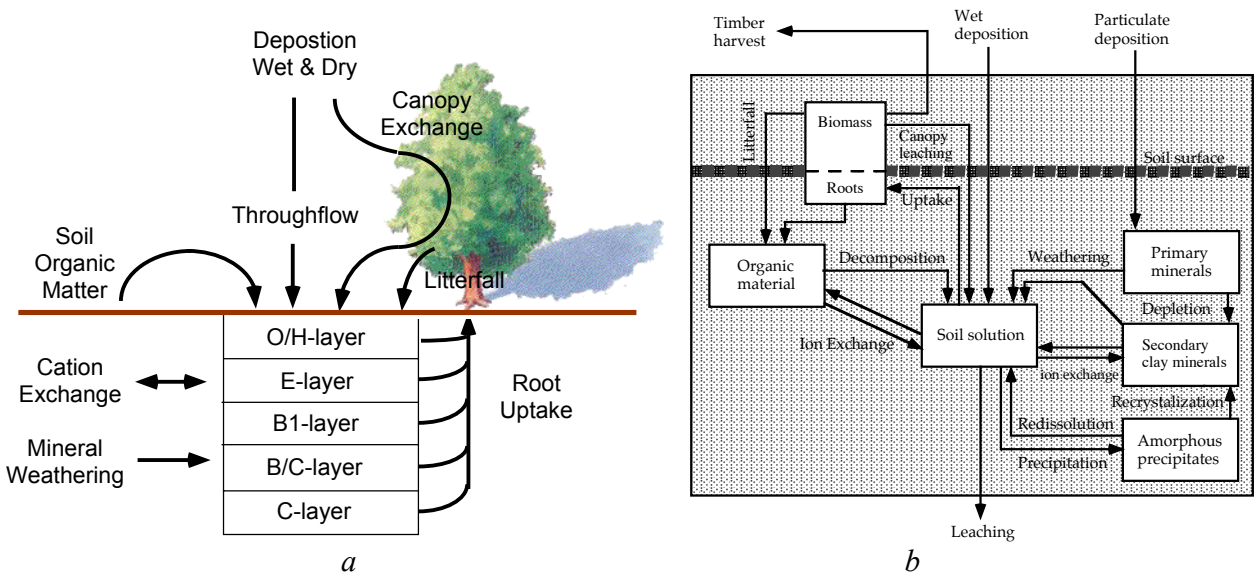

Figure 3. Overview of the PROFILE model. The original PROFILE model operates with a number of layers, and a vertical percolation of water. A set of processes take place in every layer. (b) A look inside PROFILE, showing how weathering is connected with other ecosystem processes (Sverdrup and Warfvinge 1995). 
Figure 4. Different soil processes communicate with the weathering processes via the soil solution. (Sverdrup et al., 2002).

\subsection{Mineral weathering rates}

The weathering rate of a mineral, $r$, defined here as its dissolution rate, is assumed to stem from the sum of 5 simultaneous chemical reactions, involving the mineral surface and either aqueous $\mathrm{H}^{+}, \mathrm{H}_{2} \mathrm{O}, \mathrm{OH}^{-}$, organic acid ligands, or $\mathrm{CO}_{2}$. Assuming that the reactions occur at distinct active mineral surface sites, they can be summed linearly in accord with (Sverdrup 1990, Sverdrup and Warfvinge 1995):

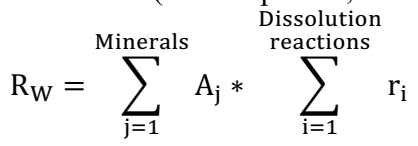

where $R_{W}$ stands for the soil weathering rate in a single soil layer. $A_{j}$ refers to the soil mineral surface available for dissolution for each mineral $\mathrm{j}$ considered, $\mathrm{r}_{\mathrm{i}}$ designates the rate of the individual chemical reactions $\mathrm{i}$. If some reactions occupy the same active mineral surface sites, the expression given above would change to a quadratic sum. Note that the results of the two equations are quite similar, so that the importance of knowing if several reactions operate of the same surface site is relatively small. For the whole soil profile the rates are summed over the different soil layers with depth and we get:

$$
\mathrm{R}_{\text {Soil }}=\sum_{\mathrm{s}=1}^{\text {Layers }} \mathrm{R}_{\mathrm{W}, \mathrm{s}}
$$

where $\mathrm{R}_{\text {Soil }}$ denotes the weathering rate in the whole soil profile, and s represents the layer number. Evidence that the $\mathrm{H}^{+}, \mathrm{H}_{2} \mathrm{O}$ and $\mathrm{OH}^{-}$reactions take place at distinct surface sites has been reviewed by Sverdrup (1990) and again by Holmqvist et al., (2003). The $\mathrm{H}_{2} \mathrm{O}$, the organic reaction and the $\mathrm{CO}_{2}$ reactions may occur at the same sites, but considering the available data, we have assumed that they occur at distinct sites and thus favour a linear sum of rates. More on these assumptions have been reported by Sverdrup (1990), Sverdrup and Warfvinge (1995), and Holmqvist et al. (2002, 2003).

\subsection{Field weathering rates}

To estimate field weathering rates using laboratory determined kinetic coefficients, an ecosystem model is required to scale the process to field conditions. This ecosystem model includes effects of climate, soil morphology, plants, trees, microbiology in the soil and fungi (Lin et al., 2017, Smits and Wallander 2016, Smits et al., 2014). An ecosystem model is incorporated within PROFILE and ForSAFE (Sverdrup and Warfvinge 1988a,b, 1991, 1992, 1993, 1995, 1998, Sverdrup 1990, Sverdrup et al., 1998, Hettelingh et al., 1992, Barkmann et al., 1999, Holmqvist et al., 2003, Barkman et al., 1999). Figure 3 shows how the steadystate PROFILE model was configured (Sverdrup and Warfvinge 1988a,b, 1992, 1993, Sverdrup and Alveteg 1998). In the dynamic integrated terrestrial ecosystem assessment model ForSAFE-VEG, the system evolution takes account of interactions with a living biosphere, organic matter turnover and ion exchange (c.f. Figure 4). Further details of these models can be found in the appendix and the literature (Sverdrup et al., 1987, 1995, 
1996a,b, 1998, 2007, 2014, 2016, 2017, 2019, Wallman et al., 2002, 2003, Zancchi et al., 2014, 2016a,b, Belyazid et al., 2017, 2018).

To estimate field weathering rates, each reaction $\mathrm{i}$ for every mineral $\mathrm{j}$ is corrected for the field site temperature and for the partial wetting of the soil (Sverdrup 1990, Sverdrup and Warfvinge 1995, Sverdrup and Alveteg 1998) in accord with:

$$
\mathrm{R}_{\mathrm{W}}=\mathrm{h}(\theta) * \sum_{\mathrm{j}=1}^{\text {Minerals }} \mathrm{A}_{\mathrm{j}} * \sum_{\mathrm{i}=1}^{\substack{\text { Dissolution } \\ \text { reactions }}}\left(\mathrm{r}_{\mathrm{i}} * \mathrm{~g}_{\mathrm{i}, \mathrm{j}}(\mathrm{T})\right)
$$

where $\theta$ stands for the fraction of the soil mineral surfaces wetted, $A_{j}$ designates the surface area of the mineral $\mathrm{j}, \mathrm{h}(\theta)$ refers to a wetting function for the mineral material and $\mathrm{T}$ signifies the soil temperature in centigrade. $\mathrm{g}_{\mathrm{ij}}(\mathrm{T})$ corresponds to the temperature adjustment function for reaction $\mathrm{i}$ of mineral $\mathrm{j} . \mathrm{r}_{\mathrm{i}}$ denotes the reaction rate of dissolution reaction i. This adjustment is based on the Arrhenius equation and takes account of the difference in rates between the temperature of the field site and that of the parameter database, which was set at $8^{\circ} \mathrm{C}$ (Sverdrup 1990). Figure 6 shows the reaction causal loop diagram for silicate minerals in the soil (Sverdrup 1990, Sverdrup and Warfvinge 1995). This diagram shows how the mineral weathering process communicates with other biogeochemical processes in a terrestrial ecosystem. The causal loop diagram is a graphical display of the differential balances in the system. Together with the flow charts, they define the system. The process has several intermediate equilibrium steps, but pass an irreversible dissolution threshold (Figure 7). The single irreversible step makes the whole process irreversible. The reaction products exert a negative effect on the amount of activated complex that can decay, thus they slow the dissolution reaction. But once the activated complex has formed, it has a constant decay rate, set by quantum mechanics (Sverdrup 1990, Sverdrup and Warfvinge 1995). The full derivation of the rate equations, starting from the elementary chemical reactions and the decay of the surface complexes according to transition state theory has been reviewed by Sverdrup (1990) and Sverdrup and Warfvinge (1995).

\subsection{Mineral reaction kinetics}

As stated above, five reactions are assumed to contribute to the total chemical weathering rate of a silicate mineral in soils (Sverdrup 1990, 2009, Sverdrup and Warfvinge 1995):

1. The reaction between the mineral surface and the aqueous hydrogen ion

2. The reaction between the mineral surface and the water molecule

3. The reaction between the mineral surface and aqueous carbon dioxide

4. The reaction between the mineral surface and aqueous organic acid ligands

5. The reaction between the mineral surface and the aqueous hydroxy ion

Reactions 1-4 in the list above were included in earlier versions of the PROFILE and ForSAFE mineral dissolution rate equations (Sverdrup 1990, Sverdrup and Warfvinge 1995). This original model has been enlarged to include reaction 5 .

The reaction of the mineral surface with the aqueous $\mathrm{H}^{+}$ion, reaction 1 , is considered part of the reaction with the $\mathrm{H}^{+}$reaction regardless of the source of $\mathrm{H}^{+}$(Figures 5 and 7). Both $\mathrm{CO}_{2}$ and organic acids can change the fluid $\mathrm{pH}$, and this is accounted for in the $\mathrm{H}^{+}$reaction. Figure 5 shows the reaction pathway through the $\mathrm{H}^{+}$reaction, adapted after Sverdrup (1990). Some of the reaction products form secondary minerals. Amorphous phases may also precipitate from solution. These can slowly recrystallize to secondary minerals. This has been generalized in Figure 6.

Reaction number 4 between organic acid ligands and the mineral surface contains at least two distinct contributions: one from fast and one from slower reacting organic acid ligands (Sverdrup 1990). We have simplified this to one generic rate equation that could be parameterized for some minerals (feldspar, olivine, pyroxenes, hornblende, apatite; Sverdrup et al., 1990, later literature has extended the list somewhat). The importance of organic acids for weathering has been frequently over estimated in the literature, and several claims of strong effects of organic acids have been made (For a review see Smits and Wallander 2016, Smits et al., 2014, Sverdrup 1990, 2009 but also Keegan and Laskow-Lehey 2014 on why these claims have been so persistent). The highest concentration of organic acids occur in the upper soil layers, where the mineral content is relatively low. As the mineral contents increase with depth, the concentrations of organic acids are lower and have only a marginal effect on the overall weathering rate (Sverdrup 2009). 
Organic acids in soils are mostly sourced from soil organic matter decomposition. Trees, soil fungi and mycorrhiza do not have the ability to increase the weathering rate significantly (See Sverdrup 1990, 2009, Sverdrup and Warfvinge 1992, Warfvinge and Sverdrup 1993 for details, kinetic expressions and data underpinning this, see Smits and Wallander 2016 and Smits et al., 2014 on the subject concerning apatite). Trees and vegetation can indirectly affect weathering rates when they take up $\mathrm{Ca}, \mathrm{Mg}, \mathrm{K}$ as nutrients, and thereby removing weathering rate products that can slow mineral dissolution. Decomposition of plant debris and soil organic matter produce organic acids that may react with the minerals. This effect is passive, and does not occur not by design of the plants (See Smits and Wallander 2016 and Smits et al., 2014 for measurements, Keegan and Laskow-Lehey 2014 for some social aspects and Sverdrup 2009 for a further analysis from a systemic perspective).

Figure 5. The reaction pathway through the $H^{+}$reaction passes over several reversible steps that change the surface sites and create an unstable surface complex; the Transition State Surface Complex that will decay irreversibly. Note that the process is irreversible, and thus cannot go backwards. The mineral may dissolve completely, be altered to a secondary mineral or form precipitates that slowly recrystalize to secondary solid phases.

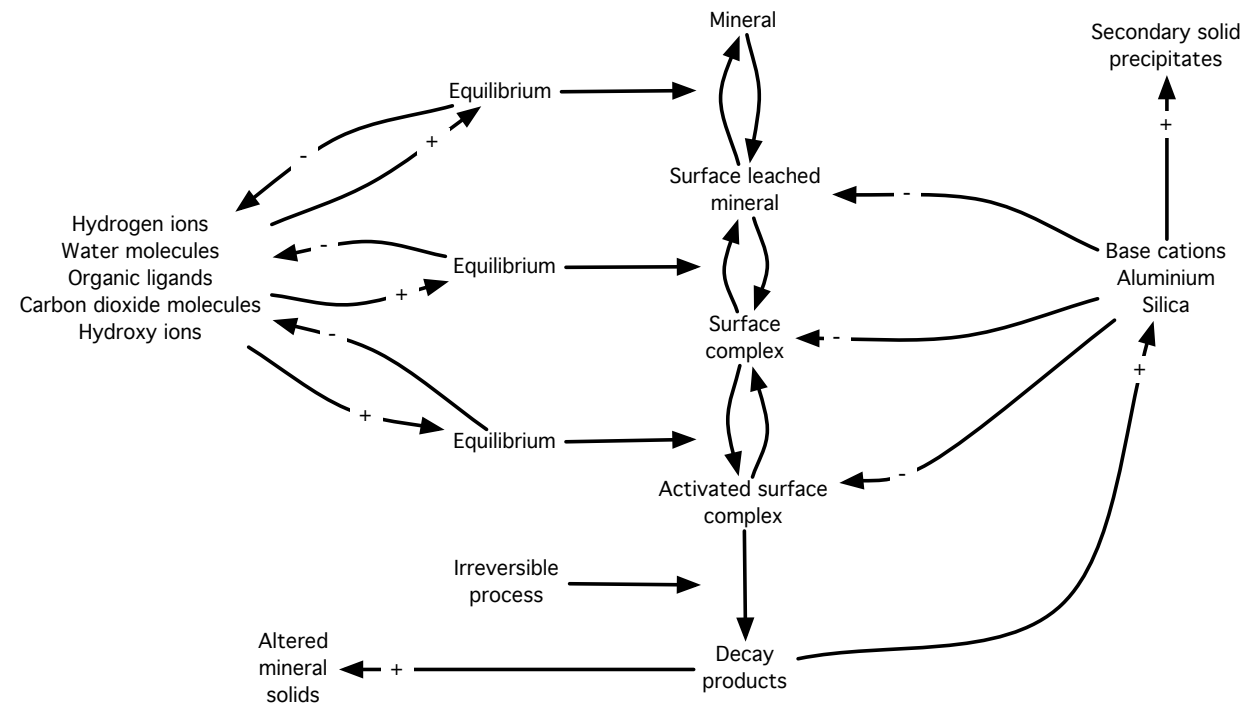

Figure 6. Reaction pathway for silicate minerals in soils according to Transition State Theory as implemented by the authors (See Sverdrup 1990, Sverdrup and Warfvinge 1995 for a full explanation). 


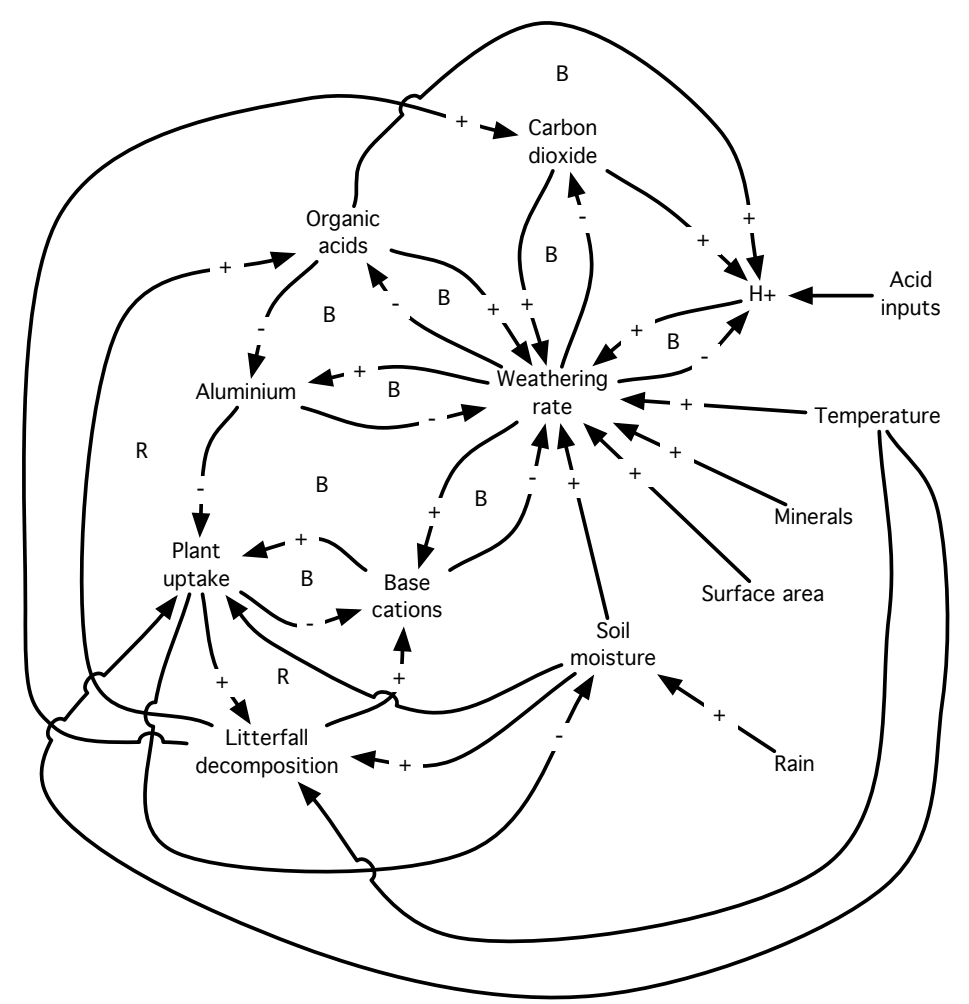

Figure 7. The partial causal loop diagram for the weathering of a soil. See Sverdrup et al. (2018) for a full explanation of causal loop diagrams and their use in modelling.

Fluorides form soluble complexes in water with aluminium and silicates. The reaction of the mineral surface with fluoride anions forms a strong reactions, but this occurs very rarely as the fluoride concentrations are very low. The fluoride reaction has been ignored in this approach for most soils in natural terrestrial ecosystems, as this would cause an unnecessary complication of the aluminium and silicate chemistry. The dissolution rate per surface area of a mineral considering the first of the four above reactions is thus consistent with (Sverdrup and Warfvinge 1988, 1992):

$$
\mathrm{r}_{\text {Total }}=\mathrm{r}_{\mathrm{H}^{+}}+\mathrm{r}_{\mathrm{H}_{2} \mathrm{O}}+\mathrm{r}_{\mathrm{CO}_{2}}+\mathrm{r}_{\mathrm{R}}
$$

The mineral dissolution kinetic equation for the 4 individual reactions applied in the original PROFILE model was the simplified version of the full kinetic expression based on the Transition State Theory applied to silicate chemical weathering (see Sverdrup 1990, Sverdrup and Warfvinge 1995):

$\mathrm{r}=\mathrm{k}_{\mathrm{H}} * \frac{\left[\mathrm{H}^{+}\right]^{\mathrm{n}_{\mathrm{H}}}}{\mathrm{f}_{\mathrm{H}}}+\frac{\mathrm{k}_{\mathrm{H}_{2} \mathrm{O}}}{\mathrm{f}_{\mathrm{H}_{2} \mathrm{O}}}+\mathrm{k}_{\mathrm{CO}_{2}} * \mathrm{P}_{\mathrm{CO}_{2}}^{\mathrm{n}_{\mathrm{CO}_{2}}} * \frac{1}{\mathrm{f}_{\mathrm{CO}_{2}}}+\mathrm{k}_{\mathrm{R}} * \frac{[\mathrm{R}]^{n_{R}}}{1+\mathrm{K}_{\mathrm{Org}} *[\mathrm{R}]^{n_{R}}} * \frac{1}{\mathrm{f}_{\mathrm{R}}}$

where the different $\mathrm{n}$ designate reaction orders. The different $\mathrm{k}_{\mathrm{H}}, \mathrm{k}_{\mathrm{H} 2 \mathrm{O}}, \mathrm{k}_{\mathrm{CO} 2}, \mathrm{k}_{\mathrm{R}}$ stand for rate coefficients. Constitutents within brackets [c] are concentrations, and $\mathrm{R}$ refers to organic ligands. The different $\mathrm{f}_{\mathrm{H}+}, \mathrm{f}_{\mathrm{H} 2 \mathrm{O}}$, $\mathrm{f}_{\mathrm{CO} 2}, \mathrm{f}_{\mathrm{R}}, \mathrm{f}_{\mathrm{OH}}$ signify retarding or 'brake' functions defined by (Sverdrup 1990, Sverdrup and Warfvinge 1992, Warfvinge and Sverdrup 1993, Sverdrup and Warfvinge 1995):

$$
\mathrm{f}_{\mathrm{H}^{+}}=\left(1+\frac{[\mathrm{BC}]}{\mathrm{C}_{\mathrm{BC}, \mathrm{H}}}\right)^{\mathrm{x}_{\mathrm{H}}} *\left(1+\frac{\left[\mathrm{Al}^{3+}\right]}{\mathrm{C}_{\mathrm{Al}, \mathrm{H}}}\right)^{\mathrm{y}_{\mathrm{H}}}
$$




$$
\begin{aligned}
& \mathrm{f}_{\mathrm{H}_{2} \mathrm{O}}=\left(1+\frac{[\mathrm{BC}]}{\mathrm{C}_{\mathrm{BC}, \mathrm{H}_{2} \mathrm{O}}}\right)^{\mathrm{x}_{\mathrm{H}_{2} \mathrm{O}}} *\left(1+\frac{\left[\mathrm{Al}^{3+}\right]}{\mathrm{C}_{\mathrm{Cl}_{1} \mathrm{H}_{2} \mathrm{O}}}\right)^{\mathrm{y}_{\mathrm{H}_{2} \mathrm{O}}} \\
& \mathrm{f}_{\mathrm{CO}_{2}}=\left(1+\frac{[\mathrm{BC}]}{\mathrm{C}_{\mathrm{BC}, \mathrm{CO}_{2}}}\right)^{\mathrm{x}_{\mathrm{CO}_{2}}} *\left(1+\frac{\left[\mathrm{Al}^{3+}\right]}{\mathrm{C}_{\mathrm{Al}, \mathrm{CO}_{2}}}\right)^{\mathrm{yCO}_{2}} \\
& \mathrm{f}_{\mathrm{R}}=\left(1+\frac{[\mathrm{BC}]}{\mathrm{C}_{\mathrm{BC}, \mathrm{R}}}\right)^{\mathrm{x}_{\mathrm{R}}} *\left(1+\frac{\left[\mathrm{Al}^{3+}\right]}{\mathrm{C}_{\mathrm{Al}, \mathrm{R}}}\right)^{\mathrm{y}_{\mathrm{R}}} \\
& \mathrm{f}_{\mathrm{OH}^{-}}=\left(1+\frac{[\mathrm{BC}]}{\mathrm{C}_{\mathrm{BC}, \mathrm{OH}}}\right)^{\mathrm{x}_{\mathrm{OH}}} *\left(1+\frac{\left[\mathrm{Al}^{3+}\right]}{\mathrm{C}_{\mathrm{Al}, \mathrm{OH}}}\right)^{\mathrm{y}_{\mathrm{OH}}}
\end{aligned}
$$

Note that the retardation or 'braking' functions represent molecular mechanisms that slow the reaction by forming fewer active surface complexes (Sverdrup 1990, Sverdrup and Warfvinge 1995). $\mathrm{Al}^{3+}$ is the concentration of positive aluminium species in the aqueous solution, and not necessarily equal to the total aluminium concentration (Sverdrup 1990 - see also section 4.8); this concentration can be calculated using aqueous speciation estimates as described below. The subscript $\mathrm{BC}, \mathrm{OH}$ represents a term related to base cations $(\mathrm{BC})$ in the $\mathrm{OH}^{-}$reaction, Note this slowing of the rates with increasing fluid concentration is not due to the approach to a mineral-water equilibrium state. The dissolution of many primary silicate minerals is not reversible under normal soil conditions as the fluids do not attain close to equilibrium conditions. Instead, there will be a steady-state between the reaction at the surface and the removal of ions by solute transport and precipitation into secondary phases. This may look like an equilibrium condition, but does not behave like one. A few minerals are exceptions such as calcite, a few other carbonates, hydroxides and quartz. Even with these the attainment of equilibrium is kinetically limited. For calcite in soils we have observed this to take several days or weeks (Warfinge et al., 1987). All other minerals (feldspars, pyroxenes, amphiboles, etc.) do not precipitate from solution, some amorphous aluminosilicate clay precursors only precipitate very slowly.

\subsection{The updated kinetics equation}

The original 4 mineral dissolution reactions have been enlarged to include $\mathrm{OH}^{-}$-reaction in the present study. The complete equation is consistent with

$$
\mathrm{r}_{\text {Total }}=\mathrm{r}_{\mathrm{H}^{+}}+\mathrm{r}_{\mathrm{H}_{2} \mathrm{O}}+\mathrm{r}_{\mathrm{CO}_{2}}+\mathrm{r}_{\mathrm{R}+}+\mathrm{r}_{\mathrm{OH}^{-}}
$$

The full kinetic equation for all 5 reactions is (Sverdrup 1990, Sverdrup and Warfvinge 1995):

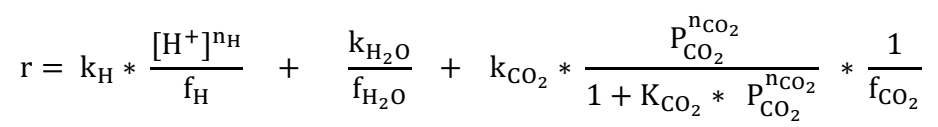

$$
+\mathrm{k}_{\mathrm{R}} * \frac{[\mathrm{R}]^{n_{R}}}{1+\mathrm{K}_{\mathrm{Org}} *[\mathrm{R}]^{n_{R}}} * \frac{1}{\mathrm{f}_{\mathrm{R}}}+\mathrm{k}_{\mathrm{OH}} * \frac{\left[\mathrm{OH}^{-}\right]^{\mathrm{n}_{\mathrm{OH}}}}{\mathrm{f}_{\mathrm{OH}}}
$$

For most minerals, the strongest effect of the brake functions is that of aluminium at $\mathrm{pH}<7$, followed by silica and base cations. At $\mathrm{pH}>8$, the strongest effect is from silica and base cations, and less pronounced for aluminium (Sverdrup 1990). Before applying Equation (12) a number of new adaptions have been carried out as described below.

\subsection{Retardation of mineral dissolution rates by organic ligands}

The original formula for the slowing of mineral dissolution rates with increasing organic ligand concentration was (Sverdrup 1990, Sverdrup and Warfvinge 1995):

$$
\mathrm{r}_{\text {org }}=\mathrm{k}_{\mathrm{R}} * \frac{[\mathrm{R}]^{n_{R}}}{1+[\mathrm{R}]^{n_{R}}} * \frac{1}{\mathrm{f}_{\mathrm{R}}}
$$

this has been reformulated to: 


$$
\mathrm{r}_{\text {org }}=\mathrm{k}_{\mathrm{R}} *\left(\frac{[\mathrm{R}]}{1+\left[\mathrm{R}+[\mathrm{R}]_{\text {limit }}\right]}\right)^{\mathrm{n}_{\mathrm{R}}} * \frac{1}{\mathrm{f}_{\mathrm{R}}}
$$

404

The difference in these equations is that the latter contains one additional parameter $[R]_{\text {Limit }}$ in $f_{R}$ that has the effect to set a lower concentration, below which the organic acids have no effect. This equation has been parameterized and used in the final expression provided below. This limit was incorporated into the organic acid ligand retardation function $f_{R}$ (Smits and Wallander 2016, Smits et al., 2014, Sverdrup 1990, 2009).

\subsection{Retardation of mineral dissolution rates by aqueous $\mathrm{CO}_{2}$}

The main effect of the presence of $\mathrm{CO}_{2}$ on mineral dissolution rates is to change the $\mathrm{pH}$ of the solution. This effect is accounted for by the chemical solution equilibria, and dealt with in the $\mathrm{H}^{+}$reaction. The dedicated $\mathrm{CO}_{2}$ term takes into account the effect of a reaction between the $\mathrm{CO}_{2}$ and the mineral surface. The effect of the presence of aqueous organic species decreases at higher concentrations of organic acids as the surface sites have become saturated with organic acid ligands. We hypothesize that $\mathrm{CO}_{2}$ exhibits the same behaviour. Some data show that $\mathrm{CO}_{2}$ also reacts with mineral surface sites as some type of carbonate ligand (a bicarbonate coordinated towards a cation in the lattice) adsorbed to the surface, setting up a transitional surface complex may decay. The mechanism by which $\mathrm{CO}_{2}$ effects silicate dissolution rates appears to follow the sequence (Sverdrup 1990, Sverdrup and Warfvinge 1995, Brady and Carrol 1994, Golubev et al., 2005, Navarre-Sitchler and Thyne 2007, Berg and Banwart 2000):

1. The $\mathrm{CO}_{2}$ molecule attaches to the mineral surface

2. The $\mathrm{CO}_{2}$ molecule forms a bicarbonate-water-metal complex with the mineral surface on singly coordinated metal cations. Indications are that it may be the $\mathrm{CO}_{3}{ }^{2-}$ ligand that is forming a surface complex.

3. A cation is lifted into the complex $(\mathrm{K}, \mathrm{Na}, \mathrm{Mg}, \mathrm{Ca}, \mathrm{Fe}$, etc..)

4. A small fraction of the surface complexes detach from the surface and the mineral dissolves.

Thus there should potentially be an upper concentration limit where additional aqueous $\mathrm{CO}_{2}$ will have no further effect on mineral dissolution rates. This seems to occur between 10 and 50 atmospheres of $\mathrm{CO}_{2}$ partial pressure for mica and chlorites (Drever et al., 1996, Mast and Drever 1987, Hausrath et al., 2009). Observations on some other minerals indicate of a similar behaviour, but this limit remains elusive due to lack of data. In addition the dissolution rates of some minerals exhibit no detectable effect of the presence of aqueous $\mathrm{CO}_{2}$, and some are only slightly inhibited by this species. Lagache $(1965,1976)$, Busenberg and Clemency (1976), Berg and Banwart (2000) and Golubev et al., (2005) reported experiments performed at different $\mathrm{CO}_{2}$ partial pressures between 0 and $26.3 \mathrm{CO}_{2}$ atmospheres and temperatures between $0{ }^{\circ} \mathrm{C}$ and $200{ }^{\circ} \mathrm{C}$. The original equation used by Sverdrup (1990) and Sverdrup and Warfvinge (1995) to describe these data was

$$
\mathrm{r}_{\mathrm{CO}_{2}}=\mathrm{k}_{\mathrm{CO}_{2}} * \frac{\mathrm{P}_{\mathrm{CO}_{2}}^{\mathrm{n}_{\mathrm{CO}_{2}}}}{1+\mathrm{K}_{\mathrm{CO}_{2}} * \mathrm{P}_{\mathrm{CO}_{2}}^{\mathrm{n}_{\mathrm{CO}_{2}}}} * \frac{1}{\mathrm{f}_{\mathrm{CO}_{2}}}
$$

In this study we use a variation of this equation of the form:

$$
\mathrm{r}_{\mathrm{CO}_{2}}=\mathrm{k}_{\mathrm{CO}_{2}} *\left(\frac{\mathrm{P}_{\mathrm{CO}_{2}}}{1+\mathrm{K}_{\mathrm{CO}_{2}} *\left(\mathrm{P}_{\mathrm{CO}_{2}}+\mathrm{P}_{\mathrm{CO}_{2} \text { Limit }}\right)}\right)^{\mathrm{n}_{\mathrm{CO}_{2}}} * \frac{1}{\mathrm{f}_{\mathrm{CO}_{2}}}
$$

Evidence suggests that the value of $\mathrm{P}_{\mathrm{Limit} \mathrm{CO} 2}$ is in the range of 5 to 10 atmospheres and $\mathrm{K}_{\mathrm{CO} 2}=0.05$ and $\mathrm{n}_{\mathrm{CO} 2}$ $=0.6$ for albite (Sverdrup 1990). Navarre-Sitchler and Thyne (2007) suggest $\mathrm{n}_{\mathrm{CO} 2}=0.45$, which is for practical purposes the same. Berg and Banwart (2000) suggested $\mathrm{n}_{\mathrm{CO} 2}=0.25$ at low pressures of $\mathrm{CO}_{2}$. As mentioned above, a similar behaviour was observed for mica, biotite and chlorites. Indications are that something similar takes place on the surface of montmorillonite, diaspore, gibbsite, goethite and lepicrocite. There almost no experimental data available allowing the retrievial of the parameters in Equation (16) for other minerals. The effect of increasing aqueous $\mathrm{CO}_{2}$ has been overlooked in most experimental studies. 


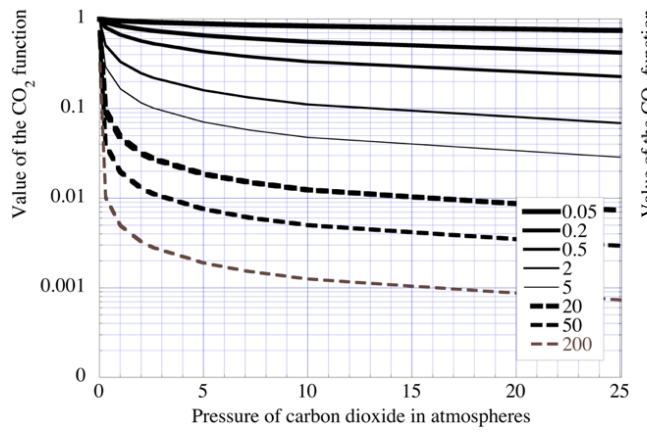

$a$

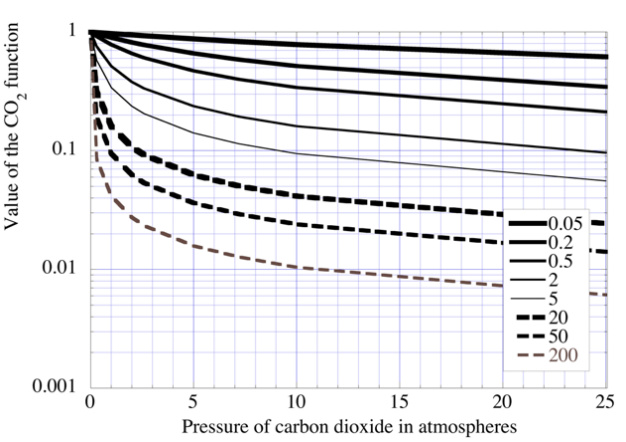

b

Figure 8. The calculated effect of aqueous carbon dioxide on mineral dissolution reactions using Equation 15 in (a) and Equation 16 in (b). See Table 2 for values for different minerals.

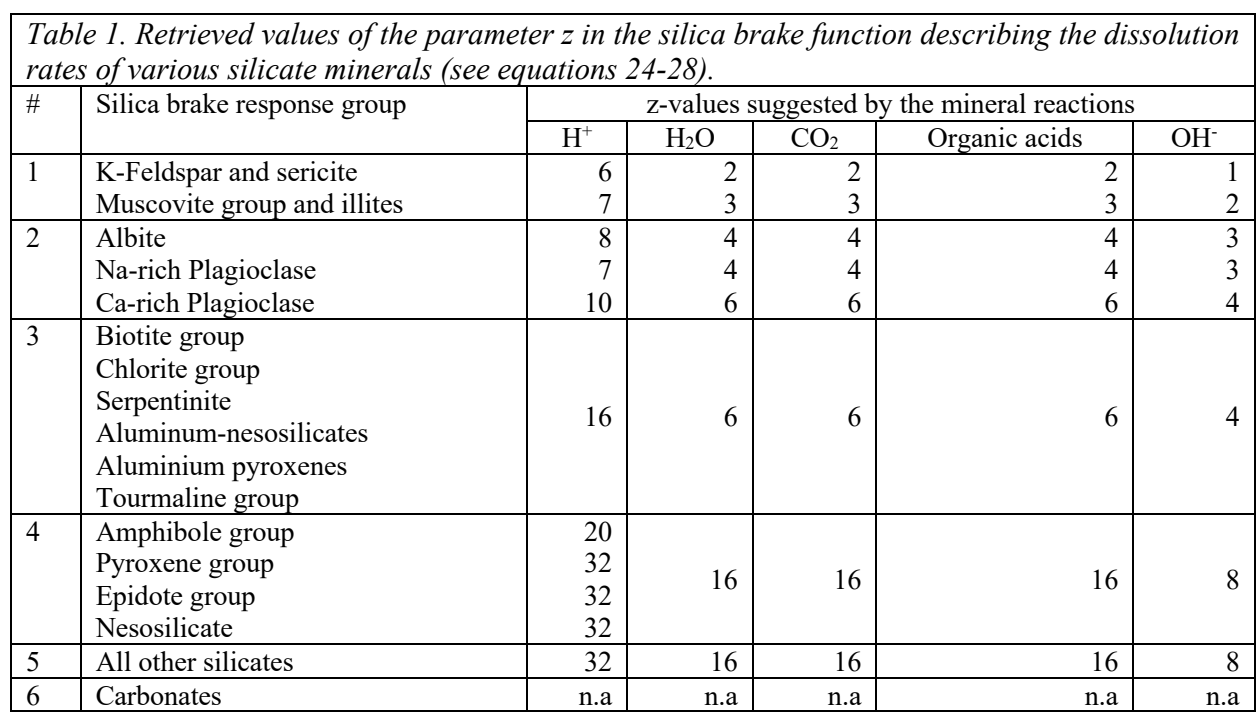

Values calculated of the effect of aqueous $\mathrm{CO}_{2}$ on silicate dissolution rates are illustrated in Figure 8. These calculations suggests that there is a significant saturation of the surface with $\mathrm{CO}_{2}$ at approximately 5 to 10 atmospheres partial pressure of $\mathrm{CO}_{2}$. See Table 1 for the z-values suggested for different minerals. Note that the values of this parameter are based on minimal supporting experimental data - the available experimental data are few and somewhat incomplete (See Golubev et al., 2005 for a limited but useful assessment). Overall, the effect of $\mathrm{CO}_{2}$ at normal soil conditions is limited. Nevertheless, these results provide a range for model parameter adjustment. The effect of dissolved $\mathrm{CO}_{2}$ on rates may become significant for deep aquifers, subsurface $\mathrm{CO}_{2}$ storage and in industrial high-pressure situations (Sverdrup 1990).

\subsection{The silica retarding or 'brake' function}

An illustrative plot of the effect of aqueous silica on silicate mineral dissolution rates is provided in Figure 9. The equation used to describe the retardation effect of dissolved $\mathrm{Si}$ on mineral dissolution rates was:

$$
\frac{1}{\mathrm{f}_{\mathrm{Si}}}=\frac{1}{1+\mathrm{K}_{\mathrm{Si}, \mathrm{i}} *\left(\frac{[\mathrm{Si}]}{\mathrm{C}_{\mathrm{Si}}}\right)^{\mathrm{z}_{\mathrm{Si}}}}
$$

The value for the silica brake coefficient $\mathrm{K}_{\mathrm{S}, \mathrm{i}}=100$ was chosen, and causes a gradual reduction in the dissolution rate of minerals down to a minimum of approximately $0.9 \%$ of the rate unaffected by silica at very high silica concentrations (see Table 1). Figure 9 shows values of the silica brake function calculated using 
Equation 17, using the surface constant value, $\mathrm{K}_{\mathrm{Si}}=100$, and the saturation concentration $\mathrm{C}_{\mathrm{Si}}=900 \mathrm{mmol}$ per $\mathrm{m}^{3}$ in Equation 17 together with the coefficients in Table 3. Exponents from $\mathrm{z}_{\mathrm{Si}}=0.5$ to 32 in Equation (17) of the silica rate brake are shown in Figure 9.

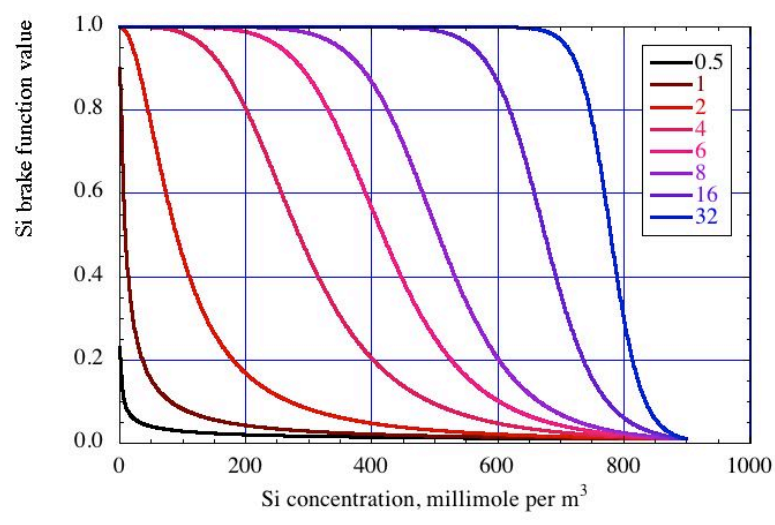

Figure 9. Calculated effect of dissolved Si on silicate dissolution rates generated using Equation (17) together with $K_{S i}=100$, and the saturation concentration, $C_{S i}=900 \mathrm{mmol} \mathrm{per} \mathrm{m}^{3}$ and the coefficients in listed in Table 1 .

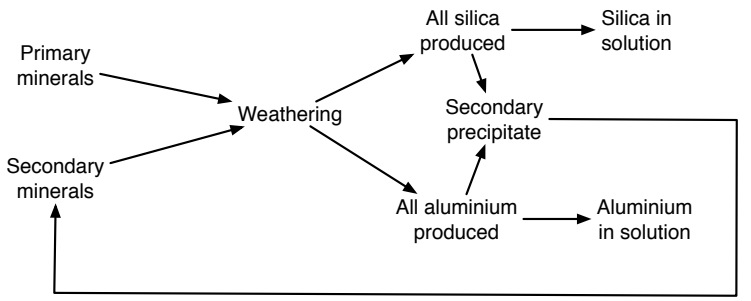

$a$

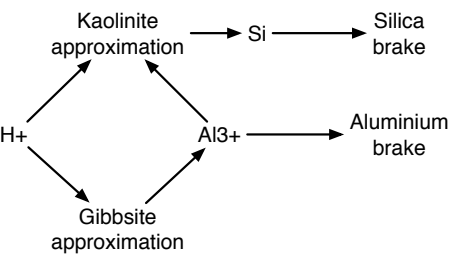

$b$

Figure 10. a) Plot illustrating the fate of silica during the mineral dissolution process. b) Diagram showing how the aluminium and silica concentrations are estimated in the model. The $H^{+}$concentration is used with the equation called the "Gibbsite" equation (Eq. 19) to estimate the Al ${ }^{3+}$ concentration in the soil solution. These $\mathrm{H}^{+}$and $\mathrm{Al}^{3+}$ concentrations are used in Equation 21 to estimate the silica concentration that is used to quantify the silica 'brake' on the mineral weathering reactions.

Figure 10a shows a plot illustrating the fate of silica in the dissolution process. Only a small part of the aqueous aluminium and aqueous silica produced by the dissolution of minerals remain in solution. Most precipitates out as secondary phases. Figure 10b shows how the aluminium and silica concentrations are estimated in the model. To estimate $\left[\mathrm{Al}^{3+}\right]$ and $\left[\mathrm{SiO}_{2}\right]$ in the above equations we assume the systems are close to equilibrium with a gibbsite-like and a kaolinite-like phase. Thus we assume that aluminium precipitates out from the solution, controlled by something that appears to be gibbsite-like; it is likely something amorphous of unknown composition, see Alveteg et al. (1995). The "Gibbsite" reaction is:

$$
\mathrm{Al}^{3+}+3 \mathrm{OH}^{-}=\mathrm{Al}(\mathrm{OH})_{3}
$$

Leading to the "Gibbsite" expression:

$$
\left[\mathrm{Al}^{3+}\right]=\mathrm{K}_{\mathrm{G}} *\left[\mathrm{H}^{+}\right]^{\mathrm{Y}}
$$

where the exponent $\mathrm{Y}$ has a value of 2.4 to $3 . \mathrm{K}_{\mathrm{G}}$ is the Gibbsite coefficient and defined in the critical loads mapping manual (Sverdrup et al., 1990). An expression analogous to the Gibbsite approximation is used to calculate the $\mathrm{SiO}_{2}$ concentration (Equation 22b, below). We assume that the $\mathrm{Si}$ will be present as $\mathrm{H}_{4} \mathrm{Si}(\mathrm{OH})_{4}$ in the fluid phase, not upsetting any charge balance constraints. We assume that silica precipitates out, controlled by what that appears to be kaolinite. As such, there is a similar expression can be used for approximating the silica concentration: 
where the retarding or 'brake' functions are given by:

$$
\left[\mathrm{SiO}_{2}\right]=\mathrm{K}_{\text {Kaolinite }} * \frac{\left[\mathrm{H}^{+}\right]^{3}}{\left[\mathrm{Al}^{3+}\right]}
$$

where $\mathrm{K}_{\text {Kaolinite }}$ is the equilibrium coefficient being used. Note that the "equilibrium" equations assumed above, are not true equilibrium, and that kaolinite and gibbsite minerals dissolve very slowly under normal conditions. Both the "gibbsite" and "kaolinite" mentioned above are crude simplifications, possibly representing an amorphous precipitate combined with precipitation kinetics and ion exchange (see Alveteg et al., 1995, Rietz 1995, Warfvinge et al., 1996 for more information).

\subsection{The full kinetic expression}

The equations and approximations summarized above leads to the full revised mineral dissolution rate equations given by

$$
\begin{aligned}
\mathrm{r}=\mathrm{k}_{\mathrm{H}} * \frac{\left[\mathrm{H}^{+}\right]^{\mathrm{n}_{\mathrm{H}}}}{\mathrm{f}_{\mathrm{H}}}+\frac{\mathrm{k}_{\mathrm{H}_{2} \mathrm{O}}}{\mathrm{f}_{\mathrm{H}_{2} \mathrm{O}}}+\mathrm{k}_{\mathrm{CO}_{2}} * \mathrm{P}_{\mathrm{CO}_{2}}^{\mathrm{n}_{\mathrm{CO}_{2}}} * \frac{1}{\mathrm{f}_{\mathrm{CO}_{2}}} \\
+\mathrm{k}_{\mathrm{R}} *[\mathrm{R}]^{n_{R}} * \frac{1}{\mathrm{f}_{\mathrm{R}}}+\mathrm{k}_{\mathrm{OH}} * \frac{\left[\mathrm{OH}^{-}\right]^{\mathrm{n}_{\mathrm{OH}}}}{\mathrm{f}_{\mathrm{OH}}}
\end{aligned}
$$

$$
\begin{aligned}
& \mathrm{f}_{\mathrm{H}^{+}}=\left(1+\frac{[\mathrm{BC}]}{\mathrm{C}_{\mathrm{BC}, \mathrm{H}}}\right)^{\mathrm{x}_{\mathrm{H}}} *\left(1+\frac{\left[\mathrm{Al}^{3+}\right]}{\mathrm{C}_{\mathrm{Al}, \mathrm{H}}}\right)^{\mathrm{y}_{\mathrm{H}}} *\left(\left(1+\mathrm{K}_{\mathrm{Si}, \mathrm{H}} *\left(\frac{[\mathrm{Si}]}{\mathrm{C}_{\mathrm{Si}, \mathrm{H}^{+}}}\right)^{\mathrm{z}_{\mathrm{H}}}\right)\right. \\
& \mathrm{f}_{\mathrm{H}_{2} \mathrm{O}}=\left(1+\frac{[\mathrm{BC}]}{\mathrm{C}_{\mathrm{BC}, \mathrm{H}_{2} \mathrm{O}}}\right)^{\mathrm{x}_{\mathrm{H}_{2} \mathrm{O}}} *\left(1+\frac{\left[\mathrm{Al}^{3+}\right]}{\mathrm{C}_{\mathrm{Al}_{,} \mathrm{H}_{2} \mathrm{O}}}\right)^{\mathrm{y}_{\mathrm{H}_{2} \mathrm{O}}} *\left(\left(1+\mathrm{K}_{\mathrm{Si}_{,} \mathrm{H}_{2} \mathrm{O}} *\left(\frac{[\mathrm{Si}]}{\mathrm{C}_{\mathrm{Si}_{1} \mathrm{H}_{2} \mathrm{O}}}\right)^{\mathrm{z}_{\mathrm{H}_{2} \mathrm{O}}}\right)\right. \\
& \mathrm{f}_{\mathrm{CO}_{2}}=\left(1+\mathrm{K}_{\mathrm{CO}_{2}} * \frac{\mathrm{P}_{\mathrm{CO}_{2}}}{\mathrm{P}_{\mathrm{CO}_{2} \text { Limit }}}\right)^{\mathrm{n}_{\mathrm{CO}_{2}}} *\left(1+\frac{[\mathrm{BC}]}{\mathrm{C}_{\mathrm{BC}, \mathrm{CO}_{2}}}\right)^{\mathrm{x}_{\mathrm{CO}_{2}}} *\left(1+\frac{\left[\mathrm{Al}^{3+}\right]}{\mathrm{C}_{\mathrm{Al}, \mathrm{CO}_{2}}}\right)^{\mathrm{y}_{\mathrm{CO}_{2}}} \\
& *\left(1+\mathrm{K}_{\mathrm{Si}, \mathrm{CO}_{2}} *\left(\frac{[\mathrm{Si}]}{\mathrm{C}_{\mathrm{Si}, \mathrm{CO}_{2}}}\right)^{\mathrm{z}_{\mathrm{CO}_{2}}}\right)
\end{aligned}
$$

$$
\begin{aligned}
& \mathrm{f}_{\mathrm{R}}=\left(1+\frac{[\mathrm{R}]}{[\mathrm{R}]_{\mathrm{Limit}}}\right)^{\mathrm{n}_{\mathrm{R}}} *\left(1+\frac{[\mathrm{BC}]}{\mathrm{C}_{\mathrm{BC}, \mathrm{R}}}\right)^{\mathrm{x}_{\mathrm{R}}} *\left(1+\frac{\left[\mathrm{Al}^{3+}\right]}{\mathrm{C}_{\mathrm{Al}, \mathrm{R}}}\right)^{\mathrm{y}_{\mathrm{R}}} *\left(\left(1+\mathrm{K}_{\mathrm{Si}, \mathrm{R}} *\left(\frac{[\mathrm{Si}]}{\mathrm{C}_{\mathrm{Si}, \mathrm{R}}}\right)^{\mathrm{z}_{\mathrm{R}}}\right)\right. \\
& \mathrm{f}_{\mathrm{OH}^{-}}=\left(1+\frac{[\mathrm{BC}]}{\mathrm{C}_{\mathrm{BC}, \mathrm{OH}}}\right)^{\mathrm{x}_{\mathrm{OH}}} *\left(1+\frac{\left[\mathrm{Al}^{3+}\right]}{\mathrm{C}_{\mathrm{Al}, \mathrm{OH}}}\right)^{\mathrm{y} \mathrm{OH}} *\left(\left(1+\mathrm{K}_{\mathrm{Si}, \mathrm{OH}} *\left(\frac{[\mathrm{Si}]}{\mathrm{C}_{\mathrm{Si}, \mathrm{OH}^{-}}}\right)^{\mathrm{z}_{\mathrm{OH}}}\right)\right.
\end{aligned}
$$

where:

$\mathrm{C}_{\mathrm{BC}, \mathrm{i}}$ is the lower limiting base cation concentration in reaction $\mathrm{i}$, $\mathrm{C}_{\mathrm{Al}, \mathrm{i}}$ is the lower limiting aluminium concentration in reaction $\mathrm{i}$, 


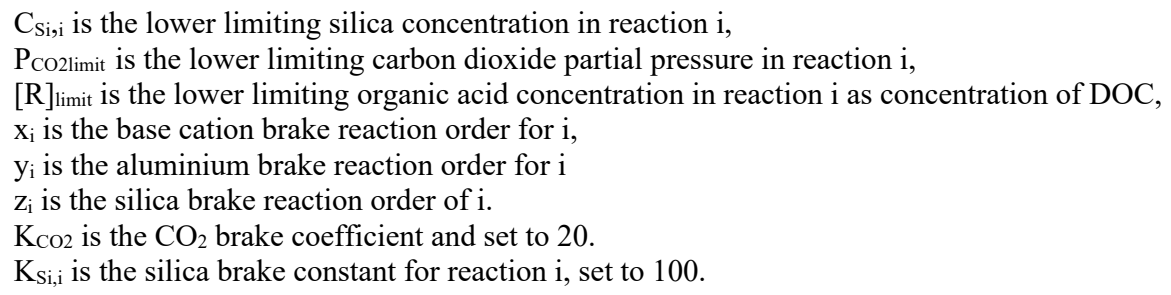

Table 2. Alteration series from muscovite, biotite and feldspars to clays, corresponding to Figure 11.

\begin{tabular}{|c|c|c|c|c|}
\hline \# & Mineral & Interlayer & Octahedral & Tetrahedral \\
\hline \multicolumn{5}{|c|}{ Muscovite pathway } \\
\hline 1 & Muscovite & $\mathrm{K}$ & $\mathrm{Al}_{2}$ & $\mathrm{Al}_{1.0} \mathrm{Si}_{3.0} \mathrm{O}_{10}(\mathrm{OH})_{2}$ \\
\hline 2 & Illite 1 & $\mathrm{~K}_{0.5} \mathrm{Mg}_{0.01} \mathrm{Ca}_{0.01} \mathrm{Al}_{0.05}$ & $\mathrm{Al}_{1.6} \mathrm{Fe}_{0.25} \mathrm{Mg}_{0.1} \mathrm{Ti}_{0.04}$ & $\mathrm{Al}_{0.6} \mathrm{Si}_{3.4} \mathrm{O}_{10}(\mathrm{OH})_{2}$ \\
\hline 3 & Illite 2 & $\mathrm{~K}_{0.44} \mathrm{Mg}_{0.01} \mathrm{Ca}_{0.01} \mathrm{Al}_{0.07}$ & $\mathrm{Al}_{1.6} \mathrm{Fe}_{0.25} \mathrm{Mg}_{0.1} \mathrm{Ti}_{0.04}$ & $\mathrm{Al}_{0.6} \mathrm{Si}_{3.4} \mathrm{O}_{10}(\mathrm{OH})_{2}$ \\
\hline 4 & Illite 3 & $\mathrm{~K}_{0.39} \mathrm{Mg}_{0.013} \mathrm{Ca}_{0.013} \mathrm{Al}_{0.06}$ & $\mathrm{Al}_{1.5} \mathrm{Fe}_{0.32} \mathrm{Mg}_{0.1} \mathrm{Ti}_{0.08}$ & $\mathrm{Al}_{0.6} \mathrm{Si}_{3.4} \mathrm{O}_{10}(\mathrm{OH})_{2}$ \\
\hline 5 & Illitic vermiculite & $\mathrm{K}_{0.35} \mathrm{Mg}_{0.03} \mathrm{Ca}_{0.03} \mathrm{Al}_{0.06}$ & $\mathrm{Al}_{1.63} \mathrm{Fe}_{0.32} \mathrm{Mg}_{0.08} \mathrm{Ti}_{0.07}$ & $\mathrm{Al}_{0.6} \mathrm{Si}_{3.4} \mathrm{O}_{10}(\mathrm{OH})_{2}$ \\
\hline 6 & Kaolinite & & & $\mathrm{Al}_{2.0} \mathrm{Si}_{2} \mathrm{O}_{5}(\mathrm{OH})_{4}$ \\
\hline \multicolumn{5}{|c|}{ Chlorite pathway } \\
\hline 1 & Chlorite & $\mathrm{Ca} 0.5 \mathrm{Mg}_{1.5}$ & $\mathrm{Al}_{1.0} \mathrm{Fe}_{0.5} \mathrm{Mg}_{1.5}$ & $\mathrm{Al}_{1.0} \mathrm{Si}_{3.0} \mathrm{O}_{10}(\mathrm{OH})_{2}$ \\
\hline 2 & Vermiculite 1 & $\mathrm{~K}_{0.32} \mathrm{Mg}_{0.07} \mathrm{Ca}_{0.09} \mathrm{Al}_{0.05}$ & $\mathrm{Al}_{1.52} \mathrm{Fe}_{0.35} \mathrm{Mg}_{0.1}$ & $\mathrm{Al}_{0.6} \mathrm{Si}_{3.4} \mathrm{O}_{10}(\mathrm{OH})_{2}$ \\
\hline 3 & Vermiculite 2 & $\mathrm{~K}_{0.30} \mathrm{Mg}_{0.05} \mathrm{Ca}_{0.05} \mathrm{Al}_{0.05}$ & $\mathrm{Al}_{1.55} \mathrm{Fe}_{0.32} \mathrm{Mg}_{0.05} \mathrm{Ti}_{0.06}$ & $\mathrm{Al}_{0.6} \mathrm{Si}_{3.4} \mathrm{O}_{10}(\mathrm{OH})_{2}$ \\
\hline 4 & Vermiculite 3 & $\mathrm{~K}_{0.25} \mathrm{Mg}_{0.04} \mathrm{Ca}_{0.04} \mathrm{Al}_{0.08}$ & $\mathrm{Al}_{1.55} \mathrm{Fe}_{0.32} \mathrm{Mg}_{0.05} \mathrm{Ti}_{0.06}$ & $\mathrm{Al}_{0.6} \mathrm{Si}_{3.4} \mathrm{O}_{10}(\mathrm{OH})_{2}$ \\
\hline 5 & $\mathrm{Al} / \mathrm{OH}$ interlayered vermiculite & $\mathrm{K}_{0.11} \mathrm{Mg}_{0.04} \mathrm{Ca}_{0.04} \mathrm{Al}_{0.1}$ & $\mathrm{Al}_{1.52} \mathrm{Fe}_{0.4 \mathrm{Mg}_{0.05} \mathrm{Ti}_{0.08}}$ & $\mathrm{Al}_{0.5} \mathrm{Si}_{3.5} \mathrm{O}_{10}(\mathrm{OH})_{2}$ \\
\hline 6 & Kaolinite & & & $\mathrm{Al}_{2.0} \mathrm{Si}_{2} \mathrm{O}_{5}(\mathrm{OH})_{4}$ \\
\hline \multicolumn{5}{|c|}{ Biotite pathway } \\
\hline 1 & Biotite & $\mathrm{K}_{1.0} \mathrm{Mg}_{2.0}$ & $\mathrm{Al}_{0.5} \mathrm{Fe}_{0.5} \mathrm{Mg}_{1.0}$ & $\mathrm{Al}_{1.0} \mathrm{Si}_{3.0} \mathrm{O}_{10}(\mathrm{OH})_{2}$ \\
\hline 2 & Vermiculite 1 & $\mathrm{~K}_{0.32} \mathrm{Mg}_{0.07} \mathrm{Ca}_{0.09} \mathrm{Al}_{0.05}$ & $\mathrm{Al}_{1.52} \mathrm{Fe}_{0.35} \mathrm{Mg}_{0.1}$ & $\mathrm{Al}_{0.6} \mathrm{Si}_{3.4} \mathrm{O}_{10}(\mathrm{OH})_{2}$ \\
\hline 3 & Vermiculite 2 & $\mathrm{~K}_{0.30} \mathrm{Mg}_{0.05} \mathrm{Ca}_{0.05} \mathrm{Al}_{0.05}$ & $\mathrm{Al}_{1.55} \mathrm{Fe}_{0.32} \mathrm{Mg}_{0.05} \mathrm{Ti}_{0.06}$ & $\mathrm{Al}_{0.6} \mathrm{Si}_{3.4} \mathrm{O}_{10}(\mathrm{OH})_{2}$ \\
\hline 4 & Vermiculite 3 & $\mathrm{~K}_{0.25} \mathrm{Mg}_{0.04} \mathrm{Ca}_{0.04} \mathrm{Al}_{0.08}$ & $\mathrm{Al}_{1.55} \mathrm{Fe}_{0.32} \mathrm{Mg}_{0.05} \mathrm{Ti}_{0.06}$ & $\mathrm{Al}_{0.6} \mathrm{Si}_{3.4} \mathrm{O}_{10}(\mathrm{OH})_{2}$ \\
\hline 5 & $\mathrm{Al} / \mathrm{OH}$ interlayered vermiculite & $\mathrm{K}_{0.1} \mathrm{Mg}_{0.04} \mathrm{Ca}_{0.04} \mathrm{Al}_{0.1}$ & $\mathrm{Al}_{1.52} \mathrm{Fe}_{0.4} \mathrm{Mg}_{0.05} \mathrm{Ti}_{0.08}$ & $\mathrm{Al}_{0.5} \mathrm{Si}_{3.5} \mathrm{O}_{10}(\mathrm{OH})_{2}$ \\
\hline 6 & Kaolinite & & & $\mathrm{Al}_{2.0} \mathrm{Si}_{2} \mathrm{O}_{5}(\mathrm{OH})_{4}$ \\
\hline \multicolumn{5}{|c|}{ Feldspar pathway } \\
\hline 1 & Feldspar & $\mathrm{K}, \mathrm{Na}, \mathrm{Ca}$ & & $\mathrm{Al}_{1} \mathrm{Si}_{3} \mathrm{O}_{8}$ \\
\hline 2 & Sericite & $\mathrm{Na}_{0.1} \mathrm{~K}_{0.75}$ & $\mathrm{Al}_{1.9} \mathrm{Mg}_{0.1}$ & $\mathrm{Al}_{0.84} \mathrm{Si}_{3.16} \mathrm{O}_{10}(\mathrm{OH})_{2}$ \\
\hline 3 & Sericitic vermiculite 1 & $\mathrm{~K}_{0.3} \mathrm{Mg}_{0.02} \mathrm{Ca}_{0.05}$ & $\mathrm{Al}_{0.02}$ & $\mathrm{Al}_{1.0} \mathrm{Si}_{3} \mathrm{O}_{10}(\mathrm{OH})_{2}$ \\
\hline 4 & Sericitic vermiculite 2 & $\mathrm{~K}_{0.1} \mathrm{Mg}_{0.05} \mathrm{Ca} 0.02$ & $\mathrm{Al}_{0.05}$ & $\mathrm{Al}_{1.0} \mathrm{Si}_{3} \mathrm{O}_{10}(\mathrm{OH})_{2}$ \\
\hline 5 & $\mathrm{Al} / \mathrm{OH}$ interlayered vermiculite & $\mathrm{K}_{0.1} \mathrm{Mg}_{0.04} \mathrm{Ca}_{0.04} \mathrm{Al}_{0.1}$ & $\mathrm{Al}_{1.52} \mathrm{Fe}_{0.4} \mathrm{Mg}_{0.05} \mathrm{Ti}_{0.08}$ & $\mathrm{Al}_{0.5} \mathrm{Si}_{3.5} \mathrm{O}_{10}(\mathrm{OH})_{2}$ \\
\hline 6 & Kaolinite & & & $\mathrm{Al}_{2.0} \mathrm{Si}_{2} \mathrm{O}_{5}(\mathrm{OH})_{4}$ \\
\hline
\end{tabular}

\subsection{Secondary phases in the soil}

A significant fraction of primary minerals dissolve incongruently to alteration minerals often referred to as secondary minerals and clays. Both terms are inconsistently used in the literature, and thus we define them as follows: We define clay minerals by their composition (kaolinite, gibbsite, quartz) and as listed in Table 3. This approach is thus not based on particle size, but on the molecular crystalline structure. Secondary minerals are formed in either two ways; a mineral that has been altered significantly in situ as is described in Table 2, for example when muscovite is altered through a series of illite and vermiculite phases and finally to kaolinite as the end product. Vermiculite, illite, montmorillonite are minerals of variable composition that are often called clays, In the soil, amorphous phases are composed of aluminium, silicate and soil organic substances. These amorphous phases slowly change composition as the organic matter decomposes and a more solid structure emerges. The alteration series from muscovite, biotite and feldspars to clays, are illustrated schematically in Figure 11 and listed in Table 2. The concept behind Table 2 is that as these minerals go through incongruent dissolution (alteration), they become depleted in certain ions (like $\mathrm{Ca}, \mathrm{Mg}, \mathrm{K}$ or $\mathrm{Na}$, and depending on $\mathrm{pH}$, in aluminium (at low $\mathrm{pH}$ ) or silica (at high $\mathrm{pH}$ ), but the crystal structure remains constant. Thus the crystal lattice destruction rate remains, but the base cation content of this structure becomes poorer, yielding less cations and less acidity neutralization. We have simplified this process down to 4 pathways, the muscovite pathway, the chlorite pathway, the biotite pathway and the feldspar pathway - see Table 2 . Muscovite changes through a series of alteration reactions to illite and finally to kaolinite. Chlorite alters to vermiculites and finally to kaolinite. Biotite goes through a series of alterations to vermiculite and kaolinite. 
Feldspars go through alterations, K-Feldspars through sericites and plagioclases to vermiculites (Holmqvist 2004, Holmqvist 2002, 2003).

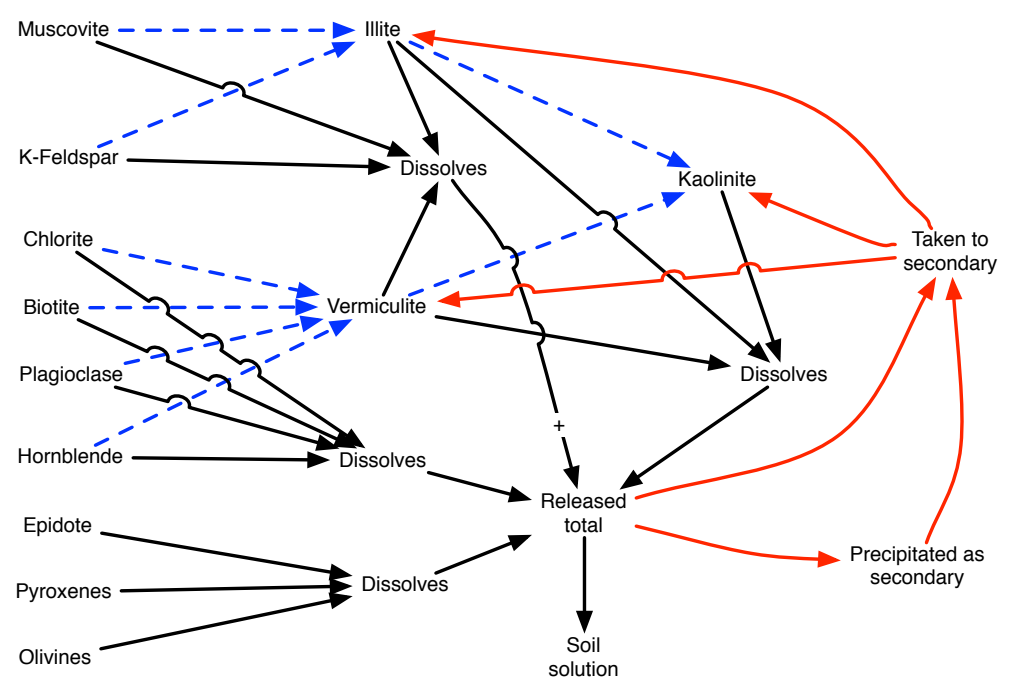

Figure 11. The alteration sequence developed for primary mineral towards alteration minerals, of which some are clay minerals. All minerals that dissolve contribute to the precipitation of secondary minerals.

\subsection{The parameterization of the kinetic rate equations}

The original PROFILE database had kinetic data for 59 different minerals, including about 25 different carbonates and some artificial silicates. New data from our own experiments (Sverdrup 1998, 1996, Sverdrup and Alveteg 1998, Holmqvist et al., 2002, 2003; Sverdrup and Holmqvist 2004) and from the literature ${ }^{2}$ have

${ }^{2}$ Examples are the following list of articles and studies we have used, but not limited to: Ajemba and Onokwuli 2012, Alekseyev 2007, Alexeyev et al., 1997, Amram and Ganor 2005, Amrhein and Suare 1992, Anbeek 1992a,b, Anbeek et al., 1994, Aradottir et al., 2013, Bandstra et al., 1998, Beig and Lüttge 2006, Bengtsson and Sjöberg 2009, Berg and Banwart 1994, 2000, Bibi et al., 2010, Bickmore et al., 2006, Blake and Walther 1996, Blum and Stillings 1995, Blum and Lasaga 1988, 1991, Blum 1994, Brady and Walther 1992, Bray et al., 2015, Brandt et al., 2005, Brantley 2003, 2008a,b, Brantley and Stillings 1994, 1996, Brantley and Chen 1995, Brantley and Conrad 2008, Brady and Walther 1992, Braun et al., 2016, Bray 2015, Cama et al., 2000, Carrol and Knauss 2005, Carrol and Walther 1990, Carrol and Smith 2013, Casetou-Gustafsson et al., 2018, Casey et al., 1991, Casey and Sposito 1992, Casey and Westrich 1992, Chaïrat et al., 2007, Chen and Brantley 1997, 1998, 2000, Chin and Mills 1991, Critelli et al., 2015, 2014, Cotton 2008, Crundwell 2013, 2014a,b,c,d, 2015a,b, 2017, Daval et al., 2010a,b, 2013, Devidal et al., 1997, Diedrich et al., 2014, Dixit and Carrol 2007, Dove and Crerar 1990, Dorozhkin 2012, Dresel 1989, Drever et al., 1994, 1996, Drewer and Clow 1995, Drewer and Zobrist 1992, Drever and Stillings 1997, Dorozin 2012, Duckworth and Martins 2003a,b, Fernandez-Bastero et al., 2008, Fischer and Liebscher 2014, Finlay et al., 2010, Fouda et al., 1996a,b, Frogner and Schweda 1998, Fumuto et al., 2001, Gahrke et al., 2005, Ganor et al., 2005, Gautier et al., 1994, Gislasson and Hans, 1987, Gislasson and Oelkers 2003, Gislasson et al., 1996, Godderis et al., 2006, Glover et al., 2003, Godderis et al., 2006, Golubev et al., 2004, 2005, Guidry and Mackenzie 2003, Goyne et al., 2006, Gudbrandsson et al., 2011, 2014, Gustafsson and Puigdomenech 2003, Hamilton et al., 2000, 2001, Hangx and Spiers 2009, Harouiya et al., 2007, Harouiya and Oelkers 2004, Haug et al., 2010, Hausrath et al., 2009, Hayashi and Yamada 1990, Helgeson et al., 1984, Hellmann 2007, 2006, 2010, Hilley et al., 2010, Holmqvist and Sverdrup 2001, Holmqvist et al., 1999, 2002, 2003, 2004, Hodson 2006a,b, Hodson and Langan 1999, Hodson et al., 1996, 1997, Hänchen et al., 2006, Huertas et al., 1999, 2001, Jin et al., 2011, Johnsson et al., 1992, Johnson et al., 2014, Jonckbloedt 1998, Jönsson et al., 1995, Kalinowski 1997, Kalinowsli and Schweda 1995, Kalinowski et al., 1998, Knauss et al., 1993, Køhler et al., 2003, 2005, Kuwahara 206a,b, 2008, Labat and Viville 2006, Lagache 1965, Langan et al., 1996a, b, Lartigue 1994, Lasaga 1995, 1998, Lowson et al., 2005, 2007, Lazaro et al., 2015, Lu et al., 2013, 2015, Ludwig et al., 2013, Maher 2010, Malmstrøm and Banwart 1997, Malmström et al., 1996, Maurice et al., 2002, Mazer and Walther 1994, McCourt and Hendershot 1992, Metz et al., 2005, Meyer 2014, Mongeon et al., 2007, Murakami et al., 1998, Murphy and Helgesson 1987, Murphy et al., 1992, 1996, Nagy 1995, Nagy and Lasaga 1992, Nagy et al., 1991, Navarre-Sitchler and Thyne 2007, Nesbitt et al., 1991, Nyström-Claesson and Andersson 1996, Numan and Weaver 1969, Oelkers 2001a,b,, Oelkers and Schott 1995a,b, 1998, 2001, Oelkers et al., 1994, 2008, Oelkers and Gislasson 2001, Olsen 2007, 2008, Olsson 2007, Opolot and Finke 2015, Oxburgh 1991, Oxburgh et al., 1994, Paces 1983, Palandri and Kharka 2004, Pokrowsky and Schott 2000a,b, 2002, Pokorowsky et al., 2004, Poulson et al., 1997, Prajapati et al., 2014, Price et al., 2005, Pigiobbe et al., 2009, Ragnarsdottir 1993, Ragnarsdottir and Graham 1996, Raschmann and Fedorockova 2008, Rietz 1995, Rimstidt et al., 2012, Ross 1969, Rosso and Rimstidt 1999, Rozalen et al., 2014, Running and Gower 1991, Saldi et al., 2007, Sanemasa and Katura 1973, Schnoor 1990, Schofield et al., 2015, Schott et al., 2009, 2012, Smith et al., 2013, Smits and 
been considered to upgrade this database for this study. Care of these new data we have obtained rate parameters for about 107 different silicate or aluminium minerals and 6 generic carbonates. Of these minerals, the regression of $\sim 20$ have yet to be published. In due time, these will get their own proper publications, it is beyond the scope of this study to do them in detail. Data and records from unpublished experiments and experiment evaluations by Sverdrup and Holmqvist are available on paper records held in a large number of binders at the Inland University of Applied Sciences, at Hamar, Norway. These data are no longer available in digital form due to computer system changes and data filing format changes that have occurred during the last 20 years. This documentation could be available in 1-2 years time, provided that funding for the redigitalization work can be obtained. Rather some selected examples are presented below. The estimation of rate parameters was performed using the complete rate equation 1 and equations 23-28. As such, for a successful regression of experimental data, the rate must be known, along with the concentrations of all reactants at the conditions that rate was observed including $\left[\mathrm{H}^{+}\right], \mathrm{pCO}_{2},[\mathrm{R}],\left[\mathrm{OH}^{-}\right]$, as well as the reaction products in solution potentially contributing to retarding the dissolution reaction; $\left[\mathrm{Ca}^{2+}\right],\left[\mathrm{Mg}^{2+}\right],\left[\mathrm{K}^{+}\right],\left[\mathrm{Na}^{+}\right],\left[\mathrm{Al}^{3+}\right],\left[\mathrm{Al}(\mathrm{OH})_{4}^{-}\right],\left[\mathrm{H}_{4} \mathrm{SiO}_{4}\right]$ (Sverdrup 1990, Sverdrup and Warfvinge 1995). The experiments must have been performed over sufficient reaction conditions for the parameters in Equation 29 to be estimated. In some cases, the data from different experimental studies were combined to determine rate parameters or a reaction orders. During the regression process, experimental studies with insufficient data or documentation were omitted, unless the gap could be bridged with reasonable assumptions. Data regression was performed by rearranging equation (22) to:

$$
\begin{aligned}
\mathrm{k}_{\mathrm{H}} * \frac{\left[\mathrm{H}^{+}\right]^{\mathrm{n}_{\mathrm{H}}}}{\mathrm{f}_{\mathrm{H}}}=\mathrm{r}_{\text {Observed }}-\left(\frac{\mathrm{k}_{\mathrm{H}_{2} \mathrm{O}}}{\mathrm{f}_{\mathrm{H}_{2} \mathrm{O}}}+\mathrm{k}_{\mathrm{CO}_{2}} * \frac{\mathrm{P}_{\mathrm{CO}_{2}}^{\mathrm{n}_{\mathrm{CO}_{2}}}}{1+\mathrm{K}_{\mathrm{CO}_{2}} *}\right. & \mathrm{P}_{\mathrm{CO}_{2}}^{\mathrm{n}_{\mathrm{CO}_{2}}} * \frac{1}{\mathrm{f}_{\mathrm{CO}_{2}}} \\
& \left.+\mathrm{k}_{\mathrm{R}} * \frac{[\mathrm{R}]^{n_{R}}}{1+\mathrm{K}_{\mathrm{R}} *[\mathrm{R}]^{n_{R}}} * \frac{1}{\mathrm{f}_{\mathrm{R}}}+\mathrm{k}_{\mathrm{OH}} * \frac{\left[\mathrm{OH}^{-}\right]^{\mathrm{n}_{\mathrm{OH}}}}{\mathrm{f}_{\mathrm{OH}}}\right)
\end{aligned}
$$

In the acid to neutral $\mathrm{pH}$ range, such as $\mathrm{pH}<7$, this equation can be simplified in most instances by removing the OH-reaction to get (Sverdrup 1990):

$$
\begin{aligned}
\mathrm{k}_{\mathrm{H}} * \frac{\left[\mathrm{H}^{+}\right]^{\mathrm{n}_{\mathrm{H}}}}{\mathrm{f}_{\mathrm{H}}}=\mathrm{r}_{\text {Observed }}-\left(\frac{\mathrm{k}_{\mathrm{H}_{2} \mathrm{O}}}{\mathrm{f}_{\mathrm{H}_{2} \mathrm{O}}}+\mathrm{k}_{\mathrm{CO}_{2}} * \frac{\mathrm{P}_{\mathrm{CO}_{2}}^{\mathrm{n}_{\mathrm{OO}_{2}}}}{1+\mathrm{K}_{\mathrm{CO}_{2}} * \mathrm{P}_{\mathrm{CO}_{2}}^{\mathrm{n}_{\mathrm{OO}_{2}}} * \frac{1}{\mathrm{f}_{\mathrm{CO}_{2}}}}\right. \\
\left.+\mathrm{k}_{\mathrm{R}} * \frac{[\mathrm{R}]^{n_{R}}}{1+\mathrm{K}_{\mathrm{R}} *[\mathrm{R}]^{n_{R}}} * \frac{1}{\mathrm{f}_{\mathrm{R}}}\right)
\end{aligned}
$$

and the in the acid $\mathrm{pH}$ range $(\mathrm{pH}<4)$, this may be reduced to:

$$
\mathrm{k}_{\mathrm{H}} * \frac{\left[\mathrm{H}^{+}\right]^{\mathrm{n}_{\mathrm{H}}}}{\mathrm{f}_{\mathrm{H}}}=\mathrm{r}_{\text {Observed }}
$$

By entering the concentrations of $\mathrm{H}^{+}$, base cations, aluminium and silica into these equations, we can determine the rate coefficient, $\mathrm{k}_{\mathrm{H}}$, and $\mathrm{f}_{\mathrm{H}+}$. When the experiment was performed in the absence of organic acids, as is often the case, Equation (29) reduces to:

$$
\mathrm{k}_{\mathrm{H}} * \frac{\left[\mathrm{H}^{+}\right]^{\mathrm{n}_{\mathrm{H}}}}{\mathrm{f}_{\mathrm{H}}}=\mathrm{r}_{\text {Observed }}-\left(\frac{\mathrm{k}_{\mathrm{H}_{2} \mathrm{O}}}{\mathrm{f}_{\mathrm{H}_{2} \mathrm{O}}}+\mathrm{k}_{\mathrm{CO}_{2}} * \frac{\mathrm{P}_{\mathrm{CO}_{2}}^{\mathrm{n}_{\mathrm{CO}_{2}}}}{1+\mathrm{K}_{\mathrm{CO}_{2}} * \mathrm{P}_{\mathrm{CO}_{2}}^{\mathrm{n}_{\mathrm{CO}_{2}}}} * \frac{1}{\mathrm{f}_{\mathrm{CO}_{2}}}\right)
$$

Wallander 2016, Smits et al., 2014, Soler et al., 2008, Stephens and Hering 2003, Stillings and Brantley 1995, Stillings et al., 1996, Stockmann et al., 2008, Stumm and Wollast 1990, Stumm and Wieland 1990, Sverdrup 1990, 1996a,b, 1998, 2009, Sverdrup and Bjerle 1982, Sverdrup and Alveteg 1998, Sverdrup and Holmqvist 2016, Sverdrup and Warfvinge 1992a,b, 1995, Sverdrup et al., 1986, 1987, 1995,a,b, 1998, 2002, 2006, 2008, 2010, Traven et al., 2005, Swoboda-Collberg and Drever 1993, Taylor et al., 1999, 2000, Taylor and Blum 1995, Taylor et al., 2017, Techer et al., 2007, Teir et al., 2007, Terry 1983a,b,c, Terry and Monhemius 1983, Thom et al., 2013, Valsami-Jones et al., 1998, Turpault and Trotignon 1994, Valsami-Jones et al., 1998, Voltini et al., 2012, Wang and Giammar 2012, Wang et al., 2017, Warfvinge and Sverdrup 1992,a,b,c,d, 1993, 1995, Warfvinge et al., 1987, 1992, 1993, 1996, 2000, Weissbart and Rimstidt 2000, Welch and Ullman 1993, 1996, 2000, Westrich et al., 1993, White and Brantley 1995, 2003, White and Blum 1995, White et al., 1999, Whitfield et al., 2009, 2010, Wogelius and Walther 1991, 1992, Wolff-Boenisch et al., 2004a,b, 2011, Wood et al., 1999, Xie and Walter 1994, Yadaw and Chakrapani 2006, Yadaw et al., 2000, Yang and Steefel 2008, Yoo et al., 2009, Yu et al., 2016, 2017, Zabowski et al., 2007, Zhang and Bloom 1999a,b, Zhang et al., 1996, 2015, Zhang et al., 2013, Zhang and Lüttge 2017, 2009a,b, Zhu et al., 2010, Zassi 2009, Zavodsky et al., 1995, Zysset and Schindler 1996). 
Some experiments were conducted at very low or with no dissolved $\mathrm{CO}_{2}$ present and with organic ligands absent. In such cases, Equation (29) reduces to (Sverdrup 1990, Chin et al., 1991):

$$
\mathrm{r}_{H}=\mathrm{k}_{\mathrm{H}} * \frac{\left[\mathrm{H}^{+}\right]^{\mathrm{n}_{\mathrm{H}}}}{\mathrm{f}_{\mathrm{H}}}=\mathrm{r}_{\text {Observed }}-\frac{\mathrm{k}_{\mathrm{H}_{2} \mathrm{O}}}{\mathrm{f}_{\mathrm{H}_{2} \mathrm{O}}}
$$

In this latter case, two reactions influence mineral dissolution rates: 1) the $\mathrm{H}^{+}$reaction, and 2) the water reaction. The variation of rates as a function of $\mathrm{pH}$ at such conditions consists of a 'flat part' where rates are controlled by the water reaction (Figure 12). At these conditions, by entering the concentrations of retarding base cations, aluminium and silica, the rate coefficients can be determined. In the semi-neutral region (pH 68), the expression may be a flat line and the rate expression is reduced to:

$\mathrm{r}_{\text {Observed }}=\frac{\mathrm{k}_{\mathrm{H}_{2} \mathrm{O}}}{\mathrm{f}_{\mathrm{H}_{2} \mathrm{O}}}+\mathrm{k}_{\mathrm{CO}_{2}} * \frac{\mathrm{P}_{\mathrm{CO}_{2}}^{\mathrm{n}_{\mathrm{CO}_{2}}}}{1+\mathrm{K}_{\mathrm{CO}_{2}} * \mathrm{P}_{\mathrm{CO}_{2}}^{\mathrm{n}_{\mathrm{CO}_{2}}}} * \frac{1}{\mathrm{f}_{\mathrm{CO}_{2}}}+\mathrm{k}_{\mathrm{R}} * \frac{[\mathrm{R}]^{n_{R}}}{1+\mathrm{K}_{\mathrm{R}} *[\mathrm{R}]^{n_{R}}} * \frac{1}{\mathrm{f}_{\mathrm{R}}}$

When neither organic ligands nor $\mathrm{CO}_{2}$ is present, and in the $\mathrm{pH}$ range of 6-8, this is reduced to:

$$
\mathrm{r}_{\text {Observed }}=\frac{\mathrm{k}_{\mathrm{H}_{2} \mathrm{O}}}{\mathrm{f}_{\mathrm{H}_{2} \mathrm{O}}}
$$

With only organic acid ligands but no $\mathrm{CO}_{2}$ present, and in the $\mathrm{pH}$ range of 6-8, the rate expression becomes:

$$
\mathrm{r}_{\text {Observed }}=\frac{\mathrm{k}_{\mathrm{H}_{2} \mathrm{O}}}{\mathrm{f}_{\mathrm{H}_{2} \mathrm{O}}}+\mathrm{k}_{\mathrm{R}} * \frac{[\mathrm{R}]^{n_{R}}}{1+\mathrm{K}_{\mathrm{R}} *[\mathrm{R}]^{n_{R}}} * \frac{1}{\mathrm{f}_{\mathrm{R}}}
$$

In the far alkaline region ( $\mathrm{pH} \mathrm{10-14),} \mathrm{where} \mathrm{we} \mathrm{may} \mathrm{assume} \mathrm{that} \mathrm{the} \mathrm{OH}$ - reaction will be dominant, the rate expression reduces to:

$$
\mathrm{k}_{\mathrm{OH}} * \frac{\left[\mathrm{OH}^{-}\right]^{\mathrm{n}_{\mathrm{OH}}}}{\mathrm{f}_{\mathrm{OH}}}=\mathrm{r}_{\text {Observed }}
$$

By entering the concentrations of base cations, aluminium and silica, $\mathrm{f}_{\mathrm{OH}}$ can be determined and the rate coefficient, $\mathrm{k}_{\mathrm{OH}}$, and reaction order, $\mathrm{n}_{\mathrm{OH}}$ be determined. The reaction order $\mathrm{n}_{\mathrm{H}}$ and the coupled $\mathrm{n}_{\mathrm{OH}}$ for the $\mathrm{H}^{+}$ and the $\mathrm{OH}^{-}$reaction is derived from plots of the rate versus the solution $\mathrm{pH}$

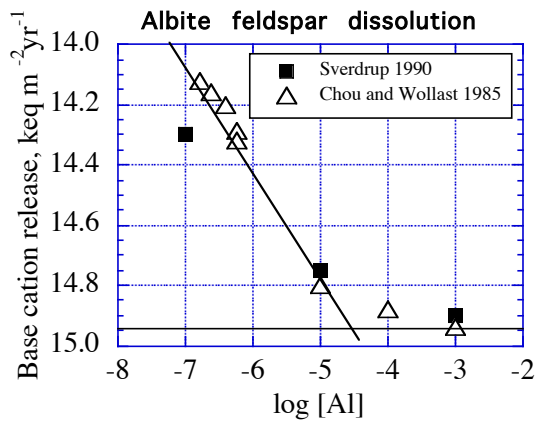

a

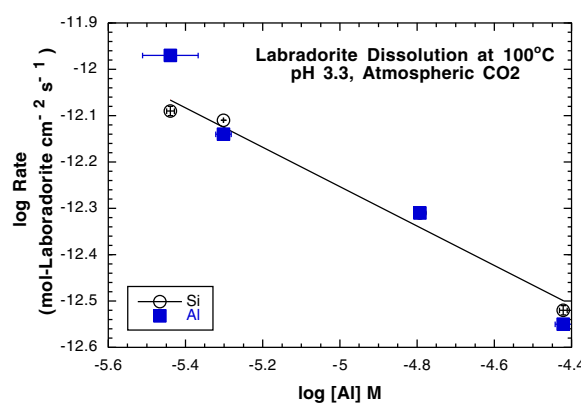

b

Figure 12. Regression plots showing the retarding or 'braking' effect of aluminium on the dissolution rate of albite. The figures were adapted from Sverdrup (1990). The decrease of rates as a function of aqueous aluminium concentration (the aluminium brake) is very prominent in the range of $\log \left[\mathrm{Al}^{3+}\right]$ from -7 to -4.5 . Aluminium concentrations are in $\mathrm{kmol} \mathrm{m}^{-3}$. The figures were adapted from (a) Sverdrup et al. (1990) and from (b) Carroll and Knauss (2001). For further information, see Sverdrup (1990) and Sverdrup and Warfvinge (1995). 


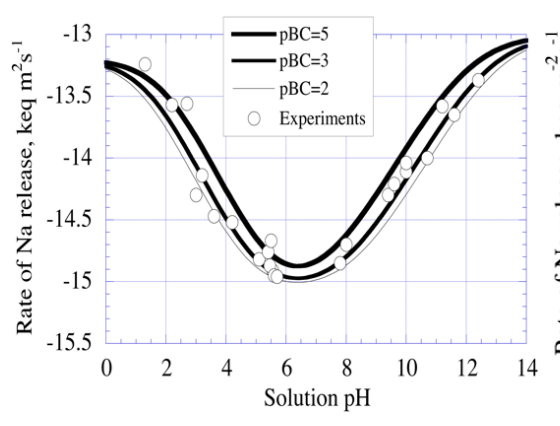

a

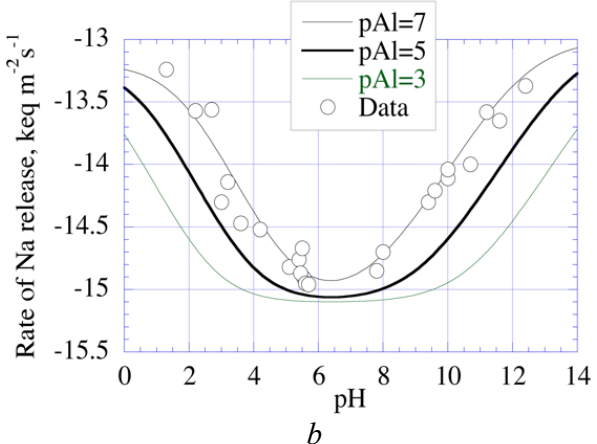

Figure 13. The effect on the base cation (a) and the aluminium concentration (b) on the dissolution rate of albite. (Sverdrup 1990). The circles represent the data from experiments, the solid lines the model simulations.

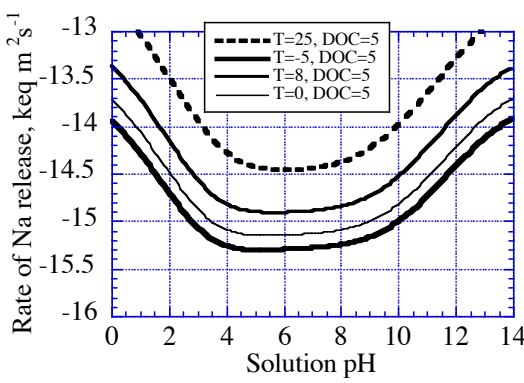

$a$

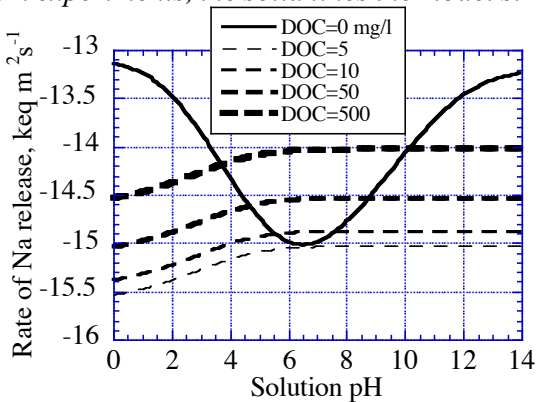

$b$

Figure 14. The effect on the base cation (a) and the aluminium concentration (b) on the dissolution rate of albite. The solid line is the reaction rate without $\mathrm{CO}_{2}$ or organic acid ligands.

Figure 13 shows diagrams used to quantify the retarding effect of aluminium on the dissolution rate of albite feldspar. The figures were adapted from Sverdrup (1990) and the work prepared for Sverdrup and Warfvinge (1995) and Sverdrup et al., (2009). Similar results for aluminium were found by Oelkers (2001), Oelkers and Gislasson (2001), Oelkers and Schott (2001, 1995a,b), Oelkers et al., (1999) for several minerals. The aluminium brake is very prominent in the range of log [Al] from -7 to -4.5 . For further information, see Sverdrup (1990) and Sverdrup and Warfvinge (1995).

The reaction order for the organic acid reaction is derived from experiments where only the concentration of organic ligand, $[R]$, has been varied. This was found to be $n_{R}=0.5$ on most experiments and this exponent value was universally adopted, suggesting a divalent ligand being the reactive agent (Sverdrup 1990, Sverdrup and Warfvinge 1995, Oelkers and Schott 1998).

The reaction order $\mathrm{n}_{\mathrm{CO} 2}$ for the reaction with $\mathrm{CO}_{2}$ is difficult to constrain, as very few experiments that allow it to be determined are available (Daval et al., 2013, Berg and Banwart 2000, Golubev et al., 2005, Fernandez-Bastero et al., 2008, Hangx and Spiers 2009, Lagache 1965, Wogelius and Walther 1991, WolffBoenisch et al., 2011, Stephens and Hering 2004, Sverdrup 1990). The few experiments that are available often gives conflicting results. Moreover, many experiments dealing with the effect of $\mathrm{CO}_{2}$ on weathering do not have the required resolution to allow data regression. For the minerals where the $\mathrm{CO}_{2}$ has little or no effect, this is fine, but for some it is. It was found to be $\mathrm{n}_{\mathrm{CO}_{2}}=0.6$ and was universally adopted. Sometimes these parameterizations can be determined by making single factor plots, but more often, the whole model must be used to recreate the experiments, taking many factors into account simultaneously. Figure 13 shows the effect on the base cation (a) and the aluminium concentration (b) on the dissolution rate of albite. Various plots were used to help data interpretation. Figure 14-15 illustrates how the model was used to plot different combinations of conditions, to investigate how distinct factors affect the weathering rates. The experimental data were overlaid in such diagrams (Figures 16-20) to help interpretation towards generating kinetic parameters (rate coefficients and reaction orders), for example the combination of different organic acid ligand concentrations and aluminium concentrations. The last diagram, on the lower right of Figure 15, shows the combination of different combinations of organic acid ligand concentrations and $\mathrm{CO}_{2}$ pressures in atmospheres. Figure 16 
shows the effect on rates of the base cation (a) and the aluminium concentration (b) on the dissolution rate for albite. The circles represent the data from experiments.

A further example of parameterization efforts is shown in Figure 16 for the case of hornblende dissolution rate data reported by from Holmqvist and Sverdrup (2004) and Holmqvist et al. (2002, 2003). Figure 16a and $16 \mathrm{~b}$ shows these data as a function of $\mathrm{pH}$. The figures were adapted from Holmqvist et al., 2003). Figure 16c shows the retarding effect of aluminium on the dissolution rate of hornblende, adapted from Holmqvist et al. (2003). Figure 16d shows a three-dimensional plot for the dissolution rate of hornblende, as a function of solution $\mathrm{pH}$ and aluminium concentration (Sverdrup, 1990).

In total, the dissolution rate of hornblende is defined by at least 8 and perhaps 9 different chemical factors including $\mathrm{pH}, \mathrm{Ca}+\mathrm{Mg}, \mathrm{K}, \mathrm{Na}, \mathrm{Al}, \mathrm{DOC}, \mathrm{CO}_{2}, \mathrm{Si}$ and sometimes Fe concentrations, and in addition to mineral surface area, soil wetting degree and temperature. For example changes in the aluminium concentration, can change the weathering rate by several orders of magnitude. Additional examples are presented in Figs. 17-21.
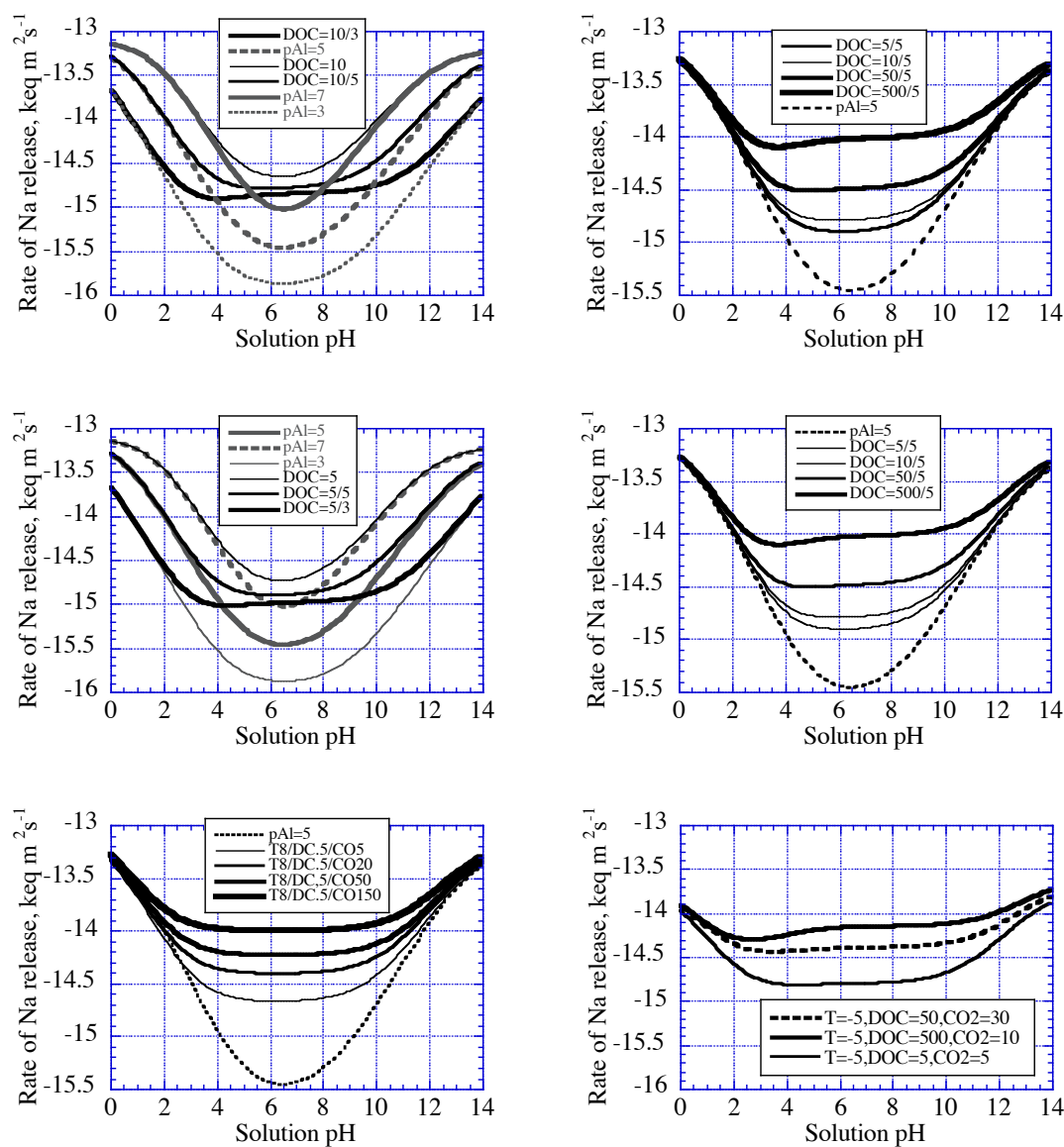

Figure 15. The weathering rate model was used to plot different combinations of conditions, to investigate the different shapes the weathering rate dependency can change (See Figure 7 and 9 for how the principle works). The experimental data were overlaid in such diagrams, to help retrieve kinetic parameters (e.g. rate coefficients and reaction orders). The last diagram, lower right, shows the combination of different combinations of organic acid ligand concentrations and $\mathrm{CO}_{2}$ pressures in atmospheres.

Figure 17 shows a typical example of data generated for different minerals during the 1996-2002 field seasons using a continuous, flow through, fluidized bed, with constant concentration feed solutions. Figure 18 shows the experimentally measured dissolution rates of epidote, after Holmqvist et al. (2003), as a function of $\mathrm{pH}$ according to a number of weathering experiments. 
https://doi.org/10.5194/bg-2019-464

Preprint. Discussion started: 27 March 2020

(c) Author(s) 2020. CC BY 4.0 License.
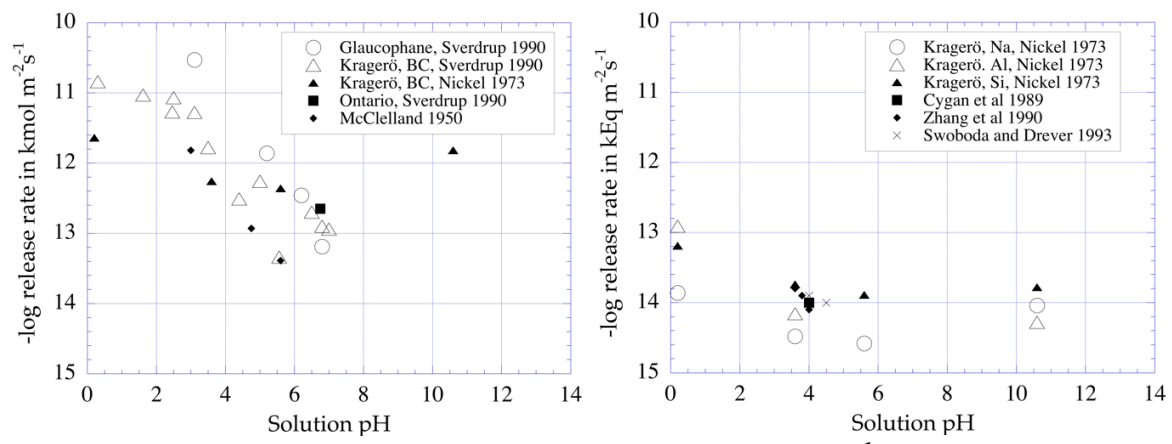

$a$
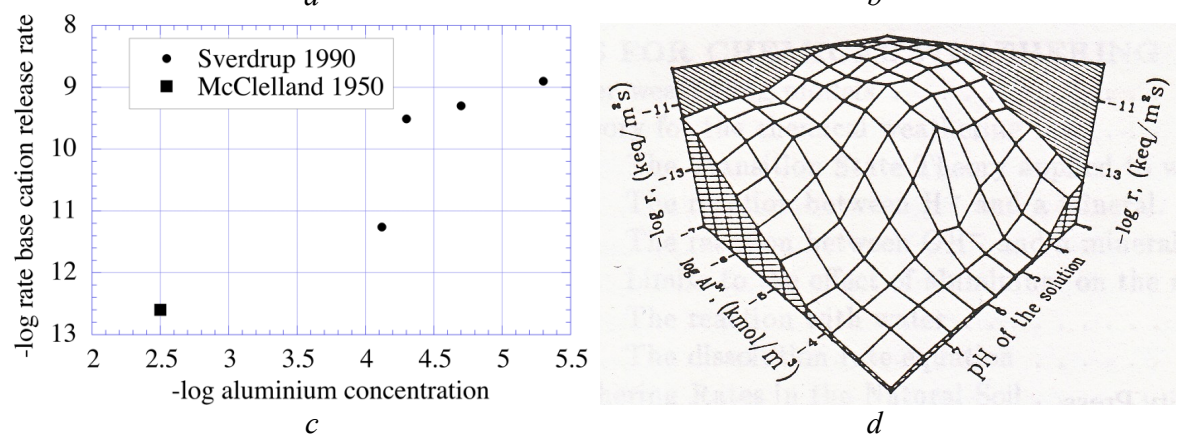

$c$

Figure 16. Diagram (a) shows the dissolution rate of minerals presented as base cation release rates as a function of $\mathrm{pH}$ and (b) shows the dissolution rate for hornblende as a function of solution $\mathrm{pH}$, but under different experimental conditions (Adapted from Sverdrup, 1990). Diagram (c) shows the retarding effect of aluminium on the dissolution rate of hornblende. (Adapted from Holmqvist et al., 2003). Diagram (d) shows a three-dimensional plot for the dissolution rate of hornblende, as a function of solution $\mathrm{pH}$ and aluminium concentration (Adapted from Sverdrup, 1990).

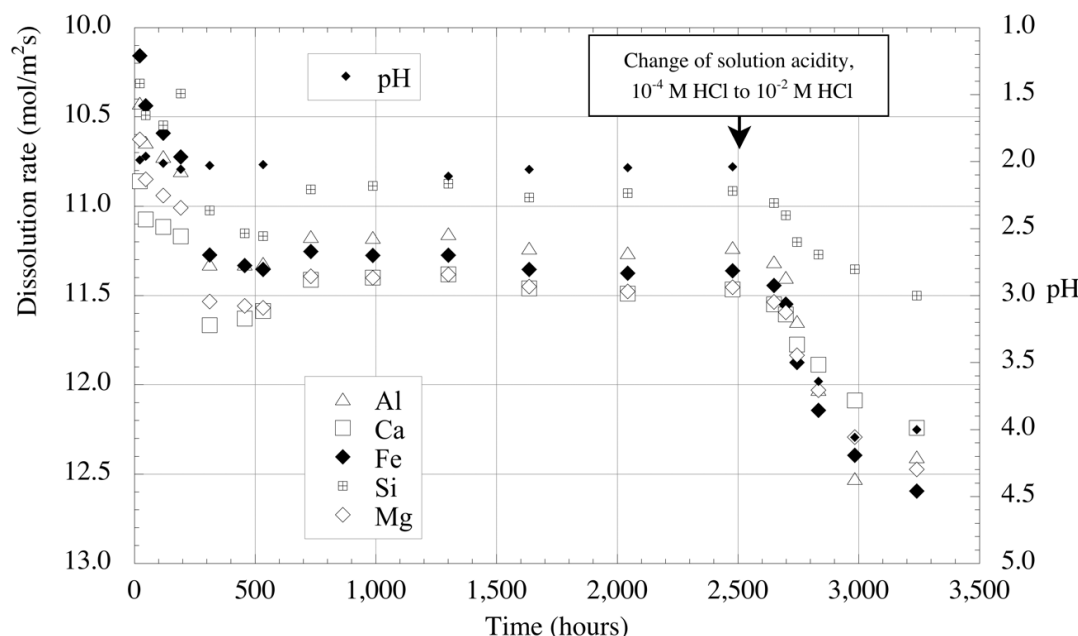

Figure 17. Typical example of dissolution rate data generated for epidote during 1996-2002 using a continuous, flow through, fluidized bed, with constant concentration feed solutions (Holmqvist 2002, 2003). All relevant constituents of the mineral were monitored in the aqueous solution in the experiment. 
https://doi.org/10.5194/bg-2019-464

Preprint. Discussion started: 27 March 2020

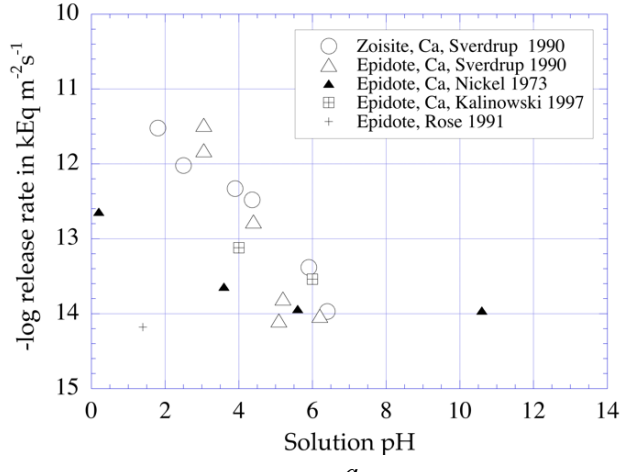

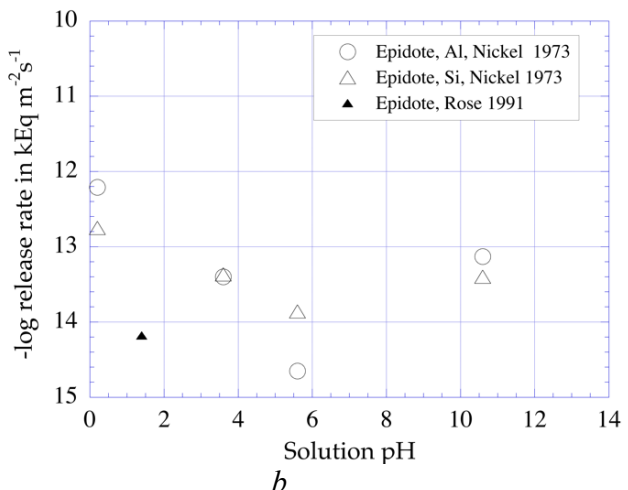

Figure 18. Epidote dissolution rate versus pH according to experiments reported by Holmqvist and Sverdrup and other literature sources data.

751

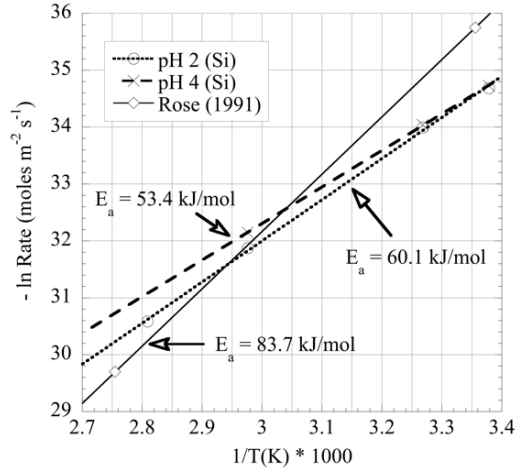

$a$

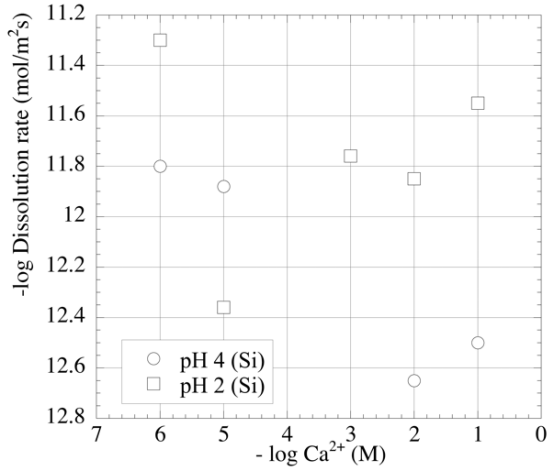

$b$

Figure 19. a) Estimates of the energy of activation for the dissolution of epidote. (b) the dependence of the rate of epidote on the calcium concentration at pH 2 and pH 4 (From one series of experiments by the authors).

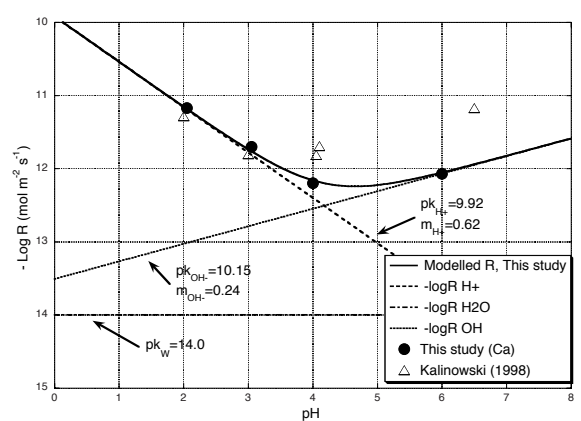

Figure 20. Hornblende dissolution rate data from Holmqvist and Sverdrup (2004) and Holmqvist et al, (2002, 2003) suggests that an arithmetic addition gives a good fit to the data. 

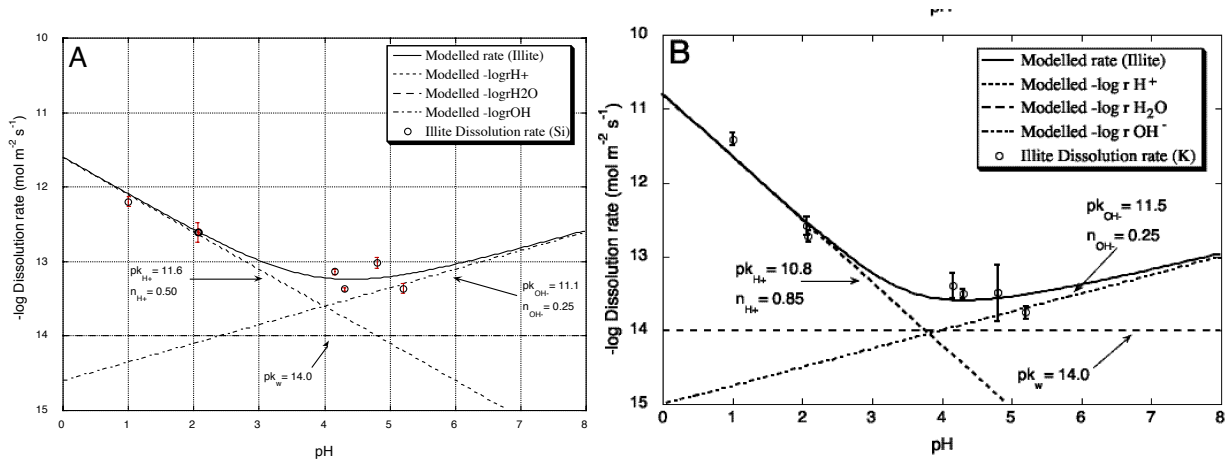

Figure 21. Diagram A show regression results from hornblende dissolution rates, diagram (B) shows regression results from a natural illite mineral dissolution extracted from an agricultural soil sample taken at the agricultural research site at Lanna, Uppsala, Sweden. Data from Holmqvist and Sverdrup (2004) and Holmqvist et al. (2002, 2003)

The release of all relevant ions was monitored by frequent sampling during the experiments. Figure 19a shows the activation energy for the dissolution of epidote. The dependence of the dissolution rate of epidote on the calcium concentration at pH 2 and pH 4 is shown in Figure 19b. Figure 20 and 21 shows data from Holmqvist and Sverdrup (2004) and Holmqvist et al. (2002, 2003) confirming that an arithmetic addition of the various rate contributions gives the best fit of the data, consistent with the principle shown in Figure 7. Figure 21 shows results from hornblende, the bottom diagrams (A, B) shows results from a natural illite mineral extracted from an agricultural soil sample taken at the agricultural research site at Lanna, Swedish Agricultural University, Uppsala, Sweden. Model lines were fitted to the data points to set the rate coefficients and reaction orders. Note that a complete set of kinetic parameters could not be directly generated for all minerals due to incomplete experimental data sets.

Estimates for some of the rate coefficients in Table 3 were based on mineral crystal structure analogies (Sverdrup 1990, Holmqvist 2003, Sverdrup and Stiernquist 2002, Crundwell 2014a,b, 2016), crystal bond energies (Sverdrup 1990, Velbel 1999, Crundwell 2014b, 2016) and comparison with analogue minerals. For many of the minerals, the dissolution kinetics patterns are very consistent. The dissolution rate curve shapes of feldspars, garnets, olivines, zoisites allow for this, but also muscovite to illite alteration series, K-feldspar to sericite alteration series.

For example, for the feldspars, we have sufficient data to parameterize the $\mathrm{H}^{+}$reaction for 5 different plagioclases, the mixed composition plagioclases from albite to anorthite. A plagioclase with a different composition will be interpolated between these as shown in Figure 22. We have the same situation for Kfeldpars with increasing contents of $\mathrm{Na}$ and $\mathrm{Ca}$, giving a systematic shift in parameter values. The pattern is very consistent as can be seen from the diagrams shown in Sverdrup (1990). However, for the $\mathrm{OH}^{-}$reaction we have less information. The $\mathrm{OH}^{-}$rate equation is theoretically linked to the $\mathrm{H}^{+}$reaction, but more sensitive to the concentration of the same base cation as in the mineral $(\mathrm{Na}, \mathrm{K}, \mathrm{Ca})$. With the available data and the theoretical link, we can estimate the missing parameters for some of the feldspars. There is a similar situation for the $\mathrm{H}_{2} \mathrm{O}$ reaction. We have the experiments that allow it to be constrained for most of the feldspars, and the shifts between the feldspars are systematic and consistent.

For the reaction with organic acid ligands, the situation is more complex. Many of the dissolution experiments run with organic acids were poorly documented, and getting accurate parameterization from them is not possible. For some minerals like feldspars and olivine, some experimental results are available (Stillings et al., 1996 is one example for feldspar) that allow for kinetic parameter estimation. They found $n_{R}=0.75$ in the range $\mathrm{pH} 3-7$. For other minerals, we have only single experiments, scattered among some few minerals. Few experiments are available, and for only a few types of minerals. These provide suggestions on what the parameter values probably would be. The situation is similar for the reaction between the mineral surface and $\mathrm{CO}_{2}$. The reaction seems to be weak, and only play a role at elevated pressures. For example, Wang (2013), based on the experimental results of Hänchen et al. (2006) concluded there was no effect of the $\mathrm{CO}_{2}$ reaction on olivine dissolution rates beyond the effect caused by $\mathrm{CO}_{2}$ on $\mathrm{pH}$.

Retrieved kinetic parameters are provided in Table 3. Parameters that are derived directly from of one or more set of experimental data are given in bold font. The kinetic parameters that were estimated are shown in roman font. The minerals in this table are divided into 11 groups of basic crystalline structures. Some of the 
minerals inside each group have large commonalities with respect to how they dissolve, and this was of great help in parameter estimation table.

For feldspars, nesosilicates and phyllosilicates, the amount of experimental data available makes the retrieved parameters robust. If three different compositions of basically the same type of mineral, $\mathrm{A}, \mathrm{B}$ and $\mathrm{C}$, are known to have relative rates $\mathrm{A}>\mathrm{B}>\mathrm{C}$, and we have the kinetic parameters for $\mathrm{A}$ and $\mathrm{C}$, then we can be fairly certain that the values for the kinetic parameters for B are constrained between A and C (see Figure 22). If they are close, then we would be able to set parameters for B fairly accurately, even with sparse experimental data for B. This is the case for many minerals (In particular feldspars, nesosilicates, phyllosilicates), and is a way to get more parameterization from limited experimental data sets. For the pyroxenes and amphiboles, the experiments indicate that the minerals behave with some variety depending on their composition, making the estimates less accurate. But, many pyroxenes are mixtures of definable end members and this was utilized to interpolate and estimate missing parameters.
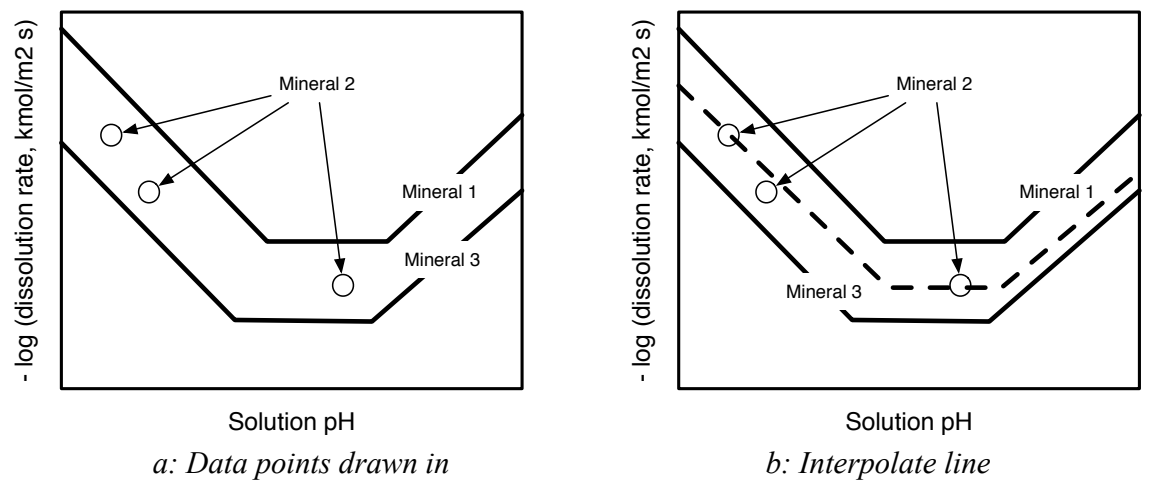

Figure 22. Some mineral groups have very similar dissolution rate behaviours. Such similarities can be used to interpolate between them (b) when we have intermediate minerals with only a few data points available (a).

Nevertheless all parameters in Table 3 together with their kinetic expressions should be further validated as additional experimental data become available. The ultimate test of the kinetics equations and parameters are how well they describe both laboratory experiments and field data where independent estimates of the weathering rate are available. Such tests have been generally successful (see the publications referred to earlier, and Erlandsson Lampa et al., 2016, 2019), suggesting that the combined methodology (experiments, analogues, interpolations, estimates based on theoretical rescaling, predictions made based on crystal bond energies) have captured the kinetics sufficiently well. More on this will be forthcoming in future publications.

\section{Results \\ 4.1. Kinetics and parameterization}

The tabulated kinetic coefficients are the major result of this report and they are provided in the Tables 1, 3 and 4. In total the dissolution kinetics parameterization for 112 minerals are provided. Erlandsson-Lampa et al. (this volume) tested the application of these values using the parameters on the Svartberget research site as a field evaluation.

The parameters in Table 3 are for a temperature of $8^{\circ} \mathrm{C}$ and standard atmospheric pressure.. The following default approximations were adopted due to the lack of data; $\mathrm{C}_{\mathrm{Al}}$ for the $\mathrm{H}^{+}$-reaction is taken to be equal to ${ }_{3}^{1 /}$ of the $\mathrm{C}_{\mathrm{Al}}$ for the $\mathrm{OH}^{-}$-reaction. $\mathrm{C}_{\mathrm{BC}}$ for the $\mathrm{H}^{+}$-reaction is taken to be ${ }_{3}^{1 /}$ of the $\mathrm{C}_{\mathrm{BC}}$ for the $\mathrm{OH}^{-}-$ reaction. The retarding reaction orders for base cations $(\mathrm{x})$, aluminium $(\mathrm{y})$ and silicate $(\mathrm{z})$ have been extracted from separate datasets and experiments where it was possible to separate out the effect of silicate alone, having subtracted the effect of base cations and aluminium first. Default values were computed and scaled with Madelung crystal lattice site energy (See Sverdrup 1990 and Velbel 1999 for how a-priori weathering rate coefficient estimates are made from crystal properties). Irreversible dissolution implies that the mineral cannot be formed from solution under soil conditions, and that there is no saturation concentration or back reaction. Pokrovsky and Schott (2000) and Rosso and Rimstidt (2000) reports a reaction order of $\mathrm{n}_{\mathrm{H}^{+}}=0.5$ for forsterite, but others report $\mathrm{n}_{\mathrm{H}^{+}}=1.0$ (Grandstaff 1986, Blum and Lasaga 1988, Siegel and Pfannkuch 1984, Sverdrup 1990). $\mathrm{n}_{\mathrm{H}+}=1.0$ seems to be a property of the nesosilicate group, but there is a possibility that presence of impurities such as pyroxenes or feldspars in the nesosilicate may give it a different crystal structure and thus a different $\mathrm{n}_{\mathrm{H}^{+}}$. Others, Berg and Banwart (2000), report $\mathrm{n}_{\mathrm{H}+}$ in the range 0.5 to 1 , depending on $\mathrm{pH}$. 
Table 4 shows the temperature dependencies of the dissolution rates. All variations of rates on temperature are computed using a modified Arrhenius equation (Sverdrup 1990, 1998, Sverdrup and Warfvinge 1988, 1992, 1995). Parameters for this equation generated from experimentally measured rates are shown in bold. Where experimental data were not available, estimates were computed and scaled with Madelung crystal lattice site energy from garnet (Sverdrup 1990, Velbel 1999). Values in normal font were estimated from the lattice energies and the properties of the mineral surface. Table 5 shows the stoichiometry

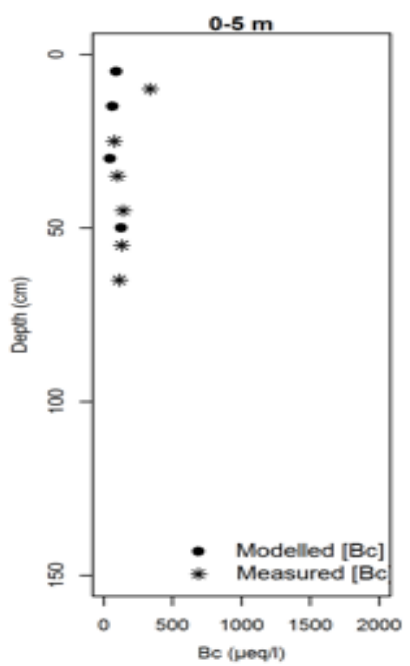

a

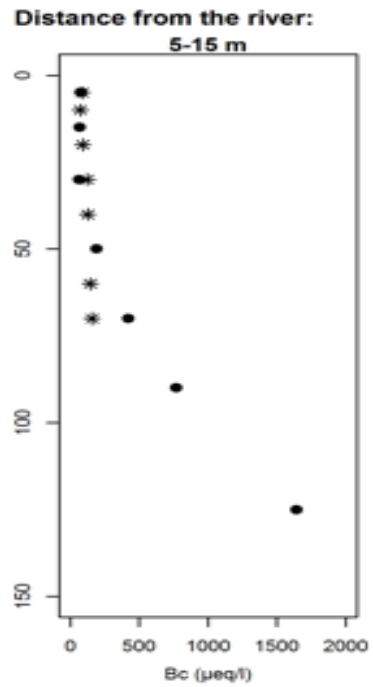

$b$

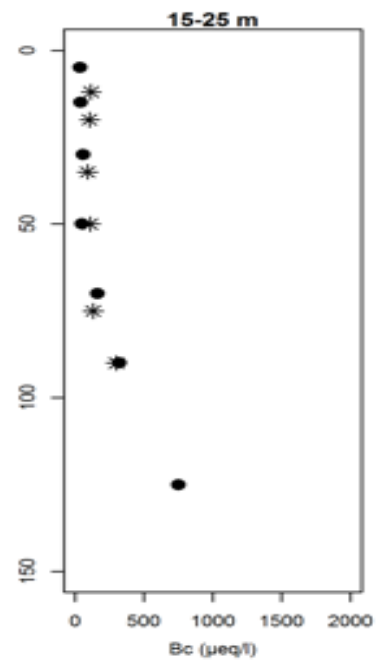

c

Figure 23. Comparison of calculated with measured base cation concentrations at the Svartberget field site, (Zanchi et al., 2016). Note the base cation concentrations ([Bc]) refer to the sum of the concentrations of $\mathrm{Na}$, $\mathrm{H}, \mathrm{Ca}$, and $\mathrm{Mg}$ in units of microequivalents per litre.

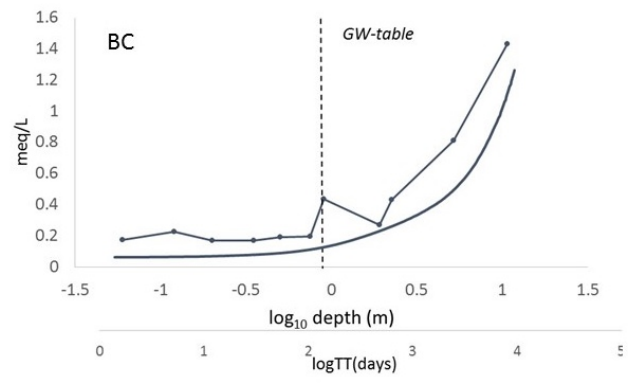

a: Base cations

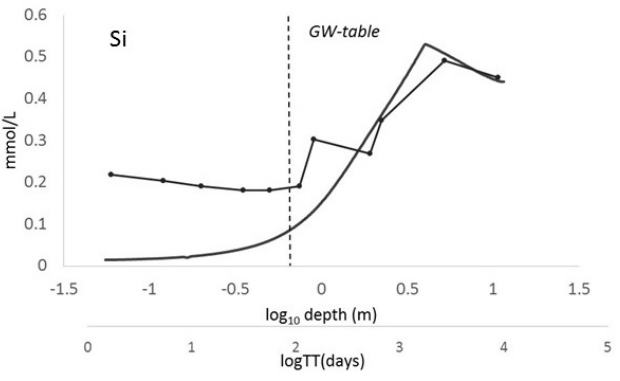

b: Silica

Figure 24. Modelled base cation (a) and $\mathrm{Si}$ (b) concentrations plotted against $\log _{10}$ of water transit time (smooth lines) at the Svartberget field site (See Erlandsson-Lampa et al., 2016, 2019 for a full description of the field test of the model). Overlain are the observed base cation and Si-concentrations from the soil profile, plotted against $\log _{10}$ of soil depth (straight lines with symbols).

\subsection{Testing the kinetic model}

The most recent comparison between the kinetic weathering model results and field observations follows in the article by Erlandsson-Lampa et al. (This issue). The research catchment where many of the model applications have been tested is located in Northern Sweden. A few examples are shown in Figure 23 and 24 . Figure 23 shows a comparison between calculated and observed base cation concentrations at the 
Svartberget research site. The model results reproduce the observed concentration pattern (Zanchi et al., 2016). Figure 23a shows the modelled base cation $(\mathrm{Bc})^{3}$ concentration and Figure $23 \mathrm{~b}$ shows the Si concentrations, plotted against $\log _{10}$ of water transit time (smooth lines). Overlaid are the observed Bc and Si-concentrations from the soil profile, plotted against $\log _{10}$ of soil depth (solid lines with markers) in Figure 23c. The weathering model considers all soil processes including ion exchange, vegetation interactions, decomposition of organic matter, water transport in the catchment in both the horizontal and vertical directions (Belyazid et al., 2004, 2011a,b, 2010a,b, 2015, 2019, Erlandsson-Lampa et al., 2019, Sverdrup et al., 1995, 2002). The model reproduces the observed field observations as a function of depth (Zanchi et al., 2016). The close correspondence between the calculated dissolved metal concentrations and the field observation are notable considering that we employed a silicate dissolution rate model based on laboratory measurements to determine the composition of the aqueous phase in the soil.

\subsection{Discussion}

The detailed comparisons between laboratory measured and field determined weathering rates generated using the kinetic models described above coupled to soil processes performed using PROFILE and ForSAFE stand out in stark contrast to the traditional geochemical models, which give results that are several orders of magnitude different from field observations (Erlandsson-Lampa et al., 2019). It was discovered that past efforts to describe field weathering rates using laboratory measured dissolution rates without consideration of the coupling of rates to the major soil processes yielded inaccurate results - see Erlandsson Lampa et al. (2016) and Nyström-Claesson and Andersson, (1996). Such observations demonstrate a need to take into account the complete set of processes occurring in the soil. Note that the mineral dissolution 'brake functions' used in this approach act differently on the weathering rates that the equilibrium expressions used in earlier models (Aagaard and Helgeson 1982, Murphy et al., 1987, Alekseyev et al., 1997, 2004, 2007, Oelkers, 2001, Oelkers et al., 1994, 2001, 2008). The preference for using the brakes rather than the traditional rate expression based on a slowing of rates as equilibrium is approached between the surface and the liquid is that equilibrium is not approached for many primary silicate minerals and thus the weathering process is irreversible.

\section{Conclusions}

The complex nature of weathering in the field is nearly impossible to interpret without a comprehensive model for the whole process. A first step to such interpretations can be the quantitative description of the dissolution rates of the major rock forming minerals. Even the dissolution rates of an individual mineral can involve several simultaneous reactions. Thus, experimentally measured rates results can only be accurately interpreted when a full system model is used. Under field conditions, mineral dissolution is coupled to other soil processes, and thus a full ecosystem system model is needed for their interpretation. The apparent difference between field and laboratory dissolution rates arise from the coupling of these processes, and disappear once a full model is employed. Use of a fully coupled model shows these differences to be negligible (Keegan and Laskow-Lehey 2014).

Taking account the vast literature reporting experimentally measured mineral dissolution rates, it was possible to create a fully parameterized kinetic database for about 100 minerals. About $40 \%$ of the kinetic parameters were determined directly from experiment interpretations, and the rest were determined from intermineral interpolations and using of analogues.

The adjustment of the aluminium 'brake function' and the introduction of a silica "brake function" as described in this work were necessary to improve the description of weathering rates in the lower part of the soil, below 1 meter depth. The test at the Svartberget catchment suggests that this revised mineral dissolution model works adequately as can be seen from Figures 24-25.

\section{Acknowledgements}

This work is based upon that of Prof. Dr. Harald Sverdrup and Prof. Dr. Per Warfvinge who initiated the new model approaches in the 1980's., Since then major contributions have been made by Dr. Matthias Alveteg (Uncertainty, programming the code), Prof. Per Warfvinge (Programming the code), Dr. Cecilia Akselsson (Regional parameterizations, geostatistics), Dr. Salim Belyazid (Programming the code, applying the model) and Daniel Kurz (Adaption of the mineral stoichiometry, adaptation to Switzerland). Dr. Johan Holmqvist and Harald Sverdrup were instrumental in taking up a second long campaign in weathering experiments, generating more kinetic data during 19972004. Dr. Johan Holmqvist carefully worked out the geostatistics of landscape sampling and robustness of regional parameterizations and creating geostatistically sound regional weathering rate maps), Dr. Salim Belyazid is the present head code editor of the PROFILE and ForSAFE models. 
This study was a part of the QWARTZ Project, coordinated by Prof. Kevin Bishop, Uppsala University, Sweden. Dr. Salim Beliazid, Natural Geography and Quaternary Geology, Stockholm University, Sweden, Dr. Martin Erlandsson Lampa, Institute of Hydrology, University of Uppsala, Sweden, Dr. Cecilia Akselsson, Earth Sciences, Lund University, Lund, Sweden, Daniel Kurz, EKG Geoscience, Bern, Switzerland, Dr. Max Posch, CCE, RIVM, Bilthoven, Netherlands, Dr Julian Aherne, Ecology, University of Trent, Canada, Dr. Jennifer Phelan, RTI Inc, Triangle Park, North Carolina, United States of America and Professor Harald Sverdrup, Industrial Engineering, University of Iceland, Reykjavik, Iceland (Earlier at Lund University) took part in the parameterization workshops, with the aim to have this updated kinetics database completed.

Professor Dr. Eric Oelkers was external advisor to the project, which turned out to be a good choice. $\mathrm{He}$ participated very willingly, eagerly and with excellent advice to the research process and in writing this paper.

\section{References}

Aagard, P. and H. C. Helgeson, Thermodynamic and kinetic constraints on reaction rates among minerals and aqueous solutions: I Theoretical considerations. American Journal of Science 282: 237-285. 1982.

Adebayo, A.O., Ipinmoroti, K.O., Ajayi, O.O., Dissolution Kinetics of Chalcopyrite with Hydrogen Peroxide in Sulphuric acid Medium Chem. Biochem. Eng. Q. 17, 213-218. 2003

Ajemba, R.O., and Onukwuli, O.D. Dissolution kinetics and mechanisms of reaction of Udi clay in nitric acid solution American Journal of Scientific and Industrial Research. 3, 115-121. 2012

Alekseyev, V.A. Equations for the Dissolution Reaction Rates of Montmorillonite, Illite, and Chlorite. Geochemistry International, 45: 770-78. 2007

Alekseyev, V.A., Medvedeva, L.S., Prisyagina, N.I., Meshalkin, S.S., Balabin, A.I. Change in the dissolution rates of alkali feldspars as a result of secondary mineral precipitation and approach to equilibrium. Geochimica et Cosmochimica Acta 61, 11251142. 1997

Akselsson, C., Holmquist, J., Alveteg, M., Kurz, D., Sverdrup, H.. Scaling and mapping regional calculations of soil chemical weathering. Water, Air and Soil Pollution Focus 4:671-681. 2004

Akselsson, C., Sverdrup, H., Holmqvist, J. Estimating weathering rates of Swedish forest soils in different scales, using the PROFILE model. Journal of Sustainable Forestry. 21:119-131. 2005

Akselsson, C., Holmqvist, J., Kurz, D., Sverdrup, H. Relations between elemental content in till, mineralogy of till and bedrock mineralogy in the province of Småland, Southern Sweden. Geoderma 136:643-659. 2006

Akselsson, C, and Sverdrup, H. Uthålligt skogsbruk i Sverige-räcker baskajonvittringen till?. In: Melkerud, P., Markdagen 2004, Nytt från forskningsfronten. 43-50. 2004

Akselsson, C., Westling, O., Sverdrup, H., Holmqvist, J., Thelin, G., Uggla, E., Malm, G. Impact of harvest intensity on long term base cation budgets in Swedish forest soils. Water, Air and Soil Pollution: Focus 7:201-210. 2007

Akselsson, C., Westling, O., Sverdrup, H., Holmqvist, J., Thelin, G., Uggla, E., Malm, G. Impact of Harvest Intensity on Long-Term Base Cation Budgets in Swedish Forest Soils. Water, Air, and Soil Pollution: Focus 7: 201-210. 2007

Akselsson, C., Fölster, J., Rapp, L., Alveteg, M., Belyazid, S., Westling, O., Sverdrup, H., Stendahl, J. Bara naturlig försurning. Underlagsrapport reviderade beräkningar av kritisk belastning för försurning. I: Naturvårdsverkets Rapport 5780, Bara naturlig försurning Bilagor til underlagsrapport fördjupad utvärdering av miljömålen, Bilaga 7:103-147. 2007

Akselsson, C., Westling, O., Alveteg, M., Thelin, G., Fransson, A.M., Hellsten, S., The influence of N load and harvest intensity on the risk of P limitation in Swedish forest soils. Science of the Total Environment. 404, 284-289. 2008

Akselsson, C., Westling, O., Alveteg, M., Thelin, G., Fransson, A-M., Hellsten, S., The influence of N load and harvest intensity on the risk of P limitation in Swedish forest soils. Science of The Total Environment. 404, 284-289. 2008

Akselsson, C., Belyazid, S. Critical biomass harvesting - Applying a new concept for Swedish forest soils. Forest Ecology and Management 409, 67-73. 2018

Akselsson, C., Olsson, J., Belyazid, S., René Capell, R. Can increased weathering rates due to future warming compensate for base cation losses following whole-tree harvesting in spruce forests? Biogeochemistry 128:1-2, 89-105. 2016

Albin, S., Building a system dynamics model; Part 1; Conceptualization. MIT System Dynamics Education Project (J. Forrester (Ed)) MIT, Boston. 34pp. https://ocw.mit.edu/courses/sloan-school-of-management/15-988-system-dynamics-self-study-fall-1998spring-1999/readings/building.pdf. 1997

Alveteg, M., and Sverdrup, H. Gothenburg Protocol: Uncertainty as to effects, Acid News 2, June 2000.

Alveteg, M., Sverdrup, H., Warfvinge. P., Regional assessment of dynamic aspects of soil acidification in southern Sweden. Water, Air and Soil Pollution 85:2509-2514. 1996

Alveteg, M., Walse, C., Sverdrup, H. Evaluating simplifications used in regional applications of SAFE and MAKEDEP models. Ecological Modelling 107:265-277. 1998

Alveteg, M., Barkman, A., Sverdrup, H. Integrated Environmental Assessment Modelling - Uncertainty in Critical Load Assessments. Final Report of the Swedish Subproject, EU/LIFE project. Reports in Ecology and Environmental Engineering 2000:1-163.

Alveteg, M., Sverdrup, H., Warfvinge, P. 1995 Developing a kinetic alternative in modelling soil aluminum. Water, Air and Soil Pollution, 79:377-389

Ameli, A.A., Beven, K., Erlandsson, M., Creed, I.F., McDonnell J.J., Bishop, K. Primary weathering rates, water transit times, and concentration-discharge relations: A theoretical analysis for the critical zone, Water Resources Research 53, 942-960, 2017

Amram, K. and Ganor, J. The combined effect of $\mathrm{pH}$ and temperature on smectite dissolution rate under acidic conditions. Geochimica et Cosmochimica Acta 69, 2535-2546. 2005

Amrhein, C. and Suarez, D.L. Some factors affecting the dissolution kinetics of anorthite at $258 \mathrm{C}$. Geochimica et Cosmochimica Acta 56, 1815-1826. 1992

Anbeek, C. The dependence of dissolution rates on grain size for some fresh and weathered feldspars. Geochimica et Cosmochimica Acta 56, 3957-3970. 1992a

1002

Anbeek, C. Surface roughness of minerals and implications for dissolution studies. Geochimica et Cosmochimica Acta 56, 14611469. $1992 b$ 
Anbeek, C., van Breemen N., Meijer E.L., van der Plas, L. The dissolution of naturally weathered feldspar and quartz. Geochimica et Cosmochimica Acta 58, 4601-4614. 1994

Andersson, B., Bishop, K., Borg, G.C., Gielser, R., Hultberg, H., Huse, M., Moldan, F., Nyberg, L., Nygaard, P.H., Nyström, U. The covered catchment site: A description of the physiography, climate and vegetation of three small coniferous forest catchments at Gårdsjön, South-west Sweden. In: Hultberg H. and Skeffington R. (Eds.) Experimental reversal of acid rain effects; The Gårdsjön roof project: 25-70. John Wiley Science. 1998

Aradottir, E.S.P, Sigfusson, B., Sonnenthal, E.L, Björnsson, G., Jonsson, H. Dynamics of basaltic glass dissolution - Capturing microscopic effects in continuum scale models. Geochimica et Cosmochimica Acta 121: 311-327. 2013.

Augustin, F., Houle, D., Gagnon, C., Courchsne, F. Evaluation of three methods for estimating rates of base cations in forested catchments. Catena 144, 1-10, 2006.

Ballesta, R., Cabrero, B., Sverdrup, H., Critical loads for different soils of the Mediterranean environment. The Science of the Total Environment 181:65-71. 1996

Balogh-Brunstad, Z., Keller, C.K., Bormann, B.T., O’Brien, R., Wang, D., Hawley, G. Chemical weathering and chemical denudation dynamics through ecosystem development and disturbance, Global Biogeochem. Cycles, 22, GB1007, doi:10.1029/2007GB002957. 2008

Bandstra, J.Z., Buss, H.L., Campen, K., Liermann, L.J., Moore J., Hausrath, E.M., Navarre, A.K., Jang, J-H., Brantley, S.L. Appendix: Compilation of Mineral Dissolution Rates, in Kinetics of Water-Rock Interaction, S. L. Brantley, J. D. Kubicki and A. F. White (eds.). Springer, New York, 731-808. 1998

Barkman, A., Schlyter, P., Lejonklev, M., Alveteg, M., Warfvinge, P., Sverdrup, H., Arnström T. Uncertainties in high resolution critical load assessment for forest soils - possibilities and constraints of combining distributed soil modelling and GIS. Environmental and Geographical Modeling, 3:2:125-143, 1999

Barkman, A., and Sverdrup, H., Critical loads of acidity and nutrient imbalance for forest ecosystems in Skåne. Reports in Environmental Engineering and Ecology, 1:96, Chemical Engineering II, Box 124, Lund University. 22100 Lund, Sweden, 1996

Barkman, A., and Alveteg, M., Identifying potentials for reducing uncertainty in critical load calculations using the PROFILE model. Water, Air and Soil Pollution. 125, 35-54 2001.

Beig M.S., and Lütttge A. Albite dissolution kinetics as a function of distance from equilibrium: implications for natural feldspar weathering. Geochimica et Cosmochimica Acta 70:1402-1420. 2006

Bélanger, N., Côté, B., Courchesne, F., Fyles, J.W., Warfvinge, P. and Hendershot, W. H. Simulation of soil chemistry and nutrient availability in a forested ecosystem of southern Quebec. I. Reconstruction of time-series files of nutrient cycling using the MAKEDEP model. Environ. Model. Soft. 17: 427-445. 2002a

Bélanger, N., Courchesne, F., Côté, B., Fyles, J.W., Warfvingue, P., Hendershot, W.H. Simulation of soil chemistry and nutrient availability in a forested ecosystem of southern Quebec. Part II. Application of the SAFE model. Environ. Mod. Soft. 17: 447-465. 2002b.

Belyazid, S., Sverdrup, H., Alveteg, M. The biogeochemical models family of the biogeochemistry group at Lund University. Proceedings from a UN/ECE conference held in Pushino, Russia September 16-18, 2004. Institute of Soils Science and Phyotobiology, Nauka, September 2004.

Belyazid, S, Westling, O. Sverdrup: H. Modelling changes in soil chemistry at 16 Swedish coniferous forest sites following deposition reduction. Environmental Pollution 144:596-609. 2006

Belyazid, S., Bailey, S., Sverdrup H. Past and Future Effects of Atmospheric Deposition on the Forest Ecosystem at the Hubbard Brook Experimental Forest: Simulations with the Dynamic Model ForSAFE In: Modelling of Pollutants in Complex Environmental Systems, Volume II: 357-377, Hanrahan. G. (Ed.) ILM Publications, International Labmate Limited. 2010

Belyazid, S., Sverdrup, H., Kurz, D., Braun, S. Exploring ground vegetation change for different scenarios and methods for estimating critical loads for biodiversity using the ForSAFE-VEG model in Switzerland and Sweden. Water, Air and Soil Pollution, 216:289-317. 2011

Belyazid, S., Kurz, D., Braun, S., Sverdrup, H., Rihm, B., Hettelingh, J.P. A dynamic modelling approach for estimating critical loads of nitrogen based on plant community changes under a changing climate. Environmental Pollution 159:789-801. 2011

Belyazid' S., Phelan' J., Clark' C., Sverdrup' H., Nihlgård'B., Driscoll C., Fernandez' I., Robin Dennis, R., Aherne' J. Assessing the effect of climate and air pollution on plant diversity and biogeochemistry in the Northeastern US broadleaf forests testing the ForSAFE-VEG model at three sites. In press Water, Air and Soil Pollution. 2015

Belyazid, S., Kurz, D., Braun, S., Sverdrup, H., Rihm, B., Hettelingh, J.P. A dynamic modelling approach for estimating critical loads of nitrogen based on plant community changes under a changing climate. Environmental Pollution 159:789-801. 2011

Belyazid, S., Bailey, S., Sverdrup H. Past and Future Effects of Atmospheric Deposition on the Forest Ecosystem at the Hubbard Brook Experimental Forest: Simulations with the Dynamic Model ForSAFE In: Modelling of Pollutants in Complex Environmental Systems, Volume II: 357-377, Hanrahan. G. (Ed.) ILM Publications, International Labmate Limited. 2010

Belyazid, S., Sverdrup, H., Akselsson, C., Kurz D. Synergies and conflicts in addressing climate change and nitrogen deposition in terrestrial ecosystems. Proceedings from the Nitrogen 2011 Conference held at the Edinburgh International Conference Centre. 11-14 April 2011. Edited by M. Sutton. http://www.nitrogen2011.org/ oral presentations/S17 2 Belyazid.pdf 2011.

Belyazid, S., Sverdrup, H.U., Kurz, D., Braun, S. Use of an integrated deterministic soil-vegetation model to assess impacts of atmospheric deposition and climate change on plant species diversity. In W. de Vries, J-P. Hettelingh, M. Posch (Eds) Critical Loads and Dynamic Risk Assessments: Nitrogen, Acidity and Metals in Terrestrial and Aquatic Ecosystems: 327-358. Springer Verlag. 2015.

Belyazid, S..; Phelan; J., Nihlgård; B., Sverdrup; H., Driscoll; C. Fernandez; I., Aherne; J., Teeling-Adams, L.M., Arsenault; M., Cleavitt; N., Engstrom; B., Dennis; R., Sperduto; S., Werier; D., Clark, C. Assessing the Effects of Climate Change and Air Pollution on Soil Properties and Plant Diversity in Northeastern U.S. hardwood forests: Model Setup and Evaluation. Water, Air and Soil Pollution. In review. 2019

Bengtsson. Å. and Sjöberg, S., Surface complexation and proton-promoted dissolution in aqueous apatite systems. Pure Appl. Chem., 81. 1569-1584, 2009.

Berg A. and Banwart, S.A. Carbon dioxide mediated dissolution of Ca-feldspar: implications for silicate weathering. Chemical Geology 163, 25-42. 2000 
Berg, A. and Banwart, A.S., Anorthite surface speciation and weathering reactivity in bicarbonate solutions at $25^{\circ} \mathrm{C}$. Proceedings of the workshop " $\mathrm{CO}_{2}$ Chemistry", Hemavan, Sweden, Sept. 13-16, 1993. Proceedings of the English Royal Society of Chemistry. 1994

Bibi, I., Singh, B., Silvester, E., Dissolution of phyllosilicates under saline acidic conditions. 19 ${ }^{\text {th }}$ World Congress of Soil Science, Soil Solutions for a Changing World, 1 - 6 August 2010, Brisbane, Australia. 4 pages. Published on DVD. 2010

Bickmore, B.R., Nagy, K.L., Gray, A.K., Brinkerhoff, A.R. The effect of $\mathrm{Al}(\mathrm{OH})_{4}^{-}$on the dissolution rate of quartz. Geochimica et Cosmochimica Acta, 70, 290-305. 2006

Binder, T., Vox, A., Belyazid, S., Haraldsson, H., Svensson, M. Developing system dynamics models from causal loop diagrams. 21 pp. https://www.semanticscholar.org/, https://pdfs.semanticscholar.org/cf00/b9084b05ba357bf0c5fa7a5b9cc1b5695015.pdf 2003.

Blake, R.E. and Walter, L.M. Effects of organic acids on the dissolution of orthoclase at $80^{\circ} \mathrm{C}$ and pH 6. Chemical Geology $132,91-$ 102. 1996

Bobbink, R., Draajers, G., Erisman, J.W., Gregor, H.D. (Ed). Henriksen, A., Hornung, M., Iversen, T., Kucera, V., Posch, M., Rihm, B., Spranger, T., Sverdrup, H., de Vries, W., Werner B., (Ed) Manual on methodologies and criteria for mapping critical levels/loads and geographical areas where they are exceeded. Umweltbundesamt Texte 71:96, issn 0722-186X. 1996

Bonten, L.T.C., Reinds, G.J., Groenenberg, J.E., de Vries, W., Posch, M. Evans; C.D. Belyazid, S., Braun S., Moldan, F., Sverdrup, H.U. Kurz, D.. Dynamic geochemical models to assess deposition impacts and target loads of acidity for soils and surface waters. In: W. de Vries, J-P. Hettelingh, M. Posch (Eds) Critical Loads and Dynamic Risk Assessments: Nitrogen, Acidity and Metals in Terrestrial and Aquatic Ecosystems: 225-251. Springer Verlag. 2015

Bortoluzzi, E, Belyazid, S., Alard, D., Corcket, T., Gauquelin, T., Gégout, J.C., Nihlgard, B., Party, J.P., Sverdrup, H., Probst, A. Modélisation dynamique de l'impact des dépôts atmosphériques azotés sur la biodiversité forestière: évaluation des charges critiques. Session 28: Modélisation mécaniste: réponses aux perturbations environnementales, de l'individu à la population. In: (Eds.) Bertrand, J.C., Bonis, A., Caquet, T., Franc, A., Garnier, E., Olivieri, I., Thébaud, C., Roy, J. Proceedings of the Colloque Ecologie 2010 Montpellier 2-4 septembre 2010. A l'initiative des réseaux: AFEM - COMEVOL - ECOVEG - JEF - PPD - REID - SFE - TRAITS. 2010.

Blum A.E. Feldspars in weathering. In Feldspars and their Reactions (ed. I. Parsons). Kluwer Academic, Dordrecht, Boston. 595-630. 1994

Blum A.E. and Lasaga A.C. The role of surface speciation in the dissolution of albite. Geochimica et Cosmochimica Acta 55, 2193 2201. 1991

Blum A.E. and Stillings L.L. Feldspar dissolution kinetics. Reviews in Mineralogy 31, 291-331. 1995

Bossel, H. Earth at the crossroads. Paths to a sustainable future. Cambridge University Press, 387 pages. 1998.

Brady P.V. and Walther J.V. Surface chemistry and silicate dissolution at elevated temperatures. American Journal of Science 292, 639. 1992

Brady, P.V., Carroll, S.A., Direct effect of $\mathrm{CO}_{2}$ and temperature on silicate weathering: possible implications for climate control. Geochimica et Cosmochimica Acta 58, 1853-1856. 1994.

Brady, P.V., Gislason, S.R., Seafloor weathering controls or atmospheric $\mathrm{CO}_{2}$ and global climate. Geochimica et Cosmochimica Acta 61, 965-973. 1997

Bray, A.W., Oelkers, E.H., Bonneville, S., Wolff-Boenisch, D., Potts, N.J., Fones, G., Benning, L.G. The effect of pH, grain size and organic ligands on biotite weathering rates. Geochimica et Cosmochimica Acta 164, 127-145. 2015

Bray, A.W., Benning, L.G., Bonneville, S., Oelkers E.H., Biotite surface chemistry as a function of aqueous fluid composition. Biotite surface chemistry as a function of aqueous fluid composition Geochimica et Cosmochimica Acta 128, 58-70. 2013

Brandt F., Bosbach, D., Krawczyk-Bärsch, R., Arnold, T., Bernhard, G. Chlorite dissolution in the acid pH range: A combined microscopic and macroscopic approach. Geochimica et Cosmochimica Acta, 67: 1451-1461. 10.1016/S00167037(02)01293-O. 2005

Brantley, S. Reaction kinetics of primary rock-forming minerals under ambient conditions. In: Treatise on Geochemistry, Volume 5. Editor: James I. Drever. Executive Editors: Heinrich D. Holland and Karl K. Turekian. ISBN 0-08-043751-6. Elsevier, 73117. 2003

Brantley, S, Chapter 5: Kinetics of mineral dissolution. 151-263. In: Kinetics of water-rock interaction. Edited by Brantley, S.L., Kubicki, J.D., White, A.F., Springer Verlag. ISBN 978-0-387-73562-7. 2008b

Brantley S. L. Kinetics of Water-Rock Interaction. Springer. 2008.

Brantley, S.L., Conrad, C.F. Analysis of Rates of Chemical Reactions, in Kinetics of Water-Rock Interaction, S.L. Brantley, J.D. Kubicki, \& A.F. White (eds.), Springer, New York, Chapter 1, 1-37. 2008

Brantley, S.L. Kinetics of Mineral Dissolution, in: Kinetics of Water-Rock Interaction. S.L. Brantley, J.D. Kubicki, \& A.F. White (eds.), Springer, New York, Chapter 5, 151-210. 2008.

Brantley S.L. and Chen Y. Chapter 4: Chemical weathering rates of pyroxenes and amphiboles. In Chemical Weathering Rates of Silicate Minerals (eds. A.F. White and S.L. Brantley). Mineralogical Society of America, Washington, DC, Reviews in Mineralogy 31, 119-172. 1995

Brantley S.L., and Stillings L., An integrated model for feldspar dissolution under acid conditions. Mineralogical Magazine A 58, $117-118.1994$

Brantley S.L. and Stillings L.L. Feldspar dissolution at $25^{\circ} \mathrm{C}$ and low pH. American Journal of Science 296, 101-127. 1996

Braun, J., Mercier, J., Guillocheau, F., Robin. C., A simple model for regolith formation by chemical weathering. Journal of Geophysical Research: Earth Surface 121: 2140-217. 2016,

Bricker, O., Paces, T., Johnson, C., Sverdrup, H., Weathering and erosion aspects of small catchment research. In: Cerny, J. (Ed.) Biogeochemistry of small catchments, 51:85-106. John Wiley and sons. 1996

Burch, T.E., Nagy, K.L., Lasaga, A.C. Free energy dependence of albite dissolution kinetics at $80^{\circ} \mathrm{C}$ and $\mathrm{pH} 8.8$. Chemical Geology 105:137-162. 1993

Cama J., Ganor J., Ayora C. and Lasaga A.C. Smectite dissolution kinetics at $80^{\circ}$ and $\mathrm{pH}$ 8.8. Geochimica et Cosmochimica Acta $64,2701-2717.2000$

Carroll S.A. and Knauss K.G. Dependence of labradorite dissolution kinetics on $\mathrm{CO}_{2}(\mathrm{aq}), \mathrm{Al}(\mathrm{aq})$ and temperature. Lawrence Livermore National Laboratory. Report from Technical Information Department's Digital Library 
http://www.llnl.gov/tid/Library.html 17 pp. 2001

Carroll S.A. and Knauss K.G. Dependence of labradorite dissolution kinetics on $\mathrm{CO} 2(\mathrm{aq}), \mathrm{Al}(\mathrm{aq})$ and temperature. Chemical Geology 217, 213-225. 2005

Carroll, S.A. and Smith, S. Chlorite Dissolution Kinetics at Variable $\mathrm{pH}$ and Temperatures up to $275^{\circ} \mathrm{C}$. Lawrence Livermore National Laboratory. LLNL-TR-644422. 12 pages. 2013.

Casey W.H., Westrich H.R., Holdren G.R. Dissolution rates of plagioclase at $\mathrm{pH}=2$ and 3. American Mineralogist 76, 211-217. 1991

Casey, W.H. and Sposito, G. On the temperature dependence of mineral dissolution rates. Geochimica et Cosmochimica Acta, 56, 3825-3830. 1992

Casey, W.H., On the relative dissolution rates of some oxides and orthosilicate minerals. J. Colloid Interface Science 146, 586-589. 1991

Casey W.H. and Westrich, H.R. Control of dissolution rates of orthosilicate minerals by divalent metal-oxygen bonds. Nature 355: 157-159. 1992

Casey, W.H., Westrich,,H.R., Arnold, G.W., Surface chemistry of labradorite feldspar reacted with aqueous solutions at pH 2,3, and 12. Geochimica et Cosmochimica Acta 52: 2795-2807. 1988

Casetou-Gustafson, S., Hillier, S., Akselsson, C., Simonsson, M., Stendahl, J., Olsson, B. Comparison of measured (XRPD) and modeled (A2M) soil mineralogies: A study of some Swedish forest soils in the context of weathering rate predictions. Geoderma. 310. 77-88. 2018.

Chaïrat, C., Schott, J., Oelkers, E.H., Lartigue, J-E., Harouiya, N. Kinetics and mechanism of natural fluorapatite dissolution at $25^{\circ} \mathrm{C}$ and $\mathrm{pH}$ from 3 to 12. Geochimica et Cosmochimica Acta 71:5901-5912. 2007

Chen, Y., and Brantley, S.L. Dissolution of forsteritic olivine at $65^{\circ} \mathrm{C}$ and $2<\mathrm{pH}<5$. Chemical Geology $165 ; 267-281.2000$

Chen, Y., and Brantley, S.L. Temperature- and pH-dependence of albite dissolution rate at acid pH. Chemical Geology 135, 275-290. 1997.

Chen, Y., and Brantley, S.L. Diopside and anthophyllite dissolution at $25^{\circ}$ and $90^{\circ} \mathrm{C}$ and acid pH. Chemical Geology 147: 233-248, 1998

Chin, P. K. F. and Mills, G. L.. Kinetics and Mechanisms of Kaolinite Dissolution - Effects of Organic-Ligands. Chemical Geology 90, 307-317. 1991

Critelli, T., Marini, L., Schott, J., Mavromatis, V.M., Apollaro, C., Rinder, T., de Rosa, R., Oelkers, E.H. Dissolution rate of antigorite from a whole-rock experimental study of serpentinite dissolution from $2<\mathrm{pH}<9$ at $25^{\circ} \mathrm{C}$ : Implications for carbon mitigation via enhanced serpentinite weathering. Applied Geochemistry 61: 259-271. 2015

Critelli, T., Marini, L., Schott, J., Mavromatis, V., Apollaro, C., Rinder, T., De Rosa, R., Oelkers, E.H. Dissolution rates of actinolite and chlorite from a whole-rock experimental study of metabasalt dissolution from pH 6-12 at $25^{\circ} \mathrm{C}$. Chemical Geology 390 , $100-108.2014$

Cory, N., Laudon, H., Köhler, S., Seibert, J., Bishop, K. Evolution of soil solution aluminium during transport along a forested boreal hillslope. J. Geophys Res-Biogeo 112(G3). Artn G0301410.1029/2006jg000387. 2007

Cotton, A. Dissolution kinetics of clinoptilolite and heulandite in alkaline conditions. Bioscience Horizons, 1·38-44.2008

Crundwell, F.K., The dissolution and leaching of minerals: Mechanisms, myths and misunderstandings. Hydrometallurgy 139, 132 148. 2013.

Crundwell, F.K., The mechanism of dissolution of minerals in acidic and alkaline solutions: Part I — A new theory of non-oxidation dissolution. Hydrometallurgy 149: 252-264. 2014a.

Crundwell, F.K., The mechanism of dissolution of minerals in acidic and alkaline solutions: Part II — Application to silicates. Hydrometallurgy 149, 265-275. 2014b.

Crundwell, F.K., The mechanism of dissolution of minerals in acidic and alkaline solutions: Part III - Application to oxides and sulfides. Hydrometallurgy 149, 71-81. 2014c.

Crundwell, F.K., The mechanism of dissolution of forsterite, olivine and minerals of the orthosilicate group. Hydrometallurgy 150 : 68-82. 2014d.

Crundwell, F. K. The Mechanism of dissolution of the feldspars: Part I Dissolution at conditions far from equilibrium. Hydrometallurgy 151, 151-162.2015a

Crundwell, F. K. The Mechanism of dissolution of the feldspars: Part II Dissolution at conditions close to equilibrium. Hydrometallurgy 151, 163-171.2015b

Crundwell, F.K., The mechanism of dissolution of minerals in acidic and alkaline solutions: Part VI a molecular viewpoint. Hydrometallurgy 161, 34-44. 2016.

Crundwell, F.K., On the mechanism of the dissolution of quartz and silica in aqueous solutions ACS Omega: 2:1116-1128. 2017

Cubillas, P., Köhler, S., Prieto, M., Chairat, C., Oelkers, E.H. Experimental determination of the dissolution rates of calcite, aragonite, and bivalves. Chemical Geology 216, 59-77. 2016

Dambrinne, E., Sverdrup, H., Warfvinge, P. Atmospheric deposition; Forest management and soil nutrient availability; A modelling exersize. In: Bonneau M. Landmann, G., (Ed.), Forest Decline and Acidification Effects in the French Mountains, 259-269. Springer Verlag, Berlin. 1995

Daval, D., Testemale, D., Recham, N., Tarascon, J.M., Siebert, J., Martinez, I., Guyot, F. Fayalite $\left(\mathrm{Fe}_{2} \mathrm{SiO}_{4}\right)$ dissolution kinetics determined by X-ray absorption spectroscopy. Chemical Geology 275, 161-175. 2010a

Daval., D., Hellmann, R., Corvisier, J., Tisserand, D., Martinez, I., Guyot, F. Dissolution kinetics of diopside as a function of solution saturation state: Macroscopic measurements and implications for modeling of geological storage of $\mathrm{CO}_{2}$ Geochimica et Cosmochimica Acta 74: 2615-2633. 2010b

Daval, D., Hellmann, R., Marinez, I., Gangloff, S., Guyot, F. Lizardite serpentine dissolution kinetics as a function of $\mathrm{pH}$ and temperature, including effects of elevated $\mathrm{pCO}_{2}$. Chemical Geology 351: 245-256. 2013

Declercq, J., Bosc, O., Oelkers E.H., Do organic ligands affect forsterite dissolution rates? Applied Geochemistry 39, 69-77. 2013

Declercq, J., Diedrich, T., Perrot, M., Gislason, S.R., Oelkers, E.H., . Experimental determination of rhyolitic glass dissolution rates at $40-200^{\circ} \mathrm{C}$ and $2<\mathrm{pH}<10.1$ Geochimica et Cosmochimica Acta 100, 251-263 2013.

1212 Denbigh, K., The Principles of Chemical Equilibrium, Cambridge University Press, Cambridge (U.K.). 1971 
Devidal J.-L., Schott J., Dandurand J.-L. An experimental study of kaolinite dissolution and precipitation kinetics as a function of chemical affinity and solution composition at $150^{\circ} \mathrm{C}, 40$ bars, and $\mathrm{pH} 2,6.8$, and 7.8. Geochimica et Cosmochimica Acta 61: 5165-5186. 1997

Diedrich, T., Schott, J., Oelkers, E.H. An experimental study of tremolite dissolution rates as a function of $\mathrm{pH}$ and temperature: implications for tremolite toxicity and its use in carbon storage. Mineralogical Magazine 78: 1449-1464. 2014

Dixit S. and Carroll S.A. Effect of solution saturation state and temperature on diopside dissolution. Geochemical Transactions 8 . 2007

Dixon J.L, and von Blanckenburg, F., Soils as pacemakers and limiters of global silicate weathering. Comptes Rendus Geoscience, 344:597-609. 2012

Dresel P.E. The dissolution kinetics of siderite and its effect on acid mine drainage. Ph.D. thesis. Pennsylvania State University. 1989 Drewer, J., Murphy, K.M., Clow, D.W. Field weathering rates versus laboratory dissolution rates: an update. Goldschmidt conference Edinburgh 1994. 239-240. 1994

Drever J..I., Poulson S.R., Stillings L.L., Sun Y. The effect of oxalate on the dissolution rate of quartz and plagioclase feldspars at 20$25^{\circ} \mathrm{C}$. Geochemistry of Crustal Fluids: Water/Rock Interaction during Natural Processes, 39. 1996

Drever, J.I. and Clow, D.W. Weathering rates in catchments. In A. F. White and S. L. Brantley, (Eds), Chemical weathering rates of silicate minerals. Mineralogical Society of America, Washington D. C. Reviews in mineralogy 31:463-483. 1995

Drever, J.I, and Zobrist, J., Chemical weathering of silicate rocks as a function of elevation in the southern Swiss Alps. Geochimica et Cosmochimica Acta, 56:3209-3216. 1992

Drever, J., and Stillings, L. The role of organic acids in mineral weathering, Colloids Surf. A, 120: 167-181. 1997,

Drever, J.I., The Geochemistry of Natural Waters , Prentice Hall, Englewood Cliffs, N.J. 1988

Drever, J.I., The effect of land plants on weathering rates of silicate minerals, Geochimica et Cosmochimica Acta 58, 2325-2332. 1994

Dorozhkin, S. Dissolution mechanism of calcium apatite in acids: A review of literature. World Journal of methodology 26:1-17. 2012

Dove, P.M., and Crerar, D.A. Kinetics of quartz dissolution in electrolyte solutions using a hydrothermal mixed flow reactor. Geochim et Cosmochim Acta, 54:955-969. 1990.

Duan, L., Hao, J., Xie, S., Zhou, Z., Xuemei Ye. Determining weathering rates of soils in China. Geoderma 110, 205-225. 2002

Duckworth, O.W., and Martin, S.T. Role of molecular oxygen in the dissolution of siderite and rhodochrosite. Geochimica et Cosmochimica Acta, 68, 607-621. 2003

Duckworth, O.W. and Martin, S.T. Connections between surface complexation and geometric models of mineral dissolution investigated for rhodochrosite. Geochim. Cosmochim. Acta 67, 1787-1801. 2003

Erlandson, M., Oelkers, E.H., Bishop, K., Sverdrup, H.U., Belyazid, S., Ledesma, J.L.J., Köhler, S.J.,, Spatial and temporal variations of base cation release from chemical weathering on a hillslope scale Chemical Geology 441, 21:1-13. 2016

Erlandson, M., Sverdrup, H.U., M., Bishop, K., Belyazid, S., Ameli, A., Köhler, S.J., Catchment export of base cations: Improved mineral dissolution kinetics influence the role of water transit time (This issue) Soil 1-19. 2019.

Fernandez-Bastero, S., Gil-Lozano, C., Briones, M.J.I., Gago-Duport, L. Kinetic and structural constraints during glauconite dissolution: implications for mineral disposal of $\mathrm{CO}_{2}$ Mineralogical Magazine 72, 27-31. 2008

Fischer, S., and Liebscher, E., Dissolution Kinetics of Iron Carbonate, Illite and Labradorite - $\mathrm{CO}_{2}$-Saline Fluid- mineral Experiments within the GaMin'11 Inter-laboratory Comparison Exercise. - Energy Procedia, 63, 5461-5466. A. 2014

Finlay, R., Wallander, H., Smits, M.M., Holmström, S., van Hees, P., Lian, B., Rosling, A. The role of fungi in biogenic weathering in boreal forest soils. Fungal Biology Review 23: 101-106. 2010

Flaathen, K., Gislason, S.R., Oelkers, E.H. The effect of aqueous sulphate on basaltic glass dissolution rates. Chemical Geology 277, 345-354. 2010

Forrester, J. W. Industrial Dynamics. Pegasus Communications. ISBN 1-883823-36-6. 1961.

Forrester, J. W. Urban Dynamics. Pegasus Communications. ISBN 1-883823-39-0. 1969.

Forrester, J., World dynamics. Pegasus Communications, Waltham MA. 1971.

Forsius, M., Alveteg, M., Jenkins, A., Johansson, M., Kleemola, S., Lükewille, A., Posch, M. Sverdrup. H. MAGIC, SAFE and SMART model application at integrated monitoring sites: Effects of emission reduction scenarios. Water, Air and Soil Pollution 195:2-30. 1998.

Fouda, M.F.R., Amin, R.E.-S., Abd-Elzaher, M.M. Extraction of magnesia from Egyptian serpentine ore via reaction with different acids. I. Reaction with sulfuric acid. Bull. Chem. Soc. Jpn, 1907-1912. 1996a.

Fouda, M.F.R., Amin, R.E.-S., Abd-Elzaher, M.M. Extraction of magnesia from Egyptian serpentine ore via reaction with differ- ent acids. II. Reaction with nitric and acetic acids. Bull. Chem. Soc. Jpn. 69, 1913-1916. 1996b.

Frogner, P and Schweda, P. Hornblende dissolution kinetics at $25^{\circ} \mathrm{C}$. Chemical Geology 151, 169-179. 1998.

Fu, Q., Lu, P., Konishi, H., Dilmore, R., Xu, H., Seyfried, W.E. Jr, Zhu, C. Coupled alkali feldspar dissolution and secondary mineral precipitation in batch systems: 1 . New experiments at $200^{\circ} \mathrm{C}$ and 300 bars Chemical Geology 258, 125-135 2009

Fumuto, T., Shindo, J., Oura, N., Sverdrup, H. Adapting the PROFILE model to calculate the critical loads for East Asian soils by including volcanic glass weathering and alternative aluminium solubility system. Water, Air and Soil Pollution 130:12471252. 2001

Gahrke, T., Pina P.S., Cornell, R.M., Dissolution kinetics of montmorillonite in hydrochloric and oxalic acid. Journal of the American Society 114, $102-112.2005$.

Galeczka, I., Wolff-Boenisch, D., Oelkers, E.H., Gislason, S.R., An experimental study of basaltic glass- $\mathrm{H}_{2} \mathrm{O}-\mathrm{CO}_{2}$ interaction at 22 and $50^{\circ} \mathrm{C}$ : implications for subsurface storage of $\mathrm{CO}_{2}$. Geochimica et Cosmochimica Acta 126, 123-145. 2014

Ganor, J., Roueff, E., Erel, Y., Blum, J. The dissolution kinetics of a granite and its minerals - implications for comparison between laboratory and field dissolution rates. Geochimica et Cosmochimica Acta 69, 2043-2056. 2005

Ganor, J., Lu, P., Zheng, Z., Zhu, C. Bridging the gap between laboratory measurements and field estimations of weathering using simple calculations. Environ Geol 53:599-610. 2007

Gainey, S.R., Hausrath, E.M., Hurowitz, J.A., Milliken, R.E., Nontronite dissolution rates and implications for Mars. Geochimica et Cosmochimica Acta 126: 192-211 2014. 
Gautier, J. M., Oelkers, E. and Schott, J., Experimental study of K-feldspar dissolution rate as a function of chemical affinity at $150^{\circ} \mathrm{C}$ and $\mathrm{pH}$ 9, Geochimica et Cosmochimica Acta 58, 4549-4560. 1994

Gaudio, N., Belyazid, S., Gendre, X., Mansat, A., Nicolas, M., Rizzetto, S., Sverdrup, H., Probst, A. Combined effect of atmospheric nitrogen deposition and climate change on temperate forest soil biogeochemistry: a modeling approach. Ecological Modelling 30. 624-634. 2015.

Gautelier, M., Oelkers, E.H., Schott, J., An experimental study of dolomite dissolution rates as a function of pH from 0.5 to 5 and temperature from 25 to $80^{\circ} \mathrm{C}$. Chemical Geology $157,13-26,1999$

Gislason S.R. and Hans P.E. Meteoric water-basalt interactions. I: A laboratory study. Geochimica et Cosmochimica Acta 51, 28272840. 1987

Gislason, S.R., Oelkers, E.H. Mechanism, rates, and consequences of basaltic glass dissolution: II. An experimental study of the dissolution rates of basaltic glass as a function of $\mathrm{pH}$ and temperature. Geochimica et Cosmochimica Acta 67, 3817-3832. 2003

Gislason, S.R., Arnorsson, S., Armannsson, H., Chemical weathering of basalt in southwest Iceland: effects of runoff, age of rocks and vegetative/glacial cover. American Journal of Science 296, 837 - 907. 1996.

Glover, E., Faanu, A., Fianko, J.R. Dissolution Kinetics of Stilbite at Various Temperatures under Alkaline Conditions. West African Journal of Applied Ecology, 16: 95-105. 2010

Godderis, Y., Francois, L.M., Probst, A., Schott, J., Moncoulon, D., Labat, D., Viville, Didier. Modelling weathering processes at the catchment scale: The WITCH numerical model. Geochimica et Cosmochimica Acta, 70, 1128-1147. 2006

Golubev, S.V., Pokrovsky, O.S., Schott, J. Laboratory weathering of Ca- and Mg-bearing silicates: weak effect of $\mathrm{CO}_{2}$ and organic ligands. Geochimica et Cosmochimica Acta, A418. 2004.

Golubev S. V., Pokrovsky O. S. and Schott J. 2005 Experimental determination of the effect of dissolved $\mathrm{CO}_{2}$ on the dissolution kinetics of $\mathrm{Mg}$ and Ca silicates at $25^{\circ} \mathrm{C}$. Chemical Geology 217, 227-238.

Guidry M.W. and Mackenzie F.T. Experimental study of igneous and sedimentary apatite dissolution: control of pH, distance from equilibrium, and temperature on dissolution rates. Geochimica et Cosmochimica Acta 67, 2949-2963. 2003

Goyne, K.W., Brantley, S.L., Chorover, J. Effects of organic acids and dissolved oxygen on apatite and chalcopyrite dissolution: Implications for using elements as organomarkers and oxymarkers. Chemical Geology 234:28-45. 2006

Gudbrandsson, S., Wolff-Boenisch, D., Gislason, S.R., Oelkers, E.H. An experimental study of crystalline basalt dissolution from $2<\mathrm{pH}<11$ and temperatures from 5 to $75^{\circ} \mathrm{C}$. Geochimica et Cosmochimica Acta 75, 5496-5509. 2011

Gudbrandsson, S., Wolff-Boenisch, D., Gislason, S.R., Oelkers, E.H. Experimental determination of plagioclase dissolution rates as a function of its composition and $\mathrm{pH}$ at $22^{\circ} \mathrm{C}$. Geochimica et Cosmochimica Acta 139:154-172. 2014

Guidry, M.W., and Mackemzie, F.T. Experimental Study of Igneous and Sedimentary Apatite Dissolution: Control of pH, Distance from Equilibrium, and Temperature on Dissolution Rates.. Geochimica et Cosmochimica Acta, 67, 2949-2963. 2003

Gustafsson A.B., Puigdomenech. I.. The effect of $\mathrm{pH}$ on chlorite dissolution rates at $25^{\circ} \mathrm{C}$. Materials Res Soc Symp Proc, 757:649655. 2003

Hamilton J.P., Pantano C.G., Brantley S.L. Dissolution of albite glass and crystal. Geochimica et Cosmochimica Acta 64, 26032615. 2000

Hamilton, J.P., Brantley, S.L., Pantano, C.G., Criscenti, L.J., Kubicki, J.D., Dissolution of nepheline, jadeite, and albite glasses: towards better models for aluminosilicate dissolution. Geochimica et Cosmochimica Acta 65, 3683-3702. 2001.

Hangx, S.J. and Spiers, C.J. Reaction of plagioclase feldspars with $\mathrm{CO}_{2}$ under hydrothermal conditions. Chemical Geololgy 265, 8898. 2009

Hansley, P.L., and Briggs, P.H., Garnet Dissolution in Oxalic Acid-A Possible Analog for Natural Etching of Garnet by Dissolved Organic Matter. U.S. Geological Survey Bulletin 2106. United States Government Printing Office, Washington: 1994

Haraldsson, H., Sverdrup, H., Belyazid, S., Sigurdsson, B., Halldorsson, G. Assessment of effects of afforestation on soil properties in Iceland, using systems analysis and system dynamics methods. Icelandic Agricultural Science 20:107-123. 2007

Haraldsson, H. 2004 Introduction to systems thinking and causal loop diagrams. Reports in Ecology and Environmental Engineering 1:2004, 5th edition. Lund University, Lund, Sweden.

Haraldsson H. and Sverdrup, H., 2005, On aspects of systems analysis and dynamics workflow. Proceedings of the systems dynamics society, July 17-21, 2005 International Conference on systems dynamics, Boston, USA. 1-10 pages. http://www.systemdynamics.org/conferences/2005/proceed/papers/HARAL310.pdf

Harouiya, N., Chaïrat, C, Köhler, S.J., Gout, R, Oelkers, E.H. The dissolution kinetics and apparent solubility of natural apatite in closed reactors at temperatures from 5 to $50^{\circ} \mathrm{C}$ and $\mathrm{pH}$ from 1 to 6. Chemical Geology 244: 554-568. 2007

Harouiya, N. and Oelkers, E.H. An experimental study of the effect of aqueous fluoride on quartz and alkali-feldspar dissolution rates. Chemical Geology 205, 155-167. 2004

Haug, T.A., Kleiv, R.A., Munz, I.A., Investigating dissolution of mechanically activated olivine for carbonation purposes. Applied Geochemistry 25, 1547-1563. 2010

Hausrath, E.M., A. Neaman, S.L. Brantley. Elemental release rates from dissolving basalt and granite with and without organic ligands. American Journal of Science 309, 633-660. 2009.

Hayashi, H., and Yamada, M. Kinetics of dissolution of non-crystalline oxides and crystalline clay minerals in a basic ion solution. Clay and Clay Minerals 38:308-3114. 1990

van der Heijden, G., Belyazid, S. LU ; Dambrine, E.; Ranger, Jacques and Legout, A. NutsFor a process-oriented model to simulate nutrient and isotope tracer cycling in forest ecosystems Environmental Modelling and Software 9:365-380. 2017

Helgeson, H., Murphy, W., Aagaard, P.: Thermodynamics and kinetic constraints on reaction rates among minerals and aqueous solutions: II. Rate constants, effective surface area and the hydrolysis of feldspar. Geochimica et Cosmochimica Acta 48, 2405-2432. 1984

Hellmann, R., Daval, D., Tisserand, D., Renard, F. Albite feldspar dissolution kinetics as a function of the Gibbs free energy at high $\mathrm{pCO}_{2}$, In Water Rock Interaction (Bullen, T.D., Wang, Y., eds.), Taylor \& Francis, London, 591-595. 2007

Hellmann, R. and Tisserand, D. Dissolution kinetics as a function of the Gibbs free energy of reaction: An experimental study based on albite feldspar. Geochimica et Cosmochimica Acta 70: 364-383. 2006

Hellmann, R., Daval, D., Tisserand, D. The dependence of albite feldspar dissolution kinetics on fluid saturation state at acid and basic pH: Progress towards a universal relation. Geoscience 342: 676-684. 2010 
Hettelingh, J.P., Posch, M., de Vries, W., Bull, K., Sverdrup, H. Guidelines for the computation and mapping of nitrogen critical loads and exceedance in Europe. In: Grennfelt, P-I. and Lövblad, G. (Eds) Critical Loads for Nitrogen - A workshop report: 287303. Nordic Council of Ministers. 1992

Hettelingh, J.P., Chadwick, M., Sverdrup, H., Zhou, D. Assessment of environmental effects of acid deposition. In; RAINS-ASIA; An assessment model for air pollution in Asia. W. Foell, M. Ammann, G. Carmichael, M. Chadwick, J. P. Hettelingh, L. Hordijk, D. Zhou (eds). Chapter V:1-59, World Bank. 1995

Hettelingh, JP, Sverdrup, H, Zhao, D. Deriving critical loads for Asia. Water, Air and Soil Pollution 85:2565-2570. 1996

Hettelingh, J.P., Sverdrup, H., Zhao, D. Assessment of environmental effects of acidic deposition in Asia. Water, Air, and Soil Pollution 85:1-24. 1996.

Hilley, G.E., Chamberlain, C.P., Moon, S., Porder, S., Willet, S.D., Competition between erosion and reaction kinetics in controlling silicate-weathering rates. Earth and Planetary Science Letters 293: 191-199. 2010.

Holmqvist, J., Ögaard, A., Öborn, I., Edwards, T., Mattson, L., Sverdrup, H. Estimating potassium release from weathering in Northern European agricultural systems using PROFILE and long term experiments European Journal of Agronomy 20:149-163. 2003

Holmqvist, J., Thelin, G., Rosengren U., Stjernquist, I., Svensson, M., Wallman, P., Sverdrup, H. Assessing sustainability in the Asa research park In: Developing principles for sustainable forestry Results from a research program in southern Sweden. Sverdrup, H., and Stjernquist, I., (Eds.) Managing Forest Ecosystems 5:381-426. Kluwer Academic Publishers, Amsterdam. 2002

Holmqvist, J. and Sverdrup, H. Vittringskartor ger uthälligare skogsbruk. Skog och Forskning 4/2001;25-27. 2001

Holmqvist, J., Sverdrup, H., Petersson, P., Örlander G. Vittringens betydelse för uthållig produsjon. In: Olsson, K. (Ed.). Sustainable Forestry in Southern Sweden, Årsrapport 1999; Tema Skogsmarkens långsiktiga produksjonsförmåga 18-21. 1999

Hodson, M.E. Does reactive surface area depend on grain size? Results from $\mathrm{pH} 3,25{ }^{\circ} \mathrm{C}$ far-from-equilibrium flow-through experiments on anorthite and biotite. Geochimica et Cosmochimica Acta 70, 1655-1667. 2006a

Hodson M. Searching for the perfect surface area normalizing term - a comparison of BET surface area-, geometric surface area-and mass-normalized dissolution rates of anorthite and biotite. J. Geochem. Explor. 88, 288-291. 2006b

Hodson M.E. The influence of Fe-rich coatings on the dissolution of anorthite at pH 2.6. Geochimica et Cosmochimica Acta 67, 3355-3363. 2003

Hodson, M. and Langan, S.J. Considerations of uncertainty in setting critical loads of acidity of soils: the role of weathering rate determination. Environmental Pollution 106: 73-81. 1999b

Hodson, M.E., Langan, S.J., Wilson, M.J.A sensitivity analysis of the PROFILE model in relation to the calculation of soil weathering rates. Applied Geochemistry 11: 835-844. 1996.

Hodson, M.E., Langan, S.J. and Wilson, M.J.A critical evaluation of the use of the PROFILE model in calculating mineral weathering rates. Water Air and Soil Pollution 98: 79-104. 1997

Houle, D., Lamoureux, P., Belanger, N., Bouchard, M., Gagnon, C., Couture, S., Bouffard, A., Soil weathering rates in 21 catchments of the Canadian Shield. Hydrol. Earth Syst. Sci., 16, 685-697. 2012.

Hänchen, M., Prigiobbe V., Storti G., Seward T.M., Mazzotti M. Dissolution kinetics of forsteritic olivine at $90-150^{\circ} \mathrm{C}$. Geochimica et Cosmochimica Acta 70, 4403-4416. 2006

Huertas, F.J., Caballero, E., de Cisneros, C.J., Huertas, F., Linares, J. Kinetics of montmorillonite dissolution in granitic solutions. Applied Geochemistry 16, 397-407. 2001

Huertas, F.J., Chou, L., Wollast, R. Mechanism of kaolinite dissolution at room temperature and pressure. Part II: kinetic study. Geochimica et Cosmochimica Acta 63, 3261-3275. 1999

Hultberg, H., Hultengren, S., Grennfelt, P., Oskarsson, H., Kalén, C., Pleijel, H.: Air pollution, environment and future. 30 years of research on forest, soils and water. Gårdsjöstiftelsen and Naturcentrum AB. 60pp. 2007.

Jin, L., Andrews, D.M., Holmes, G.H., Lin, H., Brantley, S.L. Opening the "black box": water chemistry reveals hydrological controls on weathering in the Susquehanna Shale Hills Critical Zone Observatory. Vadose Zone Journal 10:928-942. 2011

Johnson, N.C., Thomas, B., Maher, K., Rosenbauer, R.J., Bird, D., Brown, J., Olivine dissolution and carbonation under conditions relevant for in situ carbon storage. Chemical Geololgy 373, 93-105. 2014.

Johnsson, P.A., Blum, A.E., Hochella, M.F.Jr., Parks, G.A., Sposito, G. Direct observation of muscovite basal-plane dis- solution and secondary-phase formation: An XPS, LEED, and SFM study. In Water-Rock International VII (eds. G. Arehardt and R. Hulston),. 159-162. Balkema. 1992

Jönsson, C., Warfvinge, P., Sverdrup, H. Uncertainty in prediction of weathering rate and environmental stress factors with the PROFILE model. Water, Air and Soil Pollution, 81:1-23. 1995

Jönsson, C., Warfvinge, P., Sverdrup, H. The SAFE model applied to the Solling data set. Ecological Modelling, 83:85-96, 1995

Jonckbloedt, R.C.L., Olivine dissolution in sulphuric acid at elevated temperatures-implications for the olivine process, an alternative waste acid neutralizing process. Journal of Geochemical Exploration 62, 337-346. 1998.

Kalinowski, B.E., Dissolution Kinetics and Alteration Products of Micas and Epidote in Acidic Solutions at Room Temperature, PhD Thesis. Stockholm University, Stockholm, 1997

Kalinowski, B., Faith-Ell, C., Schweda, P. Dissolution kinetics and alteration of epidote in acidic solutions at $25^{\circ} \mathrm{C}$. Chemical Geololgy. 151, 181-197. 1998

Kalinowski, B.E. and Schweda, P. Kinetics of muscovite, phlogopite, and biotite dissolution and alteration at pH 1-4, room temperature. Geochimica et Cosmochimica Acta, 60, 367-385. 1995

Kegan, R., Laskow-Lahey, L., The real reason people won’t change. Harvard Business Review - OnPoint 103-111. Originally published in Harvard Business review November 2001. 2014.

Kim, D.H., Toolbox: Guidelines for Drawing Causal Loop Diagrams, The Systems Thinker, 3; 5-6. 1992.

Knauss, K. G., Nguyen S. N., Weed H. C. Diopside dissolution kinetics as a function of $\mathrm{pH}, \mathrm{CO}_{2}$, temperature, and time. Geochimica et Cosmochimica Acta 57, 285-294. 1993

Knutson, G., Bergström, S., Danielsson, L., Jacks, G., Lundin, L., Maxe, L., Sanden, P., Sverdrup, H., Warfvinge, P. Acidification of groundwater in forested till areas. Ecological Bulletins, 44:271-300. 1995

Kolka, R.K.; Grigal, D.F.; Nater, E.A. Forest soil mineral weathering rates: use of multiple approaches. Geoderma 73: 1-21. 1996

Köhler, S.J., Bosbach, D., Oelkers E.H. Do clay mineral dissolution rates reach steady state? Geochimica et Cosmochimica Acta 69 , 1997-2006. 2005 
Köhler, S.J., Dufaud, F., Oelkers E.H. An experimental study of illite dissolution kinetics as a function of pH from 1.4 to 12.2 and temperature from 5 to $50^{\circ} \mathrm{C}$. Geochimica et Cosmochimica Acta 67: 3583-3594. 2003

Kurz, D., Rihm, B., Sverdrup, H., Warfvinge, P. Critical loads of acidity for forest soils: Regionalized PROFILE model. Environmental documentation no. 88. 1-117, Swiss Agency for the Environment, Forest and Landscape, Swiss Government, Bern. 1998a

Kurz, D., Alveteg, M., Sverdrup, H. Acidification of Swiss forest soils; Development of a regional dynamic assessment: Regionalized PROFILE model. Environmental documentation no. 89. 1-115 Swiss Agency for the Environment, Forest and Landscape, Swiss Government, Bern. 1998b

Kurz, D., Rihm, B., Alveteg, M., Sverdrup, H. Steady-state and dynamic assessment of forest soil acidification in Switzerland. Water, Air and Soil Pollution 130: 1217-1222. 2001

Kuwahara, Y., In situ observations of muscovite dissolution under alkaline conditions at $25-50^{\circ} \mathrm{C}$ by $\mathrm{AFM}$ with an air/fluid heater system American Mineralogist, 93: 1028-1033, 2008

Kuwahara, Y., In-situ, real time AFM study of smectite dissolution under high $\mathrm{pH}$ conditions at $25-50^{\circ} \mathrm{C}$. Clay science, 12 , supplement 2, 57-62. 2006a

Kuwahara, Y., In-situ AFM study of smectite dissolution under alkaline conditions at room temperature. American Mineralogist, 91 1142-1149. 2006b

Labat, D. and Viville, D. Modelling weathering processes at the catchment scale: the WITCH numerical model. Geochimica et Cosmochimica Acta 70, 1128-1147. 2006

Lagache, M. Contribution à l'étude de l'altération des feldspaths, dans l'eau, entre 100 et $200^{\circ} \mathrm{C}$, sous diverses pressions de $\mathrm{CO} 2$, et application à la synthèse des minéraux argileux. Bull. Soc. franç. Minér. Crist. 88: 223- 253. 1965

Lagache, M.: New data on the kinetics of the dissolution of the alkali feldspar at $200^{\circ} \mathrm{C}$ in $\mathrm{CO}_{2}$ charged water, Geochimica et Cosmochimica Acta 40, 157-161. 1976,

Lammers, K., Smith, M.M., Carrol, S.A., Muscovite dissolution kinetics as a function of pH at elevated temperature. Chemical Geology 466: 149-158. 2017.

Langan, S.L., Reynolds, B.,, Bain, D.C. The calculation of base cation release from mineral weathering in soils derived from Palaeozic greywackes and shales in upland UK. Geoderma 69, 275-285. 1996a.

Langan, S.L., Sverdrup, H., Cull, M. Calculation of base cation release from the chemical weathering of Scottish soils using the PROFILE model. Water, Air and Soil Pollution 85:2487-2502. 1996b.

Lartigue, J.E. Contribution a l'e'tude de l'alte' ration des silicates. Approche experimentale en milieu ouvert de la cinetique de dissolution a $25^{\circ} \mathrm{C}$ d'un pyroxe 'ne $(\mathrm{Ca}-\mathrm{Mg}-\mathrm{Fe})$ en fonction du $\mathrm{pH}$. These. Universite' de droit, d'e' conomie et des sciences d'Aix-Marseille. 1994

Lasaga, A.C. Fundamental approaches in describing mineral dissolution and precipitation rates. In: White, A.F., Brantley, S.L. (Eds.), Chemical Weathering Rates of Silicate Minerals, 31. Mineralogical Society of America, Washington, D.C., USA. Reviews in Mineralogy 31: 23-86. 1995

Lasaga, A.C. Kinetic Theory in the Earth Sciences. Princeton University Press, Princeton, USA, 811pp. 1998

Lazaro, A, Benac-Vegas, Brouwers, H.J.H., Geus, J.W., Bastida, J. The kinetics of the olivine dissolution under the extreme conditions of nano-silica production. Applied Geochemistry 52:1-15. 2015

Laudon, H., Taberman, I., Ågren, A., Futter, M., Ottosson-Löfvenius M., Bishop, K. The Krycklan Catchment Study-A flagship infrastructure for hydrology, biogeochemistry, and climate research in the boreal landscape. Water Resoures Research 49 , 7154-7158. 2013

Leith, F.I., Dinsmore, K.J., Wallin, M.B., Billett, M.F., Heal, K.V,. Laudon, H., Öquist, M.G., Bishop, K. Carbon dioxide transport across the hillslope-riparian-stream continuum in a boreal headwater catchment. Biogeosciences 12, 1881-1892. 2015.

Lowson, R.T., Comarmond M.C.J., Rajaratnam G., Brown P.L. The kinetics of the dissolution of chlorite as a function of pH and at $25^{\circ}$ C. Geochimica et Cosmochimica Acta 69, 1687-1699. 2005

Lowson, R.T, Brown, P.L., Comamond, M.C.J, Rajataratnam, G. The kinetics of chlorite dissolution. Geochimica et Cosmochimica Acta 71: 1431-1447. 2007

Lu, P., Fu, Q., Seyfried, W.E. Jr, Hedges, S.W., Soong, Y., Jones, K., Zhu, C. Coupled alkali feldspar dissolution and secondary mineral precipitation in batch systems: 2. New experiments with supercritical $\mathrm{CO} 2$ and implications for carbon sequestration. Applied Geochemistry 30:75-90 2013

Lu, P., Konishi, H., Oelkers, E., Zhu, C. Coupled alkali feldspar dissolution and secondary mineral precipitation in batch systems: 5. Results of K-feldspar hydrolysis experiments Chinese Journal of Geochemistry 34:1-12. 2015

Ludwig, C., Casey, W.H., Rock, P.A., Prediction of ligand-promoted dissolution rates from the reactivities of aqueous complexes. Nature 375, 44-46. 1995.

Lüttge, A., Bolton, E.W., Lasaga, A.C. An interferometric study of the dissolution kinetics of anorthite: the role of reactive surface area. American Journal of Science 299, 652-678. 1999

Lång, L.O., Mineral Weathering Rates and Primary Mineral Depletion in Forest Soils, SW Sweden. In: Effects of Acid Deposition and Tropospheric Ozone on Forest Ecosystems in Sweden Ecological Bulletins 44: 100-113. 1995

Maher, K. The dependence of chemical weathering rates on fluid residence time. Earth and Planetary Science Letters. 294:101110. 2010

Malek, S., Martinsson, L., Sverdrup, H. Modelling future soil chemistry at a highly polluted forest site at Istebna in Southern Poland, using the SAFE model. Environmental Pollution 137:568-573. 2005,

Malek, S., Belyazid, S., Sverdrup, H. Modelling changes in forest soil chemistry in the oldest spruce stands in the Potok Dupnianski catchment in Southern Poland using the ForSAFE model. Folia Forestalia Polonica, Series A, 54:209-214. 2012

Malmström, M. and Banwart, S. Biotite dissolution at $25^{\circ} \mathrm{C}$ : The $\mathrm{pH}$ dependence of dissolution rate and stoichiometry. Geochimica et Cosmochimica Acta, 61, 2779-2799, 1997

Malmström, M., Banwart, S., Lewenhagen, J., Duro, L., Bruno, J. The dissolution of biotite and chlorite at $25^{\circ} \mathrm{C}$ in the near-neutral pH region. Journal of Contaminant Hydrology 21: 201-213. 1996

Martinsson, L., Alveteg, M., Kronnäs, V., Sverdrup, H., Westling, O., Warfvinge, P. A regional perspective on present and future soil chemistry at 16 Swedish forest sites. Water, Air, and Soil Pollution 162: 89-105, 2005.

Mast, M.A., and Drever, J.L., The effect of oxalate on the dissolution rates of oligoclase and tremolite: Geochimica et Cosmochimica 
Acta, 51, 2559-2568. 1987,

Maurice, P.A., Mcknight, D.M., Leff, L., Fulghum, J.E., Michael Gooseff, M.. Direct observations of aluminosilicate weathering in the hyporheic zone of an Antarctic Dry Valley stream. Geochimica et Cosmochimica Acta, 66, 1335-1347, 2002

Mazer, J.J. and Walther, J.V. Dissolution kinetics of silica glass as a function of $\mathrm{pH}$ between 40 and $85^{\circ} \mathrm{C}$. Journal of Non-crystallic Solids 170:32-45. 1994

McCourt, G.H. and Hendershot, W.H. 1992. A new method for determining mineral weathering rates in soils. Commun. Soil Sci. Plant Anal. 23: 939-952.

McDonnell T.C., Belyazid S., Sullivan, T.J., Bell, M., Clark, C., Blett, T., Evans, T., Cass, W., Hyduke, A. Sverdrup, H., Vegetation dynamics associated with changes in atmospheric nitrogen deposition and climate in hardwood forests of Shenandoah and Great Smoky Mountains National Parks, USA. Environmental Pollution 237: 662-674. 2018.

McDonnell T.C., S. Belyazid, T.J. Sullivan, H. Sverdrup, W.D. Bowman, E.M. Porter. Modeled subalpine plant community response to climate change and atmospheric nitrogen deposition in Rocky Mountain National Park, USA. Environmental Pollution 187:55-64. 2014

Meadows, D.L., Meadows, D.H., Eds.; Business and Economics: Geneva, Switzerland. 1973

Meadows, D.H., Meadows, D.L., Randers, J., Behrens, W. Limits to growth. Universe Books, New York 1972

Meadows, D.L., Behrens III, W.W., Meadows, D.H., Naill, R.F., Randers, J., Zahn, E.K.O.. Dynamics of Growth in a Finite World. Massachusetts: Wright-Allen Press, Inc. 1974

Meadows, D.H., Meadows, D.L., Randers, J. Beyond the limits: Confronting global collapse, envisioning a sustainable future. Chelsea Green Publishing Company: 1992

Meadows, D. H., Randers, J., Meadows, D. Limits to growth. The 30 year update. Universe Press, New York. 2005

Melegy, A., and Paces, T., Calculating Geochemical Weathering Rates Of Three Different Catchments In The Czech Republic. International Journal of Innovations in Engineering and Technology (IJIET) ISSN: 2319-1058. 2017.

Metz, V., Raanan, H., Pieper, H., Bosbach, D., Ganor, J. Towards the establishment of a reliable proxy for the reactive surface area of smectite. Geochimica et Cosmochimica Acta 69, 2581-2591. 2005

Meyer, N.A. An investigation into the dissolution of pyroxene: A precursor to mineral carbonation of PGM tailings in South Africa. A thesis submitted for the degree of MSc in Engineering in Chemical Engineering at the University of Cape Town, South Africa. 2014

Modin-Edman, A.K., Öborn, I., Sverdrup, H. FARMFLOW-A Dynamic Model for Phosphorus Mass Flow, Simulating Conventional and Organic Management of a Swedish Dairy Farm Agricultural Systems. Agricultural systems 94:431-444. 2007

Mongeon, A., Aherne, J., Watmough, S. Weathering rates and steady-state critical loads for forest soils in the Georgia Basin. Proceedings. 9 pages. http://depts.washington.edu/uwconf/2007psgb/2007proceedings/papers/11d monge.pdf 2007

Montagnac, P., Kohler, S.J., Dufaud,F., Oelkers, E.H., An experimental study of the, dissolution stoichiometry and rates of a natural monazite as a function of temperature from 5 to 50 degrees $\mathrm{C}$ and $\mathrm{pH}$ from 1 to 12.3. Geochimica Et Cosmochimica Acta 66 (15A), A311-A311. 2002

Mulders, J.J.P.A., Harrison,A.L., Christ, J., Oelkers, E.H. Non-stoichiometric dissolution of sepiolite, Energy Procedia 146, 74-80. 2018

Murakami, T., Kogure, T., Kadohara, H., Ohnuki, T. Formation of secondary minerals and its effect on anorthite dissolution. American Mineralogist 83, 1209-1219. 1998

Murphy, W.M., Pabalan, R.T., Prikryl, J.D., Goulet C.J. Dissolution rate and solubility of analcime at $25^{\circ} \mathrm{C}$. Water-Rock Interact. Proceedings, 7, 107-110. 1992

Murphy, W.M., Pabalan, R.T., Prikryl, J.D., Goulet, C.J. Reaction kinetics and thermodynamics of aqueous dissolution and growth of analcime and Na- clinoptilolite at $25^{\circ} \mathrm{C}$. American Journal of Science 296, 128-86. 1996

Murphy, S.F., Brantley, S.L., Blum, A.E., White, A.F., Dong, H. Chemical weathering in a tropical watershed, Luquillo Mountains, Puerto Rico, II: Rate and mechanism of biotite weathering. Geochimica et Cosmochimica Acta 62, 227-243 1998

Murphy, W.M. and Helgeson, H.C.: Thermodynamic and kinetic constraints on reaction rates among minerals and aqueous soultions. III. Activated complexes and the $\mathrm{pH}-$ dependence of the rates of feldspar, pyroxene, wollastonite and olivine hydrolysis, Geochimica et Cosmochimica Acta 51, 3117--3153. 1987,

Murphy, W.M., Oelkers, E.H., Lichtner, P.C. Surface reaction versus diffusion control of mineral dissolution and growth rates in geochemical processes. Chemical Geology 78, 357-380. 1989

Nagy, K.L. Dissolution and precipitation kinetics of sheet silicates. In: Chemical Weathering Rates of Silicate Minerals (Eds.. A. F. White and S. L. Brantley). Mineralogical Society of America, Washington, DC, Reviews in Mineralogy 31, 173-225. 1995

Nagy, K.L. and Lasaga, A. C. Dissolution and precipitation kinetics of gibbsite at $80^{\circ} \mathrm{C}$ and $\mathrm{pH}$ 3: The dependence on solution saturation state. Geochimica et Cosmochimica Acta 56: 3093-3111. 1992

Nagy, K.L., Blum, A.E., Lasaga, A.C. Dissolution and precipitation kinetics of kaolinite at $80^{\circ} \mathrm{C}$ and $\mathrm{pH}$ 3: the dependence on solution saturation state. American Journal of Science, 291, 649-686. 1991

Navarre-Sitchler, A. and Thyne, G. Effects of carbon dioxide on mineral weathering rates at earth surface conditions. Chemical Geology 243: 53-63. 2007

Nesbitt, H.W., Macrae N.D., Shotyk W. Congruent and incongruent dissolution of labradorite in dilute acidic salt solutions. Journal of Geology 99, 429-442. 1991

Nordstrom, D.K., Plummer, L.N., Langmuir, D., Busenberg, E., May, H.M., Jones, B.F., Parkhurst, D.L., Revised chemical equilibrium data for major water-mineral reactions and their limitations. In: Melchoir and Bassett, R.L. (Eds.), Chemical Modeling of Aqueous Systems II, Chap. 31. American Chemical Society, Washington, DC, 398-413, ACS Symposium Series 416,1991

Nyström Claesson, A., and Andersson, K., PHRQKIN, a program simulating dissolution and precipitation kinetics in groundwater solutions. Computers and Geosciences 22:559-567. 1996.

Numan A-L., and Weaver, C.E. Kinetics of acid-dissolution of palygorskite (attapulgite) and sepiolite. Clays and Clay Minerals, 17, $169-178.1969$.

Oelkers E.H. An experimental study of forsterite dissolution rates as a function of temperature and aqueous $\mathrm{Mg}$ and $\mathrm{Si}$ concentrations. Chemical Geololgy. 175, $485-494$. 2001a

Oelkers, E.H., General kinetic description of multi-oxide silicate mineral and glass dissolution. Geochimica et Cosmochimica Acta 
Oelkers, E.H., and Gislason, S.R. The mechanism, rates, and consequences of basaltic glass dissolution: I. An experimental study of the dissolution rates of basaltic glass as a function of aqueous $\mathrm{Al}, \mathrm{Si}$, and oxalic acid concentration at $25^{\circ} \mathrm{C}$ and $\mathrm{pH}=3$ and 11 . Geochimica et Cosmochimica Acta 65, 3671-3681. 2001

Oelkers, E.H., Schott, J., An experimental study of enstatite dissolution rates as a function of $\mathrm{pH}$, temperature, and aqueous $\mathrm{Mg}$ and $\mathrm{Si}$ concentration, and the mechanism of pyroxene/pyroxenoid dissolution. Geochimica et Cosmochimica Acta 65, 1219-1231. 2001.

Oelkers, E.H. and Schott J. Dissolution and crystallization rates of silicate minerals as a function of chemical affinity. Pure Appl. Chem. 67, 903-910. 1995a

Oelkers, E.H. and Schott J. Experimental study of anorthite dissolution and the relative mechanism of feldspar hydrolysis. Geochimica et Cosmochimica Acta 59, 5039 - 5053. 1995b

Oelkers, E.H. and Schott J. Does organic acid adsorption affect alkali-feldspar dissolution rates? Chemical Geology 151, $235-245$. 1998

Oelkers, E. H. and Schott J. Experimental study of kyanite dissolution rates as a function of chemical affinity and solution composition. Geochimica et Cosmochimica Acta. 63, 785-797. 1999

Oelkers, E.H., Schott, J., Devidal, J.-L. The effect of aluminum, pH, and chemical affinity on the rates of aluminosilicate dissolution rates. Geochimica et Cosmochimica Acta 58, 2011-2024. 1994

Oelkers, E H., Schott, J., Gauthier, J.M., Herrero-Roncal, T. An experimental study of the dissolution mechanism and rates of muscovite. Geochimica et Cosmochimica Acta 72, 4948-4961. 2008

Oelkers, E.H., and Pointrasson, F., An experimental study of the dissolution stoichiometry and rates of a natural monazite as a function of temperature from 50 to $230 \mathrm{C}$ and $\mathrm{pH}$ from 1.5 to 10 . Chemical Geology 191, 73-87. 2002

Oelkers, E.H., Benning, L.G., Lutz, S., Mavromatis, V., Pearce, C.R., Plümper, O., The efficient long-term inhibition of forsterite dissolution by common soil bacteria and fungi at Earth surface conditions. Geochimica et Cosmochimica Acta 168, $222-235$. 2013

Oelkers, E.H., Declercq, J., Saldi, G.D., Gislason, S.R., Schott, J., Olivine dissolution rates: A critical review. Chemical Geology 500, 1-19. 2018

Olsen, A.A.. Forsterite dissolution kinetics: Applications and implications for chemical weathering. Dissertation submitted to the faculty of the Virginia Polytechnic Institute and State University In: Geosciences. June 21, 2007 Blacksburg, Virginia. 2007

Olsen, A.A., Rimstidt, D.J., Oxalate-promoted forsterite dissolution at low pH. Geochimica et Cosmochimica Acta $72,1758-1766$. 2008.

Olsson, M., Rosén, K., Melkerud, P.-A. Regional modelling of base cation losses from Swedish forest soils due to whole-tree harvesting. Applied Geochemistry, Suppl. Issue No.2, 189-194. 1993

Opolot, E and Finke, P. Sensitivity of mineral dissolution rates to physical weathering: A modeling approach. Geophysical Research Abstracts Vol. 17, EGU2015-1807. 2015

Oxburgh, R. The effect of $\mathrm{pH}$, oxalate ion, and mineral composition on the dissolution rates of plagioclase feldspars. M.S. Thesis, University of Wyoming, Laramie, Wyo., 69 pp. 1991

Oxburgh, R., Drever, J.I., Sun, T.-Y. Mechanism of plagioclase dissolution in acid solution at $25^{\circ} \mathrm{C}$. Geochimica et Cosmochimica Acta, 58: 661-669. 1994

Palandri, J.L. and Kharaka, Y.K. A compilation of rate parameters of water-mineral interaction kinetics for application to geochemical modeling, U.S.G.S Open file report 2004-1068, 64p. 2004

Parkhurst, D.L., Thorstenson, D.C., Plummer, L.N., PHREEQE-A computerized program for geochemical calculations. Water Resources Invest. 80-96, U.S. Geol. Survey. 1980

Phelan, J., Belyazid, S., Kurz, D., Guthrie, S., Cajka, J., Sverdrup, H., Waite, R. Estimation of soil base Cation weathering rates with the PROFILE model to determine critical loads of acidity for forested ecosystems in Pennsylvania, USA; Pilot application of a potential National methodology. Water, Air and Soil Pollution, 225: 2109-2128. 2014

Phelan, J., Belyazid, S., Jones, P., Cajka, J., Buckley, J., Clark, C.: Assessing the Effects of Climate Change and Air Pollution on Soil Properties and Plant Diversity in Northeastern U.S. hardwood forests: Model simulations from 1900 - 2100. Water, Air and Soil Pollution, 227:84, 2016.

Pokrowsky, O.S. and Schott, J. Kinetics and mechanism of forsterite dissolution at $25^{\circ} \mathrm{C}$ and $\mathrm{pH}$ from 1 to 12 . Geochimica et Cosmochimica Acta. 64, 3313-3325. 2000a

Pokrovsky, O.S.,and Schott, J., Forsterite surface composition in aqueous solutions: a combined potentiometric, electrokinetic, and spectroscopic approach. Geochimica et Cosmochimica Acta 64, 3299-3312. 2000b.

Pokrovsky, O.S. and Schott, J. Surface chemistry and dissolution kinetics of divalent metal carbonates. Environ. Sci. Technol. 36, $426-432.2002$

Pokrovsky, O.S., Golubev, S.V., Schott, J. Impact of dissolved organics on mineral dissolution kinetics: towards a predictive model for Ca- and Mg-bearing oxides, carbonates and silicates. Abstract 13th V.M. Goldschmidt Conference, Copenhagen, Denmark. June 5-11, 2004. Geochimica et Cosmochimica Acta. 68, A141. 2004

Porter, E., Sverdrup, H., Sullivan, T. Estimating and mitigating the impacts of climate change and air pollution on alpine plant communities in National parks, Park Science Journal. 28:58-64. 2011.

Posch M., and Kurz D. A2M - A program to compute all possible mineral modes from geochemical analyses. Computers \& Geosciences 33: 563-572. 2007

Posch, M., Kurz, D., Alveteg, M., Akselsson, C., Eggenberger, U., Holmqvist, J; A2M, a model to quantify mineralogy from

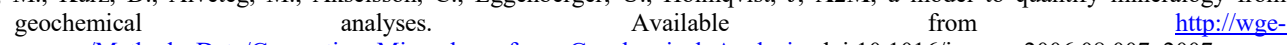
cce.org/Methods_Data/Computing_Mineralogy_from_Geochemical_Analysis; doi:10.1016/j.cageo.2006.08.007. 2007

Posch, M., Hettelingh, J.-P., de Vries, W., Sverdrup, H., Wright, R.F. Manual for dynamic modelling of soil response to atmospheric deposition. UN/ECE Convention on long-range transboundary air pollution. Working group on effects/ICP on modelling and mapping. Coordination center for effects (CCE). RIVM/MNV, Bilthoven, Netherlands. 2006

Poulson S.R., Drever J.I., and Stillings L.L. Aqueous Si-oxalate complexing, oxalate adsorption onto quartz, and the effect of oxalate upon quartz dissolution rates. Chemical Geololgy 140, 1-7. 1997 
1631

Prajapati, P.R., Srinivasan, T.G., Chandramouli, V., Bhagwat, S.S. Dissolution kinetics of zirconium dioxide in nitric acid. Desalination and Water Treatment. 2 490-497. 2014

Price, J., and Velbel, M.A. Rates of Biotite Weathering, and Clay Mineral Transformation and Neoformation, Determined from Watershed Geochemical Mass-Balance Methods for the Coweeta Hydrologic Laboratory, Southern Blue Ridge Mountains, North Carolina, USA. Aquatic Geochemistry. 20. 10.1007/s10498-013-9190-y 2004

Price, J.R, Velbel, M.A., Patino, L.A., Allanite and epidote weathering at the Coweeta Hydrologic Laboratory, western North Carolina, U.S.A American Mineralogist 90: 101-114. 2005.

Price, J.R.; Bryan-Ricketts, D.S.; Anderson, D.; Velbel, M.A. Weathering of almandine garnet: influence of secondary minerals on the rate-determining step, and implications for regolith-scale Al mobilization. Clays and Clay Minerals 61:34-56. 2013.

Prigiobbe V., Costa G., Baciocchi R., Hanchen M. and Mazzotti M. The effect of $\mathrm{CO}_{2}$ and salinity on olivine dissolution kinetics at $120^{\circ} \mathrm{C}$. Chemical Engineering Science 64, 3510-3515. 2009

Probst, A., Obeidy, C., Gaudio, N., Belyazid, S., Gégout, J.-C., Alard, D., Corket, E., Party, J-P., Gauquelin, T., Mansat, A., Nihlgård, B., Leguédois S., Sverdrup H.U. Evaluation of plant-responses to atmospheric nitrogen deposition in France using integrated soil-vegetation models. In: W. de Vries, J-P. Hettelingh, M. Posch (Eds.) Critical Loads and Dynamic Risk Assessments: Nitrogen, Acidity and Metals in Terrestrial and Aquatic Ecosystems: 359-379. Springer Verlag, 2015

Ouimet, R. and Duchesne, L. Base cation mineral weathering and total release rates from soils in three calibrated forest watersheds on the Canadian Boreal Shield. Canadian Journal of Soil Science 85: 245-260. 2005

Ragnarsdottir K.V. Dissolution kinetics of heulandite at pH 2-12 and 25ㄷ. Geochimica et Cosmochimica Acta 57:2439-2449. 1993

Ragnarsdottir, K.V., Graham, C.M., Allen, G.C. Surface chemistry of reacted heulandite determined by SIMS and XPS. Chemical Geolology 131, 167-181. 1996

Raschman, P.,Fedorockova, A., Dissolution kinetics of periclase in dilute hydrochloric acid. Chemical Engineering Science 63, 576586. 2008.

Rietz, F. Modeling mineral weathering and soil chemistry during post-glacial period., Reports in Ecology and Environmental Engineering, 1;1995. Department of Chemical Engineering, Lund University ISRN LUTKDH/TKKT-3004-SE. 1995

Rimstidt, J.D., Brantley, S.L., Olsen, A.A. Systematic review of forsterite dissolution rate data. Geochimica et Cosmochimica Acta 99, 159-178. 2012.

Rizzetto, S., Belyazid, S., Gegout, J-C., Nicholas, M., Alard, D., Corcket, E., Gaidio, N., Sverdrup, H., Probst, A., Modelling the impact of climate change and atmospheric N deposition on French forests biodiversity. Environmental Pollution 213: 1016-1027. 2016.

Rizzetto, S.; Gégout, J.-.C; Belyazid, S.; Kuhn, E.; Sverdrup, H.; Probst, A., How to couple ecological database to geochemical dynamic model to predict the impact of atmospheric nitrogen deposition and climate change on French forest ecosystems at the national scale? International Congress on Environmental Modelling and Software. 75. https://scholarsarchive.byu.edu/iemssconference/2016/Stream-D/75. 2016.

Roberts, N., Andersen, D.F., Deal, R.M., Shaffer, W.A. 1982, Introduction to Computer Simulation: A System Dynamics Approach Productivity Press, Chicago

Ross, G.J., Acid dissolution of chlorites: release of magnesium, iron and aluminum and mode of acid attack. Clays and Clay Minerals, 17, 347-354. 1969

Rosso, J.J., and Rimstidt, J.D. A high resolution study of forsterite dissolution rates. Geochimica et Cosmochimica Acta, 64, 797811. 1999

Rozalen, M., Ramos, M.E., Gervilla, F., Kerestedjian, T., Fiore, S., Huertas, F.J. Dissolution study of tremolite and anthophyllite: pH effect on the reaction kinetics. Applied Geochemistry 49:46-56. 2014

RTI International. 2013. Application of the base cation weathering (BCw) methodology and PROFILE model to calculate terrestrial critical acid loads in Pennsylvania - evaluation of USGS landscapes project database as source of soil mineralogy data. Final report. pp. 85. Google Scholar. 2013

Running, S.W. and Gower, S.T. FOREST-BGC, a general model of forest ecosystem processes for regional applications, II. Dynamic carbon allocation and nitrogen budgets. Tree Physiology, 9, 147-160. 1991

Running, S.W. Testing FOREST-BGC ecosystem process simulations across a climatic gradient in Oregon. Ecol. Appl., 4, $238-247$. 1994

Saldi, G.D., Köhler, S.J., Marty, N., Oelkers, E.H.,. Dissolution rates of talc as a function of solution composition, $\mathrm{pH}$ and temperature. Geochimica et Cosmochimica Acta 71, 3446-3457. 2007

Savage, D., Rochelle, C., Moore, Y., Milodowski, A., Bateman, K., Bailey, D., Mihara, M., Analcime reactions at $25-90^{\circ} \mathrm{C}$ in hyperalkaline fluids Mineralogical Magazine, 65, 571-587. 2001.

Schnoor, J.L. Kinetics of chemical weathering: a comparison of laboratory and field weathering rates. In: Aquatic Chemical Kinetics (ed. W. Stumm). Wiley, New York, 475-504. 1990

Schofield, R.E., Hausrath, E.M., and Gainey, S.R. Zeolite weathering in laboratory and natural settings, and implications for mars. 46th Lunar and Planetary Science Conference 2160.pdf. 2015

Schott, J., Oelkers, E.H., Dissolution and crystallization rates of silicate minerals as a function of chemical affinity. Pure and applied chemistry 67, 903-910. 1995

Schott, J., Pokrovsky, O.S., Oelkers, E.H. The Link Between Mineral Dissolution/Precipitation Kinetics and Solution Chemistry. Reviews in Mineralogy and Geochemistry 70: 207-258. 2009

Schott, J., Oelkers, E., Benezeth, P., Godderis, Y. Francois, L. Can accurate kinetic laws be created to describe chemical weathering? Comptes Rendus Geoscience 344, 568-585. 2012

Semenov, M., Bashkin, V., Sverdrup, H., Application of biochemical model PROFILE for assessment of North Asian ecosystem sensitivity to acid deposition. Asian Journal of Energy and Environment 1:143-161. 2000

Senge P. The Fifth Discipline. The Art and Practice of the Learning Organisation. Century Business, New York. 1990

Smits, M.M., and Wallander, H. Role of Mycorrhizal Symbiosis in Mineral Weathering and Nutrient Mining from Soil Parent Material. in Mycorrhizal Mediation of Soil: Fertility, Structure, and Carbon Storage. Elsevier Inc., pp. 35-46. DOI: 10.1016/B978-0-12804312-7.00003-6. 2016

Smits, M.M., Johansson, L., Wallander, H. Soil fungi appear to have a retarding rather than a stimulating role on soil apatite weathering. Plant and Soil 385: 217-228. 2014. 
Smith, M.M., Wolery, T.J., Carroll, S.A., Kinetics of chlorite dissolution at elevated temperatures and $\mathrm{CO}_{2}$ conditions. Chemical Geology 347, 1-8. 2013.

Soler, J.M., Cama, J., Galí, S., Meléndez, W., Ramírez, A., Estanga, J. Composition and dissolution kinetics of garnierite from the Loma de Hierro Ni-laterite deposit, Venezuela Journal of Chemical Geology 249, 191-202. 2008

Starr, M., Lindroos, A.J., Tarvainen, T., Tanskanen, H., Weathering rates in the Hietajärvi Integrated Monitoring catchment. Boreal Environment Research 3: 275-285. 1998

Stegman B., and Sverdrup, H. Skogsmarkens försurning i Värmland - En prognos för framtiden. Länsstyrelsen i Värmlands Län, Miljöenheten Rapport 1997:11A:1-40. 1997

Stegman B., Sverdrup, H. Skogsmarkens försurningskännslighet, kritisk belastning och modelberäkning. Länsstyrelsen i Älvsborgs Län, Miljöenheten Meddelande 1996:8:1-40. 1996

Stendahl, J., Akselsson, C., Melkerud, P.A., Belyazid, S.. Pedon-scale silicate weathering: Comparison of the PROFILE model and the depletion method at 16 forest sites in Sweden. Geoderma. 211-212. 65-74. 2013.

Stephens, J.C., and Hering, J.G. Factors affecting the dissolution kinetics of volcanic ash soils: dependencies on $\mathrm{pH}, \mathrm{CO}_{2}$, and oxalate Applied Geochemistry 19: 1217-1232. 2003

Stillings, L., Brantley, S. and Machesky, M., Proton adsorption at an adularia feldspar surface, Geochimica et Cosmochimica Acta 59, 1473-1482. 1995

Stillings L.L. and Brantley S.L. Feldspar dissolution at $25^{\circ} \mathrm{C}$ and $\mathrm{pH}$ 3: reaction stoichiometry and the effect of cations. Geochimica et Cosmochimica Acta 59, 1483-1496. 1995

Stillings L.L., Drever J.I., Brantley S.L., Sun Y., Oxburgh R. Rates of feldspar dissolution at pH 3-7 with 0-8 mM oxalic acid. Chemical Geology 132, 79-89. 1996

Stockmann G., Wolff-Boenisch D., Gislason S.R., Oelkers E.H. Dissolution of diopside and basaltic glass: the effect of carbonate coating. Mineralogical Magazine 72, 135-139. 2008

Stockmann, G.J., Wolff-Boenisch, D., Gislason, S.R., Oelkers, E.H., Do carbonate precipitates affect dissolution kinetics?: 2: Diopside. Chemical Geology 337, 56-66 2013

Stumm, W. and Wieland, E., Dissolution of oxide and silicate minerals; rates depend on surface speciation. In: Stumm, W. Ed.., Aquatic Chemical Kinetics. Wiley-Interscience, New York. 1990

Stumm, W. and Wollast, R., Coordination chemistry of weathering. Rev. Geophys. 28, 53-69. 1990

Sverdrup, H. Calcite dissolution and acidification mitigation strategies, Lake and Reservoir Management 2:345-355. 1984

Sverdrup, H.U., Calcite dissolution kinetics and lake neutralization. PhD Thesis, Chemical Engineering, Lund University. LUTTKDH/TKKT/1002/1-169/1985. 169pp. 1985.

Sverdrup, H. The kinetics of chemical weathering. Lund University Press, Lund, Sweden and Chartwell-Bratt Ltd, London, ISBN 0$86238-247-5,245$ pp. 1990

Sverdrup, H. Methods for the estimation of base cation weathering rates. In; Annex IV; In: Bobbink, R., Draajers, G., Erisman, J., Gregor, H.D., Henriksen, A., Hornung, M., Iversen, T., Kucera, V., Posch, M., Rihm, B., Spranger, T., Sverdrup, H., de Vries, W., Werner, B. In: Gregor H. D. and Werner B. (Eds.): Manual on methodologies and criteria for mapping critical levels/loads and geographical areas where they are exceeded. Umweltbundesamt Texte 71:96, ISSN 0722-186X. 1996.

Sverdrup, H. Geochemistry, the key to understanding environmental chemistry. Science of the Total Environment 183, 67-87. 1996

Sverdrup, H. Experimental kinetics of hornblende and epidote and their importance in integrated soil modelling. In: Sulovsky P., and Zeman, J., (Eds), Environmental aspects of weathering processes. Masaryk University Faculty of Science; 208-216. 1998

Sverdrup, H. What is left for researchers in soil and water acidification modelling? Reflections over past experiences and future possibilities. In: Guardans, R. Data analysis for modelling and assessment of biogeochemical effects of air pollution in temperate ecosystems. Pages 49-60. CIEMAT, Madrid, Spain 8-11 October 1997. 1998.

Sverdrup, H. Calculating critical loads of acidity and nitrogen for terrestrial ecosystems and some reflections on the Alberta situation In K. Foster (Ed.), Proceedings of the NOx/SOx management working group science colloquium on acid deposition, Alberta Research Council Reports; 9-14, Edmonton. 2000

Sverdrup, H. Nutrient sustainability for Swedish forests In: Developing principles for sustainable forestry Results from a research program in southern Sweden. Sverdrup, H., and Stjernquist, I., (Eds.) Managing Forest Ecosystems 5:427-432 Kluwer Academic Publishers, Amsterdam. 2002

Sverdrup, H. Chemical weathering of soil minerals and the role of biological processes. Fungal Biology Reviews 23:94-100. 2009.

Sverdrup, H. and Alveteg, M. PROFILE - The integrated model for transferring laboratory weathering kinetics to field conditions. In: Sulovsky P., and Zeman, J., (Eds), Environmental aspects of weathering processes, Masaryk University Faculty of Science; 218-224. 1998

Sverdrup, H. and Bjerle, I. Dissolution of calcite and other related minerals in aqueous solutions in a pH-stat, Vatten, Journal of Water Management and Research 38:59-73. 1982

Sverdrup, H., and Belyazid, S. The ForSAFE-VEG model system - Developing an approach for Sweden, Switzerland, United States and France for setting critical loads based on biodiversity in a time when management, pollution and climate change. Ecological Modelling 306: 35-45, Special Issue for the 2013 ISEM Conference at Toulouse. (Invited keynote lecture paper, doi:10.1016/j.ecolmodel.2014.09.020). 2014.

Sverdrup, H., Holmqvist, J., A critical assessment of the use of kinetics, steady state or equilibrium in relation to reversibility or irreversibility in chemical weathering rate modelling (Unpublished note available as pdf from Sverdrup). 2019

Sverdrup, H. and Rosén, K. Long-term base cation mass balances for Swedish forests and the concept of sustainability. Forest Ecology and Management 110, 221-236. 1998.

Sverdrup, H. and Stiernquist, I. Developing Principles and Models for Sustainable Forestry in Sweden. Kluwer Academic Publishers, Dordrecht, 480 pp. 2002.

Sverdrup, H. and Warfvinge, P. Chemical weathering of minerals in the Gårdsjön catchment in relation to a model based on laboratory rate coefficients. In; Critical loads for sulphur and nitrogen, Nilsson, J., (Ed) Nordic Council of Ministers and The United Nations Economic Commission for Europe (UN/ECE). Stockholm, Nordic Council of Ministers Miljörapport 1988:15:131150. $1988 \mathrm{a}$

Sverdrup, H. and Warfvinge, P. Assesment of critical loads of acid deposition on forest soils, In: Critical loads for sulphur and nitrogen, Nilsson, J., (Ed) Nordic Council of Ministers and The United Nations Economic Commission for Europe (ECE), 
Stockholm Nordic Council of Ministers Miljörapport 1988:15:81-130. 1988b

Sverdrup, H. and Warfvinge, P. Weathering of primary silicate minerals in the natural soil environment in relation to a chemical weathering model, Water, Air and Soil Pollution 38:387-408. 1988c

Sverdrup, H. and Warfvinge, P., The role of weathering in determining the acidity of lakes in Sweden. Water, Air and Soil Pollution, 52:71-78. 1990

Sverdrup, H. and Warfvinge, P. On the geochemistry of chemical weathering. In: Rosen, K., (Ed.) Chemical weathering under field conditions: 79-118. Department of Forest Soils. Swedish Agricultural University. 1991

Sverdrup, H. and Warfvinge, P. PROFILE-A mechanistic geochemical model for calculation of field weathering rates. In: Kharka, Y. and Maest, A. (Eds.), Proceedings of the 7th International Symposium on water-rock interaction, Utah, 13-19 July 1992, 44 48. Balkemaa Publishers. 1992a

Sverdrup, H. and Warfvinge, P. PROFILE-A mechanistic geochemical model for calculation of field weathering rates. In: Y. Kharka and A. Maest (Eds.), Proceedings of the 7th International Symposium on water-rock interaction, Utah, 13-19 July 1992, 44 48. Balkemaa Publishers. 1992b

Sverdrup, H. and Warfvinge, P. Critical loads. In Warfvinge, P. and Sandén, P. editors, Modeling Acidification of Groundwater. SMHI, Norrköping, 171-186. 1992c

Sverdrup, H. and Warfvinge, P. Calculating field weathering rates using a mechanistic geochemical model-PROFILE. Journal of Applied Geochemistry, 8:273-283. 1993

Sverdrup, H. and Warfvinge, P. Estimating field weathering rates using laboratory kinetics. In: White, A.F., Brantley, S.L., (Eds.), Chemical weathering rates of silicate minerals. Mineralogical Society of America, Washington DC. Reviews in Mineralogy, 31:485-541. 1995

Sverdrup, H., Alveteg, M., Langan, S., Paces, T. Biogeochemical modelling of small catchments using PROFILE and SAFE. In S. Trudgill, (Ed), Solute Modelling in Catchment Systems, 75-99. John Wiley Science, New York. 1995

Sverdrup H., Belyazid S., Nihlgard B., Ericson L. Modelling change in ground vegetation response to acid and nitrogen pollution, climate change and forest management in Sweden 1500-2100 A.D. Water Air and Soil Pollution: Focus 7: 163-179. 2007

Sverdrup, H., Belyazid, S., Kurz, D., Braun, S. A proposed method for estimating critical loads for nitrogen based on biodiversity using a fully integrated dynamic model, with testing in Switzerland and Sweden. In: Sverdrup, H., (Ed.) Towards critical loads for nitrogen based on biodiversity. Background document for the 18th CCE workshop on the assessment of nitrogen effects under the ICP for Modelling and Mapping, LRTAP Convention (UNECE), Bern, Switzerland, 21-25 April 2008. Pages 3-37. Swiss Federal Office of the Environment (FOEN), Bern, Switzerland. 2008

Sverdrup, H., Belyazid, S., Akselsson, C., Posch, M. Assessing critical loads for nitrogen under climate change based on chemical and biological indicators in a sub-Arctic country; the case of Sweden. In: Bashkin, V., (Ed.); Ecological and biogeochemical cycling in impacted polar ecosystems. Nova Science Publishing, Hauppage, New York. ISBN 978-1-53612-081-3. 2017.

Sverdrup, H., Hagen-Thorn, A., Holmqvist, J., Warfvinge, P., Walse, C., Alveteg, M. Biogeochemical processes and mechanisms. In: Developing principles for sustainable forestry Results from a research program in southern Sweden. Sverdrup, H., and Stjernquist, I. (Eds.) Managing Forest Ecosystems 5:91-196. Kluwer Academic Publishers, Amsterdam. 2002

Sverdrup H. (Ed.), Haraldsson, H., Koca, D., Belyazid, S. 2011 System Thinking, System Analysis and System Dynamics: Modelling Procedures for Communicating Insight and Understanding by Using Adaptive Learning in Engineering for Sustainability. $1^{\text {st }}$ edition for Iceland. Two volumes, 30 printed. Háskolaprent Reykjavik. 310pp. 2011

Sverdrup, H., Holmqvist, J., Butz-Braun., R., Clay-PROFILE - A new concept for modelling clay weathering rates and alteration sequences. (Unpublished note, available as pdf). 2010

Sverdrup, H., Hoyesky, H., Achermann B. Critical loads of acidity for high precipitation areas. Bundesministerium fuer Umwelt, Jugend und Familie, Wien. 60pp. 1993

Sverdrup, H., Martinsson, L., Alveteg, M., Moldan, F., Kronnäs, V., Munthe, J. Modeling recovery of Swedish ecosystems from acidification, Ambio 34:25-31. 2005

Sverdrup, H., McDonnell, T.C., Sullivan, T.J., Nihlgård, B., Belyazid, S., Rihm, B., Porter, E., Bowman, W.D., Geiser, L. Testing the feasibility of using the ForSAFE-VEG model to map the critical load of nitrogen to protect plant biodiversity in the Rocky Mountains region, USA. Water, Air and Soil Pollution, 223:371-387. 2012.

Sverdrup, H., Nihlgård, B., Svensson, M., Örlander. G. Skogsmarkens långsiktiga produktionsförmåga. In: J. Elmberg (Ed.) Sustainable Forestry in Southern Sweden, Årsrapport 1998; Tema Skogshälsa 37-39. 1998

Sverdrup H., de Vries W., Henriksen A. Mapping Critical Loads. Environmental Report 1990:14 (NORD 1990:98), Nordic Council of Ministers, Copenhagen, 124 pp. 1990

Sverdrup, H., Warfvinge, P., Bjerle, I. Opplösningskinetikken for K-kalk i forhold till andre basiske mineral benyttet for nöytralisasjon av surt vann, Swedish Environmental Protection Board (SNV), Solna, Sweden SNV Report 3020. 1985

Sverdrup, H., Warfvinge, P., Bjerle, I. Experimental determination of the kinetic expression for K-slag, a tricalcium silicate, in acidic aqueous solution at $25^{\circ} \mathrm{C}$ and in equilibrium with air, using the results from $\mathrm{pH}$-stat experiments. Vatten, Journal of Water Management and Research. 42:210-217. 1986

Sverdrup, H., Warfvinge, P., von Brömssen, U. A mathematical model for podzolic soil profiles exposed to acidic deposition. In: Acidification and water pathways, N. Christophersen (Ed), 435-444, ISBN 82-554-0486-4. Norwegian National Committee for Hydrology 1987a

Sverdrup, H., Warfvinge, P., von Brömssen, U. A mathematical model for acidification and neutralization of soil profiles exposed to acid deposition. In; Air pollution and ecosystems-Proceedings of an International symposium held in Grenoble, France, 1822 May, 1987, Mathy, P, (Ed) 817-822, D. Reidel publishing company, Dordrecht. 1987b

Sverdrup, H., Warfvinge, P., Blake, L., Goulding, K. Modeling recent and historic soil data from the Rothamsted Experimental Station UK, using SAFE. Agriculture, Ecosystems and Environment, 53:161-177. 1995

Sverdrup, H., Warfvinge, P., Wickman, T. Estimating the weathering rate at Gårdsjön using different methods. In: Hultberg H. and Skeffington R. (Eds.) Experimental reversal of acid rain effects; The Gårdsjön roof project: 231-250. John Wiley Science. 1998

Sverdrup, H., Warfvinge, P., Frogner, T., Håöya, A.O., Johansson, M., Andersen, B. Critical loads for forest soils in the Nordic countries. Ambio, 21:348-355. 1992

Sverdrup, H, Warfvinge, P, Moldan, F. Hultberg, H., Modelling acidification and recovery in the roofed catchment at Lake Gårdsjön 
using the SAFE model. Water, Air and Soil Pollution 85:1753-1758. 1996

Sverdrup, H., Warfvinge, P., Janicki A., Morgan, R., Rabenhorst, M., Bowman, M. Mapping critical loads and steady state stream chemistry in the state of Maryland. Environmental Pollution, 77:195-203. 1992

Sverdrup, H., Warfvinge, P., Rosen, K. Critical loads of acidity and nitrogen for Swedish forest ecosystems, and the relationship to soil weathering. In: H. Raitio and T. Kilponen, (Eds), Critical loads and critical limit values, Metsäntutkimuslaitoksen tiedonantoja 513:109-138, Vaasa, Finland 1994

Sverdrup, H., Warfvinge, P., Britt, D. Assessing the potential for forest effects due to soil acidification in Maryland. Water, Air and Soil Pollution 87:245-265. 1996

Sverdrup, H., Warfvinge, P., Hultberg, H., Andersson, B., Moldan, F. Modelling soil acidification and recovery in a roofed catchment; Application of the SAFE model. In: Hultberg H. and Skeffington R. (Eds.) Experimental reversal of acid rain effects; The Gårdsjön roof project: 363-382. John Wiley Science. 1998

Sverdrup, H., Thelin, G., Robles, M., Stjernquist, I., Sörensen, J. Assessing sustainability of different tree species considering Ca, Mg, K, N and P at Björnstorp Estate. Biogeochemistry 81:219-238. 2006.

Swoboda-Colberg N.G. and Drever J.I. Mineral dissolution rates in plot-scale field and laboratory experiments. Chemical Geology 105, 51-69. 1993

Taylor, A.S., Blum, J.D., Lasaga, A.C., MacInnis, I.N. Kinetics of dissolution and Sr release during biotite and phlogopite weathering. Geochimica et Cosmochimica Acta, 64:. 1191-1208. 1999.

Taylor, A.S., Blum, J.D., Lasaga, A.C. The dependence of labradorite dissolution and Sr isotope release rates on solution saturation state. Geochimica et Cosmochimica Acta 64, 2389-2400. 2000

Taylor, A. and Blum, J.D. Relation between soil age and silicate weathering rates determined from the chemical evolution of a glacial chronosequence. Geology 23: 979-982. 1995.

Taylor, L.L., Beerling, D.J., Quegan, S., Banwart, S.A. Simulating carbon capture by enhanced weathering with croplands: an overview of key processes highlighting areas of future model development. Biol. Lett. 13 : 20160868. http://dx.doi.org/10.1098/rsbl.2016.0868. 2017

Techer, I, Advocat, T, Vernaz, E., Lancelot, J.R., Liotard, J.M. Toulouse Goldschmidt Conference. Mineralogical Magazine, 62a: 1498-1499. 1998

Teir, S., Revitzer, H., Eloneva, S., Fogelholm, C-J., Zevenhoven, R. Dissolution of natural serpentinite in mineral and organic acids. Int. J. Miner. Process. 83 36-46. 2007

Terry, B., The acid decomposition of silicate minerals Part I. Reactivities and modes of dissolution of silicates. Hydrometallurgy 10 , 135-150. 1983a.

Terry, B., The acid decomposition of silicate minerals Part II. Hydrometallurgical applications. Hydrometallurgy 10, $151-171$. 1983b.

Terry, B., Specific chemical rate constants for the acid dissolution of oxides and silicates. Hydrometallurgy 11, 315-344. 1983c.

Terry, B., Monhemius, A.J. Acid dissolution of willemite $(\mathrm{Zn}, \mathrm{Mn})_{2} \mathrm{SiO}_{4}$ and hemimorphite $\left(\mathrm{Zn}_{4} \mathrm{Si}_{2} \mathrm{O}_{7}(\mathrm{OH})_{2} \mathrm{H}_{2} \mathrm{O}\right)$. Metall. Trans. B 14, 335-346. 1983.

Thelin, G., Sverdrup, H., Holmqvist, J., Rosengren, U., Linden M. Sustainability in spruce and mixed forest stands. In: Developing principles for sustainable forestry Results from a research program in southern Sweden. Sverdrup, H., and Stjernquist, I., (Eds.) Managing Forest Ecosystems 5:337-354, Kluwer Academic Publishers, Amsterdam. 2002

Thom, J.G.M., Dipple, G.M., Power, I.M., Harrison, A.L. Chrysotile dissolution rates: implication for carbon sequestration. Applied Geochemistry 35, 244-254. 2013

Tominaga, K., Aherne, J., Watmough, S.A., Alveteg, M., Cosby, B.J., Driscoll, C.T., Posch, M., Pourmokhtarian, A., Predicting Acidification Recovery at the Hubbard Brook Experimental Forest, New Hampshire: Evaluation of Four Models Environmental Science \& Technology. 44, 9003-9009. 2010

Traven, L., Fijan-Parlov, S., Galović, L., Sverdrup, H.: Prospects for a regional assessment of forest soil chemistry dynamics in Croatia: Application of the SAFE model to a forested site in the region of mount Medvednica. Periodicum Biologorum 01/2005; 107:17-26. 2005

Turpault, M.P., and Trotignon, L. The dissolution of biotite single crystals in dilute $\mathrm{HNO}_{3}$ at $24^{\circ} \mathrm{C}$; evidence of an anisotropic corrosion process of micas in acidic solution. Geochimica et Cosmochimica Acta 58, 2761-2775. 1994

Ullman, W.J., Kirchman, D.L., Welch, S.A., Vandevivere P. Laboratory evidence for microbially mediate silicate dissolution in nature. Chemical Geology 132, 11-17. 1996

Valsami-Jones, E., Ragnarsdottir, K.V., Putnis, A., Bosbach, D., Kemp, A.J., Cressey, G. The dissolution of apatite in the presence of aqueous metal cations at $\mathrm{pH}$ 2-7. Chemical Geology 151:215-233. 1998

Velbel., M.A., Bond strength and the relative weathering rates of simple orthosilicates. American Journal of Science 299, 679-696. 1999

Velbel M.A. Constancy of silicate-mineral weathering-rate ratios between natural and experimental weathering: Implications for hydrologic control of differences in absolute rates. Chemical Geology 104, 89-99. 1993

de Vries W., Wamelink, W., Dobben, H., Kros, H., Reinds, G. J., Mol-Dijkstra, J., Smart, S., Evans, C., Rowe, E., Belyazid, S., Sverdrup, H., Hindsberg, A., Posh, M., Hettelingh, J-P., Spanger, T., Bobbink, R. Use of dynamic soil-vegetation models to assess impacts of nitrogen deposition on plant species composition: an overview. Ecological Applications 20: 60-79; DOI: 10.1890/08-1019.1 2010.

de Vries, W., Kros, H., Reinds, G. J., Wamelink, W., van Dobben, H., Bobbink, R., Smart, S., Evans, C., Schlütow, A., Kraft, P., Belyazid, S., Sverdrup, H., van Hinsberg, A., Posch, M., Hettelingh J-P. Developments in modelling critical nitrogen loads for terrestrial ecosystems in Europe 230pp, Developments in Deriving Critical Limits and Modeling Critical Loads of Nitrogen for Terrestrial Ecosystems in Europe. Alterra, CCE Report critical N limits and loads CCE. 174 ISSN 1566-7197 (C2006 Alterra, Box 47,6700 AA Wageningen; The Netherlands; e-mail: info.alterra@wur.nl. 2006

Voltini, M., Artioli, G., Moret, M. The dissolution of laumontite in acidic aqueous solutions: A controlled-temperature in situ atomic force microscopy study American Mineralogist, 97: 150-158, 2012.

Wallman, P., Svensson, M.G.E., Sverdrup, H., Belyazid, S., ForSAFE - an integrated process-oriented forest model for long-term sustainability assessments, Forest Ecology and Management, 207:19-36. 2005.

Wallman, P., Sverdrup, H. Developing the complex forest ecosystem model FORSAFE - motives, means and the learning loop. In; 
https://doi.org/10.5194/bg-2019-464

Preprint. Discussion started: 27 March 2020

(c) Author(s) 2020. CC BY 4.0 License.

Björk, L. (Ed.) Sustainable Forestry in Temperate Regions. Proceedings of the SUFOR International Workshop, April 7-9, 2002 in Lund, Sweden: page 154. 2002.

Wang, F., Silicate Mineral Dissolution and Associated Carbonate Precipitation at Conditions Relevant to Geologic Carbon $\begin{array}{lllllll}\text { Sequestration. All Theses and Dissertations (ETDs). PhD } & & \text { thesis. }\end{array}$ http://openscholarship.wustl.edu/etd/1161 170pp. 2013

Wang, F., Giammar, D.E. Forsterite dissolution in saline water at elevated temperature and high $\mathrm{CO}_{2}$ pressure. Environ. Sci. Technol. 47, 168-173. 2012

Wang, H., Feng, Q., Rang, X., Zuo, K., Liu, K., Insights into alkali-acid leaching of sericite: Dissolution behaviour and mechanism. Minerals 7: 196-208. 2017.

Warfvinge, P., and Sverdrup, H., Soil liming and runoff acidification mitigation, Lake and Reservoir Management 2:389-393. 1984

Warfvinge P. and Sverdrup H. Calculating critical loads of acid deposition with PROFILE - A steady-state soil chemistry model Water, Air and Soil Pollution 63: 119-143. 1992a

Warfvinge, P. and Sverdrup, H. Hydrochemical modeling 79-118. In: Warfvinge, P. and Sandén, P., (Eds.), Modeling Acidification of Groundwater. SMHI, Norrköping. 1992b.

Warfvinge, P. and Sverdrup, H. Scenarios for acidification of groundwater 147-156. In: Warfvinge, P. and Sandén, P. (Eds.), Modeling Acidification of Groundwater. SMHI, Norrköping. 1992c

Warfvinge, P. and Sverdrup, H. Modeling regional mineralogy and weathering rates. In: Kharka, Y. and Maest, A. (Eds.), Proceedings of the 7th International Symposium on water-rock interaction, held in Utah, July 13-19, 1992, 49-53. Balkemaa Publishers. $1992 \mathrm{~d}$

Warfvinge P., and Sverdrup H. Critical loads of acidity to Swedish forest soils. Reports in Ecology and Environmental Engineering 1993;5, Lund University, Lund, Sweden, 104 pp. 1993

Warfvinge, P., Sverdrup, H., Modelling limestone dissolution in soils. Soil Science Society of America Journal, 53:44-51. 1989

Warfvinge, P., Sverdrup, H., Critical loads of acidity to Swedish forest soils, Reports in Environmental Engineering and Ecology, 5:95, 127 pp, Chemical Engineering II, Box 124, Lund University. 22100 Lund, Sweden. 1995

Warfvinge, P., Falkengren-Grerup, U., Sverdrup, H., Andersen, B. Modeling long-term cation supply in acidified forest stands. Environmental Pollution 80:209-221. 1993.

Warfvinge, P., Mörth, M., Moldan, F. What processes govern recovery? In: Recovery from Acidification in the Natural Environment: Present Knowledge and Future Scenarios. Warfvinge, P. and Bertills, U. (eds). Report 5034, Swedish Environmental Protection Agency, 23-36. 2000.

Warfvinge, P., Sverdrup, H., Alveteg, M., Rietz, F. Modelling geochemistry and lake pH since glaciation at lake Gårdsjön. Water, Air and Soil Pollution 85:713-718. 1996

Warfvinge, P., Sverdrup, H., Norrström, A.C., Jacks, G. A model for dissolution of limestone in soils and neutralization of soil systems In: Acidification and Water Pathways, N. Christophersen (Ed), 137-146, ISBN 82-554-0486-4. Norwegian National Committee for Hydrology. Bolkesjø, Norway. 1987

Warfvinge, P., Sverdrup, H., Ågren, G., Rosen, K. Effekter av luftföroreningar på framtida skogstillväxt. In: L. Svensson (Ed.) Skogspolitiken inför 2000-talet-1990 års skogspolitiska kommitte, Peer-reviewed in a public Parliamentary hearing in 1992. Statens Offentliga Utredningar; 1992 SOU: 76: 377-412. Reviewed at a public hearing in the Swedish Parliament by parliament members and Swedish scientists. 1992

Warfvinge, P., Sverdrup, H., Rosen, K. Calculating critical loads for N to forest soils. In: Grennfelt P.I. and Lövblad G., (Eds) Critical Loads and Levels for Nitrogen, 403-417. Nordic Council of Ministers. Nord 1992:41. 1992

Warfvinge, P., Sverdrup, H., Alveteg, M. and Rietz, F.: Modelling geochemistry and lake pH since glaciation at lake Gårdsjön, In: P.I. Grennfelt and J. Wisniewski (eds), Proceedings of the Acid Reign 95? Conference, Water, Air and Soil Pollution Journal, Kluwer, Amsterdam, p. 6-12. 1996,

Weissbart, E.J. and Rimstidt, J.D. Wollastonite: incongruent dissolution and leached layer formation. Geochimica et Cosmochimica Acta 64, 4007-4016. 2000

Welch, S.A. and Ullman, W.J. The effect of organic acids on plagioclase dissolution rates and stoichiometry. Geochimica et Cosmochimica Acta 57, 2725-2736. 1993

Welch, S. and Ullman, W. Feldspar dissolution in acidic and organic solutions: Compositional and pH dependence of dissolution rate. Geochimica et Cosmochimica Acta 60, 2939-2948. 1996

Welch, S.A. and Ullman, W.J. The temperature dependence of bytownite feldspar dissolution in neutral aqueous solutions of inorganic and organic ligands at low temperature $\left(5-35^{\circ} \mathrm{C}\right)$. Chemical Geology 167, 337-354. 2000

Westrich, H.R., Cygan, R.T., Casey, W.H., Zemitis, C., Arbold, G.W. The dissolution kinetics of mixed-cation orthosilicate minerals. American Journal of Science 293, 869 - 893. 1993

White A. and Brantley S.L. The effect of time on the weathering of silicate minerals: why do weathering rates differ in the laboratory and field? Chemical Geology 202, 479-506. 2003

White, A.F., S.L. Brantley. Chemical Weathering Rates of Silicate Minerals: An Overview, in Chemical Weathering Rates of Silicate Minerals A.F. White and S.L. Brantley (eds.), Mineralogical Society of America Short Course, Reviews in Mineralogy 31, 1-22. 1995.

White, A.F. and Blum, A.E. Effects of climate on chemical weathering in watersheds. Geochimica et Cosmochimica Acta 59, 17291747. 1995

White, A.F., Blum, A.E., Bullen, T.D., Vivit, D.V., Schulz, M., Fitzpatrick, J. The effect of temperature on experimental and natural chemical weathering rates of granitoid rocks. Geochimica et Cosmochimica Acta 63, 3277-3291. 1999

Whitfield, C. J., Watmough, S. A., Aherne, J., and Dillon, P. J.: A comparison of weathering rates for acid-sensitive catchments in Nova Scotia, Canada and their impact on critical load calculations, Geoderma, 136, 899-911, doi:10.1016/j.geoderma.2006.06.004. 2006

Whitfield, C.J., Phelan, J.N., Buckley, J., Clark, C.M., Guthrie, S., Lynch, J.A., Estimating Base Cation Weathering Rates in the USA: Challenges of Uncertain Soil Mineralogy and Specific Surface Area with Applications of the PROFILE Model. Water, Air and Soil Pollution 61 https://doi.org/10.1007/s11270-018-3691-7. 2018.

Whitfield, C. J., and Watmough, S. A. (2012). A regional approach for mineral soil weathering estimation and critical load assessment in boreal Saskatchewan, Canada. Science of the Total Environment, 437, 165-172. 
Whitfield, C.J., Aherne, J., Watmough, S.A.. Modeling soil acidification in the Athabasca Oil Sands Region, Alberta, Canada. Environ. Sci. Technol. 43: 5844-5850. 2009.

Whitfield, C.J., Aherne, J., Watmough, S.A., McDonald, M. Estimating the sensitivity of forest soils to acid deposition in the Athabasca Oil Sands Region, Alberta. J. Limnol. 69: 201-208. 2010

Wogelius, R.A. and Walther, J.V. Olivine dissolution at $25^{\circ} \mathrm{C}$ : effects of $\mathrm{pH}, \mathrm{CO}_{2}$, and organic acids. Geochimica et Cosmochimica Acta 55, 943-954. 1991

Wogelius, R.A. and Walther, J.V. Olivine dissolution kinetics at near-surface conditions. Chemical Geology 97, $101-112.1992$

Wolery, TJ. EQ3/6, a software package for geochemical modeling of aqueous systems. Lawrence Livermore National Laboratory Report UCRL MA-110662-PT-1. 1992.

Wolff-Boenisch, D., Gislason, S.R., Oelkers, E.H. The effect of fluoride on the dissolution rates of natural glasses at $\mathrm{pH} 4$ and $25^{\circ} \mathrm{C}$. Geochimica et Cosmochimica Acta 68, 4571-4582. 2004a

Wolff-Boenisch, D., Gislason, S.R., Oelkers, E.H., Putnis, C.V., The dissolution rates of natural glasses as a function of their composition at $\mathrm{pH} 4$ and 10.6, and temperatures from 25 to $74^{\circ} \mathrm{C}$. Geochimica et Cosmochimica Acta 68, 4843-4858. 2004b.

Wolff-Boenisch, D., Wenau, S., Gisaslon, S.R., Oelkers, E.H. Dissolution of basalts and peridotite in seawater, in the presence of ligands, and $\mathrm{CO}_{2}$ : implications for mineral sequestration of carbon dioxide. Geochimica et Cosmochimica Acta 75, 5510 5525. 2011

Wolff-Boenisch, D., Gislasson, S.R., Oelkers, E.H., The effect of crystallinity on dissolution rates and $\mathrm{CO}_{2}$ consumption capacity of silicates. Geochimica et Cosmochimica Acta 70, 858-870. 2006.

Wood, A., Anovitz, L.M., Elam, J.M., Cole, D.R. Riciputi, Benezeth, P. The effect of fulvic acid on the extent and rate of dissolution of obsidian. Ninth Annual V. M. Goldschmidt Conference 1999.

Xie, Z. and Walther, J.V. Dissolution stoichiometry and adsorption of alkali and alkaline earth elements to the acid-reacted wollastonite surface at $25^{\circ} \mathrm{C}$. Geochimica et Cosmochimica Acta 58, 2587-2598. 1994

Xiao, Y., and Lasaga, A. C., Ab initio quantum mechanical studies of the kinetics and mechanisms of silicate dissolution: $\mathrm{H}_{(}\left(\mathrm{H}_{3} \mathrm{O}^{+}\right)$ catalysis: Geochimica et Cosmochimica Acta, 58, 5379-5400. 1994a,

Xiao, Y., and Lasaga, A.C. Ab initio quantum mechanical studies of the kinetics and mechanisms of silicate dissolution: $\mathrm{OH}^{-}$catalysis: Geochimica et Cosmochimica Acta, 60, 2283-2295. 1994b

Yadaw, V.P, Sharma, T., Saxena, V.K., Dissolution kinetics of potassium from glauconitic sandstone in acid lixiviant. International Journal of Mineral Processing 60: 15-36. 2000

Yadaw, S.K., and Chakrapani, G.J., Dissolution kinetics of rock-water interactions and its implications. Current Science, $90,932-$ 938. 2006

Yang, L., and Steefel, C.I. Kaolinite dissolution and precipitation kinetics at $22^{\circ} \mathrm{C}$ and $\mathrm{pH} 4$. Geochimica et Cosmochimica Acta, 72 , 99-116. 2008 .

Yoo, K., Kim, B-S., Kim, M-S., Lee, J., Jeong, J. Dissolution of Magnesium from Serpentine Mineral in Sulfuric Acid Solution. Materials Transactions, 50, $1225-1230.2009$

Yu, L., Zanchi, G., Akselsson, C., Wallander, H., Belyazid, S. Modeling the forest phosphorus nutrition in a southwestern Swedish forest site. Ecological modelling 369:88-100. 2017.

Yu, L., Belyazid, S., Akselsson, C., van der Heijden, G., Zanchi, G. Storm disturbances in a Swedish forest—A case study comparing monitoring and modelling. Ecological Modelling 320, 102-113. 2016

Zabowski, D., Skinner, M.F., Payn, T.W., Nutrient release by weathering: implications for sustainable harvesting of PINUS radiata in New Zealand soils. New Zealand Journal of Forestry Science 37: 336-354. 2007

Zanchi, G., Belyazid, S., Akselsson, C., Yu, L. Modelling the effects of management intensification on multiple forest services: a Swedish case study. Ecological Modelling, 284, 48-59. 2017

Zanchi, G.: Modelling nutrient transport from forest ecosystems to surface waters: The model ForSAFE2D. Lund, Sweden: PhD Thesis. Lund University, Faculty of Science, Department of Physical Geography and Ecosystem Science. ISBN: 9789185793686. 2016.

Zanchi, G., Belyazid, S., Akselsson, C., Yu, L., Bishop, K., Köhler, S., Grip, H. A Hydrological Concept Including Lateral Water Flow Compatible with the Biogeochemical Model ForSAFE. Hydrology, 3, 11-28. doi:10.3390/hydrology3010011. 2016.

Zassi, Å. Chlorite: Geochemical properties, Dissolution kinetics and Ni(II) sorption. Doctoral Thesis in Chemistry KTH Chemical Science and Engineering Stockholm, Sweden, 2009

Zavodsky, D, Babiakova, G., Mitosinkova, M., Pukancikove, Roncak, P., Bodis, D., Rapant, S., Mondas, J., Skvarenina, J., Cambel, B., Rehak, S., Wathne, B., Henriksen, A., Sverdrup, H., Tørseth, K., Semb, A, Aamlid, D. Mapping critical loads/levels in the Slovak Republic. Acid Rain Research 37:1996. Niva, Oslo. 1995

Zavodsky, D, Babiakova, G., Mitosinkova, M., Pukancikove, Roncak, P., Bodis, D., Rapant, S., Mondas, J., Skvarenina, J., Cambel, B., Rehak, S., Curlik, J., Wathne, B., Henriksen, A., Sverdrup, H., Tørseth, K., Semb, A, Aamlid, D., Mulder, J. Mapping critical loads/levels in the Slovak Republic. Final report. Acid Rain Research 43:1996. Niva, Oslo.1996

Zhang, H.L., Bloom, P.R., Nater, E.A., Erich, M.S. Rates and stoichiometry of hornblende dissolution over 115 days of laboratory weathering at $\mathrm{pH} 3.6-4.0$ and $25^{\circ} \mathrm{C}$ in $0.01 \mathrm{M}$ lithium acetate. Geochimica et Cosmochimica Acta 60, $941-950.1996$

Zhang, H., Bloom, P. The pH dependence of hornblende dissolution Soil Science, 164:624-632. 1999

Zhang, H., Bloom, P. Dissolution Kinetics of Hornblende in Organic Acid Solutions. Soil Science Society of America Journal 63: 815-822. 1999

Zhang, R., Zhang, X., Guy, B., Hu, S., de Ligny, D., Moutte, J. Experimental study of dissolution rates of hedenbergitic clinopyroxene at high temperatures: dissolution in water from $25^{\circ} \mathrm{C}$ to $374^{\circ} \mathrm{C}$. Eur. J. Mineral. 25, 353-372. 2013

Zhang, L. and Lüttge, A. Al-Si order in albite and its effect on albite dissolution processes: a Monte Carlo study. American Mineralogist 92, 1316-1324. 2007

Zhang, L. and Lüttge, A. Theoretical approach to evaluating plagioclase dissolution mechanisms. Geochimica et Cosmochimica Acta 73, 2832-2849. 2009a

Zhang, L. and Lüttge, A. Morphological evolution of dissolving feldspar prticles with anisotropic surface kinetics and implication for dissoltuion rate normalizaion and grain size deendence: A kinetic modelling study. Geochimica et Cosmochimica Acta 73 , 6757-6770. 2009b

Zhu, C., and Lu, P., Alkali feldspar dissolution and secondary mineral precipitation in batch systems: 3 . Saturation states of product 
https://doi.org/10.5194/bg-2019-464

Preprint. Discussion started: 27 March 2020

Biogeosciences

(C) Author(s) 2020. CC BY 4.0 License.

minerals and reaction paths. Geochimica et Cosmochimica Acta 73: 3171-3200. 2009

Zhu, C., Lu, P., Zheng, Z. and Ganor, J. Coupled alkali feldspar dissolution and secondary mineral precipitation in batch systems: 4. Numerical modeling of kinetic reaction paths. Geochimica et Cosmochimica Acta 74, 3963-3983. 2010

Zhu, C., Blum, A.E., Veblen, D.R. Feldspar dissolution rates and clay precipitation in the Navajo aquifer at Black Mesa, Arizona, USA. In: Wanty R.B., Seal R.R.I. (eds) Water-rock interaction. August Aimé Balkema, Saratoga Springs, pp 895-899. 2004 Zysset, M., and Schindler, P.W. The proton promoted dissolution kinetics of K-montmorillonite. Geochimica et Cosmochimica Acta 60, 921-931. 1996

Öborn, I., Modin-Edman, A. K., Bengtsson, H., Gustafson, G., Salomon, E., Nilsson, S. I., Holmqvist, J., Jonsson, S., Sverdrup, H.. A Systems Approach to Assess Farm-Scale Nutrient and Trace Element Dynamics: A Case Study at the Öjebyn Dairy Farm. Ambio 34:298-308. 2005

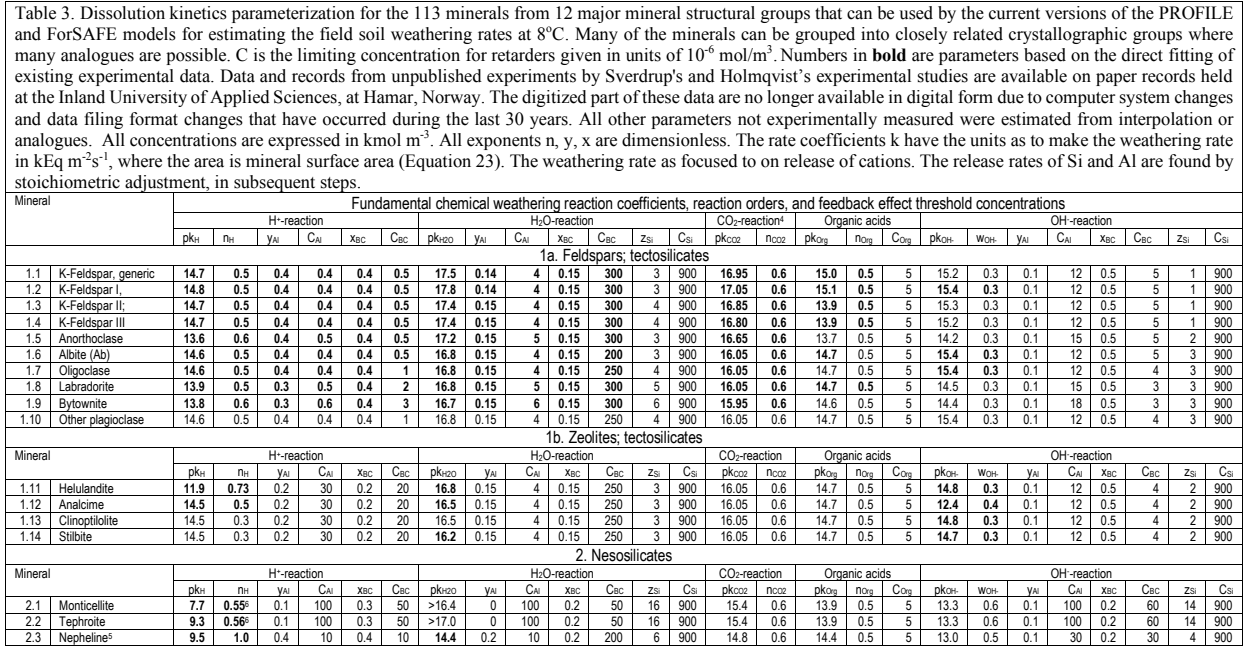

'There seems to be some type of $\mathrm{CO}_{2}$ saturation of the surface between 10 and $50 \mathrm{~atm} \mathrm{CO}_{2}$ for mica and chlorites, beyond where the rate is no more affected. Some other minerals have indications of similar behaviour, but it remains elusive in ternss of parameterizatiton. Some minerals appear to have no detectable reaction with $\mathrm{CO}_{2}$ s some are slightly inhibited.
${ }_{\mathrm{N} \text { Nepheline is classified as a feldspatiod in the mineralogical literature. However, when dissolving, the pre-dissolution complexing process at the mineral water interface create an activated surface complex with a nesosilicate }}$
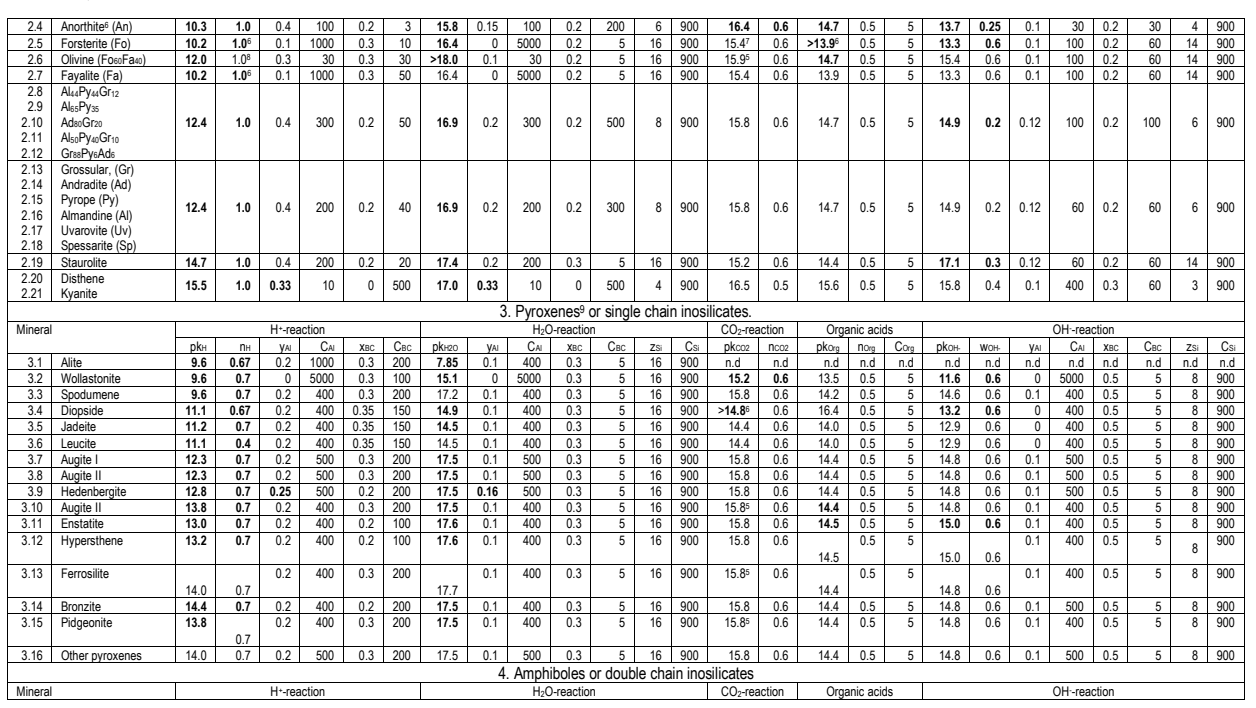

${ }^{6}$ Anorthite is classified as a feldspar in the mineralogical literature. However, when dissolving pure anorthite, the pre-dissolution complexing process at the mineral water interface create an activated surface complex with a
nesosilicate structure. This applied only to pure anorthite with less than $2 \%$ other feldspars in the solution. That is why it is listed among the nessosilicates. See Sverdrup (1990) for further details. This may be thecase with Monticellite and Tephroite as well. 
https://doi.org/10.5194/bg-2019-464

Preprint. Discussion started: 27 March 2020

(c) Author(s) 2020. CC BY 4.0 License.

Biogeosciences

Discussions

(c) (1)

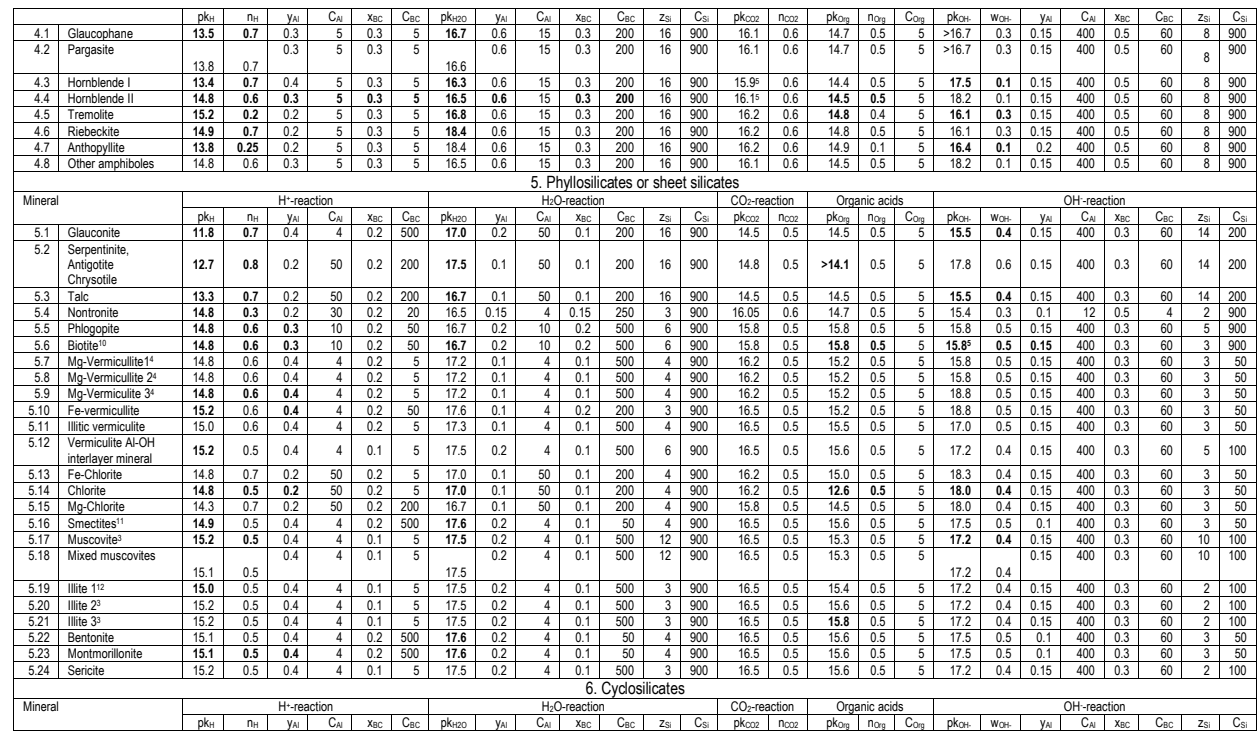

10All biotite and vermiculites have the same lattice breakdown rate (Sverdrup and Holmqvist 2004), the release rate results from the combination of lattice down kinetics and the mineral stoichiometry

Dill smectites, including montmorillonites and bentonites have the same lattice breakdown rate (Sverdrup and Holmqvist 2004), the release rate results from the combination of lattice breakdown kinetics

stoichiometry
${ }^{1}$ All muscovite and illites have the same lattice breakdown rate (Sverdrup and Holmqvist 2004), the release rate results from the combination of lattice breakdown kinetics and the mineral stoichiometry.

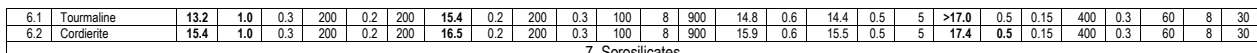

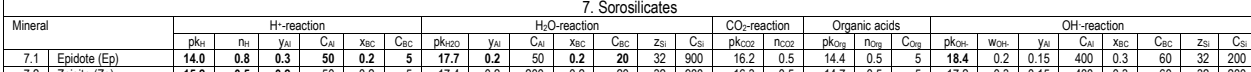

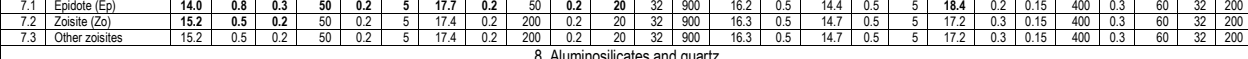

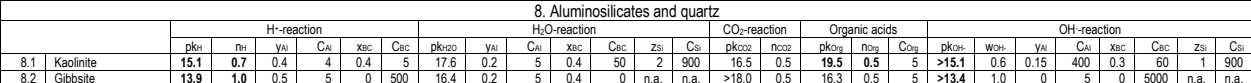

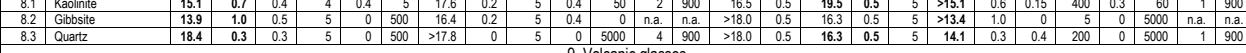

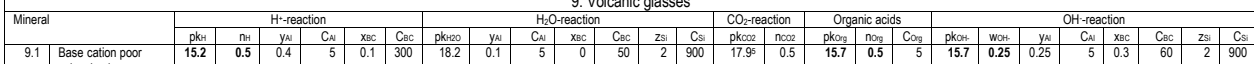

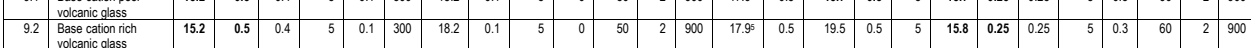

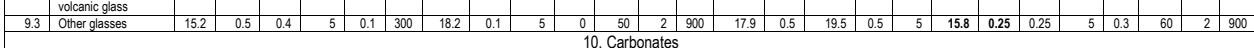

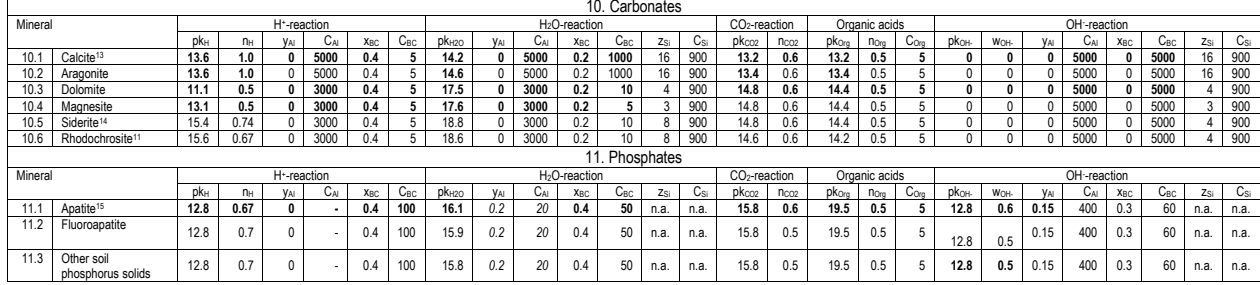

13This is a general calcite. Accurate kinetic data are available for 8 different Swedish and 6 different American commercially available calcites, and 4 different Swedish, English, Finnish and Estonian dolomites (See Sverdrup an

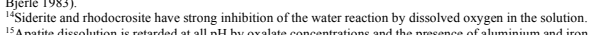


https://doi.org/10.5194/bg-2019-464

Preprint. Discussion started: 27 March 2020

Biogeosciences

(c) Author(s) 2020. CC BY 4.0 License.

Discussions

(c) (1)

2068
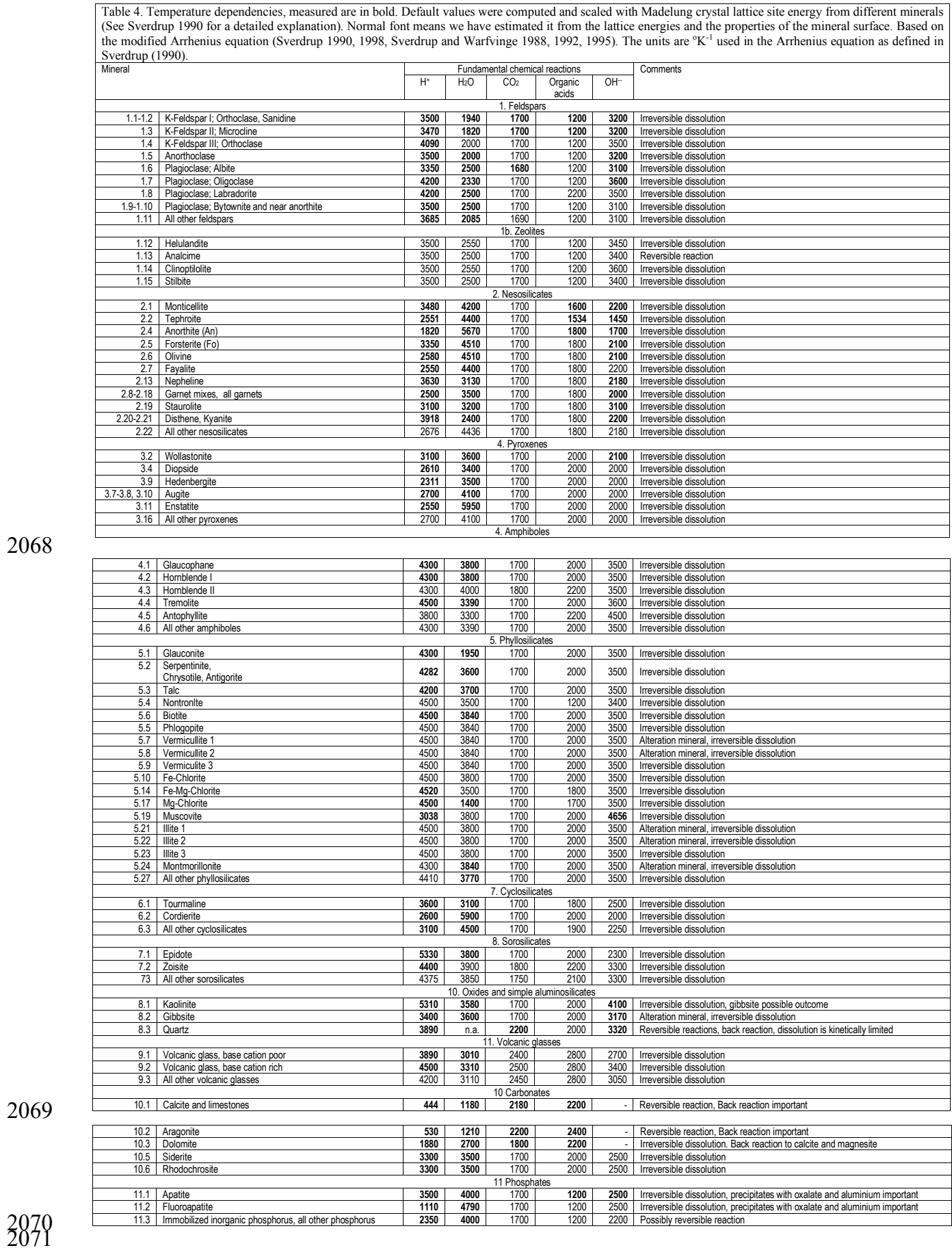
https://doi.org/10.5194/bg-2019-464

Preprint. Discussion started: 27 March 2020

Biogeosciences

(c) Author(s) 2020. CC BY 4.0 License.

Discussions

(c)

\begin{tabular}{|c|c|c|c|}
\hline & & Table 5. Stoichion & try of the minerals applied in Tables 3 and 4. \\
\hline & & & 1a. Feldspars \\
\hline & & Mineral & Formula \\
\hline & 1.1 & K-Feldspar & $\mathrm{KAlSi}_{3} \mathrm{O}_{8}=\mathrm{Or}_{\mathrm{r}}$ \\
\hline & 1.2 & K-Feldspar I; Orthoclase, K-Feldspar I; Sanidine, 100-90\% & 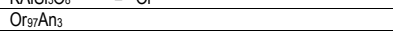 \\
\hline & 1.3 & K-Feldspar Il; 90\%, Microcline & $\mathrm{Or}_{9} \mathrm{Ab}_{2} \mathrm{An}_{1}$ \\
\hline & $\frac{1.4}{1.4}$ & K-Feldspar II; $80 \%$, Orthoclase & $\mathrm{Or}_{80} \mathrm{~A}_{20}$ \\
\hline & 1.5 & Anorthoclase & $\mathrm{Or}_{22} \mathrm{Ab}_{22} \mathrm{An}_{17}$ \\
\hline & 1.6 & \begin{tabular}{|l|l} 
Albite \\
\end{tabular} & $\mathrm{NaAlSi}_{3} \mathrm{O}_{8}=\mathrm{Ab}$ \\
\hline & $\frac{1.0}{1.7}$ & \begin{tabular}{|l|} 
Plagioclase; Oligoclase \\
\end{tabular} & 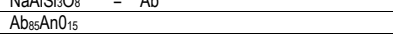 \\
\hline & $\frac{1.1}{1.8}$ & \begin{tabular}{|l} 
Plagiociase, ingocilase \\
Plagioclase; Labradorite
\end{tabular} & 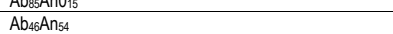 \\
\hline & 1.9 & \begin{tabular}{|l|l|} 
Plagioclase; Bytownite \\
\end{tabular} & $A b_{22} A_{78}$ \\
\hline & 1.10 & Plagioclase; feldparic Anorthite & \begin{tabular}{|l|l|l} 
AdbeAnng4 \\
\end{tabular} \\
\hline & & 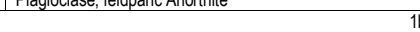 & Zeobilites with tectosilicate structure \\
\hline & 1.12 & Helulandite & $(\mathrm{Ca}, \mathrm{Na})_{0.45} \mathrm{Al}_{0.89} \mathrm{Si}_{3}, 108 \cdot 2.7 \mathrm{H}_{2} \mathrm{O}$ \\
\hline & 1.13 & Analcime & $\mathrm{NaAlS} \mathrm{S}_{2} \mathrm{O}_{6} \cdot \mathrm{H}_{2} \mathrm{O}$ \\
\hline & 1.14 & \begin{tabular}{|l} 
Mlanumitlitite \\
Clinotion
\end{tabular} & 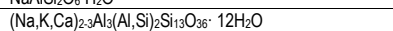 \\
\hline & $\frac{1.15}{1.15}$ & Stilibite & 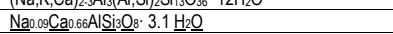 \\
\hline & & & 2. Nesosilicates \\
\hline & 2.1 & \begin{tabular}{|l|l} 
Monticellite \\
Tonhoite
\end{tabular} & $\mathrm{CaMgSiO}_{4}$ \\
\hline & 2.2 .2 & Tephoite & \begin{tabular}{|l|l}
$\mathrm{Mn}_{2} \mathrm{Si}_{4}$ \\
\end{tabular} \\
\hline & 2.3 & Nepheline & 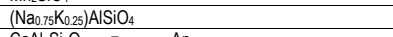 \\
\hline & 2.4 & Anorthite & $\mathrm{CaA}_{2} \mathrm{~S}_{2} \mathrm{O}_{8}=\mathrm{An}$ \\
\hline & 2.5 & \begin{tabular}{|l|l|} 
Forsterite \\
\end{tabular} & $\mathrm{Mg}_{2} \mathrm{SiO}_{4}$ \\
\hline & 2.6 & $\begin{array}{l}\text { San Carlos, Arizona Forsterite } \\
\text { Salem, Tamil Nadu Indian olivine }\end{array}$ & 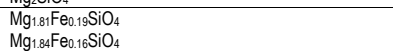 \\
\hline & & Norwegian Olivine (Fo65Fas5) & $\mathrm{Mg}_{1.5} \mathrm{Fe}_{0.35} \mathrm{Al}_{0.02} \mathrm{Si}_{1.04} \mathrm{O}_{4}$ \\
\hline & 2.7 & Fayalite & $\mathrm{Fe}_{2} \mathrm{SiO}_{4}$ \\
\hline & $2.8-2.12$ & Generic garnet, continuous series & 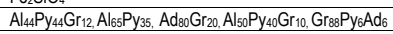 \\
\hline & 2.13 & Grossular & $\mathrm{Ca}_{3} \mathrm{Al}_{2}\left(\mathrm{SiO}_{4}\right)_{3} ;$ \\
\hline 2072 & 2.14 & Almandine $=\mathrm{Al}$ & \begin{tabular}{|l}
$\mathrm{Fe}_{3} \mathrm{Al}_{2}\left(\mathrm{SiO}_{4}\right)_{3}$ \\
\end{tabular} \\
\hline & 2.15 & Spessartine $=\mathrm{Sp}$ & ${\mathrm{Mn} 3 \mathrm{Al}_{2}\left(\mathrm{SiO}_{4}\right)_{3}}$ \\
\hline & $\frac{2.15}{2.16}$ & $\begin{array}{l}\text { Spessadure }-\mathrm{sp} \\
\text { Andradite }=\mathrm{Ad}\end{array}$ & 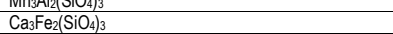 \\
\hline & $\frac{2.10}{2.17}$ & $\begin{array}{l}\text { Anaradile }=\mathrm{Ad} \\
\text { Uvarovite }=U \mathrm{v}\end{array}$ & \begin{tabular}{|l}
$\left.\mathrm{Ca}_{3} \mathrm{C}_{2} \mathrm{Cr}_{2}\left(\mathrm{SiO}_{4}\right)_{3}\right)_{3}$ \\
\end{tabular} \\
\hline & 2.18 & Pyrope $=$ Py & $\mathrm{Mg}_{3} \mathrm{Al}_{2}\left(\mathrm{SiO}_{4}\right)_{3}$ \\
\hline & $\frac{2.18}{2.19}$ & \begin{tabular}{|l} 
Pyrope $=$ Sy \\
Staurolite
\end{tabular} & 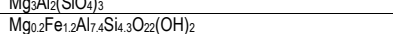 \\
\hline & $\frac{2.19}{2.20}$ & \begin{tabular}{|l} 
Diasthene \\
\end{tabular} & 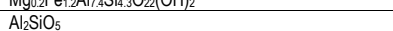 \\
\hline & 2.21 & 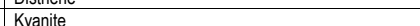 & \begin{tabular}{|lll}
$\mathrm{A}_{2} 2 \mathrm{U}_{5}$ \\
$\mathrm{Al}_{2} \mathrm{SiO}_{5}$ \\
\end{tabular} \\
\hline & & 2.223. Pyroxenes (End & embers are diopside, hedenbergite, enstatite, ferrosillite) \\
\hline & 3.1 & Alite (T-slag, K-slag) & $\mathrm{Ca}_{3} \mathrm{SiO}_{5}$ or $(\mathrm{CaO})_{3} \mathrm{SiO}_{2}$ \\
\hline & 3.2 & Wollastonite $\left(\mathrm{Ca}_{22} 2 \mathrm{~S}_{2} \mathrm{O}_{6}\right)$ & $\mathrm{Ca}_{1.7} \mathrm{Mgg}_{0.11} \mathrm{Si}_{22} \mathrm{O}_{6}$ \\
\hline & 3.3 & Spodumene $\left(\mathrm{LiAlS}_{\mathrm{A}} \mathrm{O}_{6}\right)$ & LiAllo.86 $\mathrm{Fe}_{0.3 \mathrm{~S}} \mathrm{Si}_{2} \mathrm{O}_{6}$ \\
\hline & 3.4 & Diopside $\left(\mathrm{CaMgSi}_{2} \mathrm{O}_{6}\right)$ & 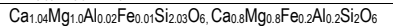 \\
\hline & 3.5 & Jadeite (NaAlSi2 $2_{6}$ ) & $\mathrm{Na}_{1.0} \mathrm{Ca}_{0.2} \mathrm{Fe}_{0.3} \mathrm{AlSi}_{2} \mathrm{O}_{6}$ \\
\hline & 3.6 & Leucite $\left(\mathrm{KAISi}_{2} \mathrm{O}_{6}\right)$ & $N a_{0.05} \mathrm{~K}_{1.009} \mathrm{Al}_{1.15} \mathrm{Si}_{2.3} \mathrm{O}_{6}$ \\
\hline & 3.7 & Augite I & $\mathrm{He}_{55} \mathrm{En}_{45}$ \\
\hline & 3.8 & Augite II & En $_{51} W_{03} \mathrm{He}_{10}$ \\
\hline & 3.9 & Hedebergite $\left(\mathrm{CaFeSi}_{2} \mathrm{O}_{6}\right)$ & 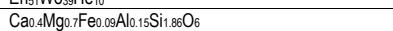 \\
\hline & 3.10 & Augite III & 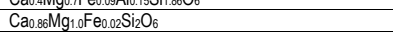 \\
\hline & 3.11 & Enstatite $\left(\mathrm{Mg}_{2} \mathrm{Si}_{2} \mathrm{O}_{6}\right)$ & $\mathrm{Mg}_{1.7} \mathrm{Fe}_{0.3} \mathrm{Si}_{2} \mathrm{O}_{6}$ \\
\hline & 3.12 & \begin{tabular}{|l|} 
Hypersthene \\
\end{tabular} & $\mathrm{MgFeSi}_{2} \mathrm{O}_{6}$ (Ens5 \\
\hline & $\frac{0.12}{3.13}$ & $\begin{array}{l}\text { Myperstrente } \\
\text { Ferrosilite }\end{array}$ & 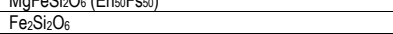 \\
\hline & $\frac{0.15}{3.14}$ & \begin{tabular}{|l|l|} 
Bronzite (mixed) \\
\end{tabular} & 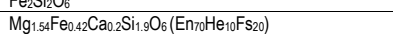 \\
\hline & $\frac{3.14}{3.15}$ & \begin{tabular}{|l|l} 
Bronzle (mixea) \\
Pidgeonite
\end{tabular} & 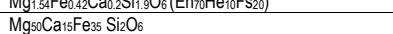 \\
\hline & 3.16 & Mixed pyroxenes & 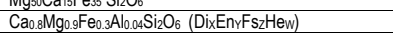 \\
\hline & & & 4. Amphiboles \\
\hline & 4.1 & Glaucophane & $\mathrm{Na}_{2} \mathrm{MgFe}_{2} \mathrm{Al}_{2} \mathrm{Si}_{8} \mathrm{O}_{22}(\mathrm{OH})_{2}$ \\
\hline & 4.2 & Pargasite & $\mathrm{NaCa}_{2}\left(\mathrm{Mg}_{4} \mathrm{Al}\right)\left(\mathrm{Si}_{i} \mathrm{Al}_{2}\right) \mathrm{O}_{22}(\mathrm{OH})_{2}$ \\
\hline & 4.3 & Hornblende I (Norwegian) & 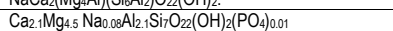 \\
\hline & 4.4 & Hornblende II (Canadian) & 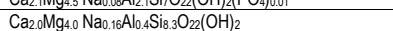 \\
\hline & $\frac{4.4}{4.5}$ & \begin{tabular}{|l|l|l} 
Tremolite \\
\end{tabular} & $\mathrm{Ca}_{2} \mathrm{Mg}_{5} \mathrm{~S}_{\mathrm{Si}} \mathrm{O}_{22}(\mathrm{OH})_{2}$ \\
\hline & 4.6 & Riebeckite & $\mathrm{Na}_{2} \mathrm{Fe}^{2+3} \mathrm{Fe}^{3+2} \mathrm{Si}_{18} \mathrm{O}_{22}(\mathrm{OH})_{2}$ \\
\hline & 4.7 & Anthophyllite & 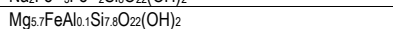 \\
\hline & 4.8 & Other amphiboles & \begin{tabular}{|l|} 
Various compositions \\
\end{tabular} \\
\hline & & & 5. Phyllosilicates \\
\hline & 5.1 & Glauconite & $\left.(\mathrm{K}, \mathrm{Na})\left(\mathrm{Fe}^{3+}, \mathrm{A}, \mathrm{Mg}\right)_{2}(\mathrm{Si}, \mathrm{A})_{4}\right)_{10}(\mathrm{OH})_{2}$ \\
\hline & 5.2 & Serpentine, Antigorite, Chrysotile & $\mathrm{Mg}_{4} \mathrm{Fe}_{0.4} \mathrm{Al}_{1.15} \mathrm{Si}_{2.8} \mathrm{O}_{10}(\mathrm{OH})_{4} \quad\left(\mathrm{Mg}_{2}, \mathrm{Fe}\right)_{3} \mathrm{Si}_{2} \mathrm{O}_{5}(\mathrm{OH})_{4}$ \\
\hline & 5.3 & Talc & $\mathrm{Mg}_{28} \mathrm{Fe}_{0.18} \mathrm{Si}_{4} 0_{10}(\mathrm{OH})_{3}$ \\
\hline & 5.4 & Nontronite & $\mathrm{Ca} .5\left(\mathrm{Si}_{i} \mathrm{Al} .8 \mathrm{Fe}_{2}\right)\left(\mathrm{Fe}_{3.5 \mathrm{Al}} . \mathrm{Mq}_{1 .}\right) \mathrm{O}_{20}(\mathrm{OH})_{4}$ \\
\hline & 5.5 & \begin{tabular}{|l|l} 
Phlogopite \\
\end{tabular} & $\mathrm{K}_{1.0} \mathrm{Mg}_{3} \mathrm{Al}_{1.0} \mathrm{O} \mathrm{i}_{3} \mathrm{O}_{10}(\mathrm{OH})_{2}$ \\
\hline & 5.6 & Biotite & 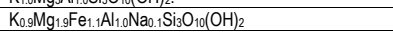 \\
\hline
\end{tabular}


https://doi.org/10.5194/bg-2019-464

Preprint. Discussion started: 27 March 2020

Biogeosciences

(C) Author(s) 2020. CC BY 4.0 License.

Discussions

(c) (1)

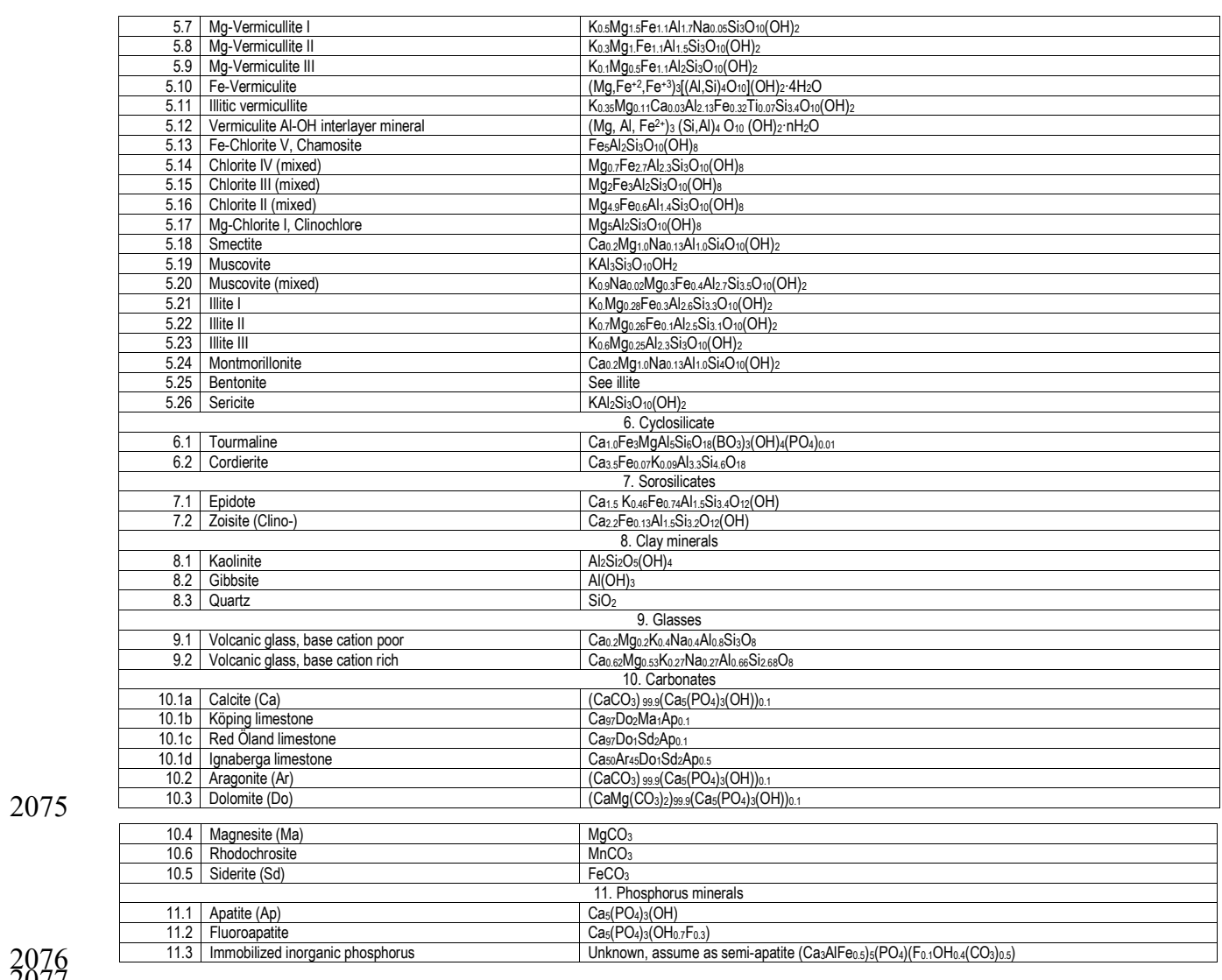


https://doi.org/10.5194/bg-2019-464

Preprint. Discussion started: 27 March 2020

(c) Author(s) 2020. CC BY 4.0 License.

\section{Appendix. Overview of the PROFILE family of weathering rate modelling codes}

A large number of computational weathering models are based on PROFILE approach. To clarify these models and their interconnections the following list is provided

\section{Steady-state weathering rate models}

a. 1987-1995; Warfvinge P. and Sverdrup, H.; The single site version of the PROFILE model for the calculation and mapping of critical loads and rates of field chemical weathering was developed. It has been validated and used operationally in more than 50 countries worldwide. It uses laboratory generated kinetic models and coefficients to predict field weathering rates. The interface software for PROFILE became outdated, thus, this version is no longer available.

b. 1992-present; Sverdrup, H., Warfvinge, P., Alveteg, M., Walse, C., Kurz, P., Posch, M., Belyazid, S.; The code RegionaIPROFILE was developed. This code is a regionalized version of PROFILE, used for creating weathering rate maps for soils and catchments across regions and countries, as well as to estimate critical loads for forest soils. Updated versions of the code are available upon request from Sverdrup, Akselsson or Belyazid.

c. 2000; Sverdrup, H. and Alveteg, M., The CLAY-PROFILE code was developed. This model was made for volcanic and clayey agricultural soils. This code is no longer operable. Archived, the code is available upon written request from Sverdrup or Belyazid.

\section{Dynamic weathering models}

a. 1987-2008; Warfvinge P., Sverdrup, H., Alveteg, M., Walse, C., Martinsson, L.: The SAFE model and its helper routine MakeDep were created. SAFE is a generally applicable dynamic soil chemistry and acidification model. This tool is used worldwide for acidification research, forest sustainability assessments and for mapping critical loads.

b. 1995-1996; Rietz, F., Sverdrup, H., Warfvinge, P.; The SkogsSAFE model was developed. This long-term dynamic model simulates soil genesis, mineralogy dynamics, soil chemistry and base cation release from chemical weathering in soils over time since the most recent glaciation $(14,000$ years ago to present) (Rietz 1995, Warfvinge et al., 1996). This code is written in FORTRAN. This code and its databases are available upon written request from Sverdrup.

c. 1996-2004; Sverdrup, H., Wallman P., Belyazid, S., Alveteg, M., Walse, C., Martinsson, L.: These scientists developed ForSAFE, an integrated biogechemical forest ecosystem model for growth, nitrogen and carbon cycling. This code is written in FORTRAN code, and the code is available upon written request from Sverdrup or Belyazid.

\section{Regional mineralogy estimation}

a. 1990; Sverdrup, H., Melkerud, P. A., Kurz, D.: The UPPSALA model was developed for the reconstruction of soil mineralogy from soil total analysis data. This model is run in a spreadsheet. It is available upon written request from Sverdrup.

b. 1998; Sverdrup, H. and Erdogan, B. The Turkey mineral depletion model (TMD) was developed. This model estimates soil mineralogy from bedrock geology and estimates of soil age. This code is written in STELLA ${ }^{\circledR}$. It is archived and available upon written request from Sverdrup.

c. 2005-2010; Posch, M., Kurz, D., Alveteg, M., Akselsson, C., Eggenberger, U., Holmqvist, J; 2007 A2M, a model to quantify mineralogy from geochemical analyses was developed. This code is available on-line from doi:10.1016/j.cageo.2006.08.007, https://dl.acm.org/citation.cfm?id=1231715or from Kurz or Akselsson (Posch et al., 2006, 2007).

These models are not commercial products. They do not have ready-made handbooks (only the early single site PROFILE models had a good users interface and a user's manual). The models are available, but the best option to learn how to run these get training from the contact scientists in how to operate the models and how to set up the input data for a site or a region. The core code is written in FORTRAN 